\title{
Temperature Profiles and Hydrologic Implications from the Nevada Test Site Area
}

\author{
prepared by \\ David Gillespie
}

\author{
submitted to \\ Nevada Site Office \\ National Nuclear Security Administration \\ U.S. Department of Energy \\ Las Vegas, Nevada
}

March 2005

\section{Publication No. 45211}


Reference herein to any specific commercial product, process, or service by trade name, trademark, manufacturer, or otherwise, does not necessarily constitute or imply its endorsement, recommendation, or favoring by the United States Government or any agency thereof or its contractors or subcontractors. The views and opinions of authors expressed herein do not necessarily state or reflect those of the United States Government or any agency thereof.

This report has been reproduced directly from the best available copy.

Available for sale to the public, in paper, from:

U.S. Department of Commerce

National Technical Information Service

5285 Port Royal Rd.

Springfield, VA 22161

phone: 800.553.6847

fax: 703.605.6900

email: order@ntis.gov

online ordering: http://www.osti.gov/ordering.htm

Available electronically at http://www.doe.gov/bridge

Available for a processing fee to the U.S. Department of Energy and its contractors, in paper, from:

U.S. Department of Energy

Office of Scientific and Technical Information

P.O. Box 62

Oak Ridge, TN 37831-0062

phone: 865.576.8401

fax: 865.576.5728

email: reports@adonis.osti.gov 


\title{
Temperature Profiles and Hydrologic Implications from the Nevada Test Site Area
}

\author{
prepared by \\ David Gillespie \\ Division of Hydrologic Sciences \\ Desert Research Institute \\ University and Community College System of Nevada
}

Publication No. 45211

\author{
submitted to \\ Nevada Site Office \\ National Nuclear Security Administration \\ U.S. Department of Energy \\ Las Vegas, Nevada
}

March 2005

The work upon which this report is based was supported by the U.S. Department of Energy under Contract \#DE-AC52-00NV13609. Approved for public release; further dissemination unlimited. 



\section{ABSTRACT}

Groundwater temperature is sensitive to the competing processes of heat flow from below and the advective transport of heat by groundwater flow. Because groundwater temperature is sensitive to conductive and advective processes, groundwater temperature may be utilized as a tracer to further constrain the uncertainty of predictions of advective radionuclide transport models constructed for the Nevada Test Site (NTS). Since heat transport, geochemical, and hydrologic models for a given area must all be consistent, uncertainty can be reduced by excluding those models that do not match estimated heat flow.

The initial objective of this study was to identify the quantity and quality of available heat flow data at the NTS. Although thousands of temperature logs have been conducted at the NTS, most are recorded on paper and not easily examined. Therefore, only those temperature logs in digital format were considered. During the course of an earlier investigation, 145 temperature logs from 63 boreholes on the NTS were examined. Of these, 13 boreholes were found to have temperature profiles suitable for the determination of heat flow values from one or more intervals within the boreholes. The successful analysis of the initial 13 temperature profiles led to the acquisition of an additional 21 temperature profiles from boreholes at the NTS, during fiscal year (FY) 2003. Five of these 21 temperature profiles were obtained in boreholes that had been previously profiled and were collected to ensure the previously collected profiles were representative of ambient conditions. The other 16 profiles were obtained in boreholes that had not been previously profiled. Additionally, a previously measured temperature profile (borehole UE-18t) that was overlooked in the initial investigation of existing temperature profiles from the NTS was discovered, and borehole PM-1 was relogged during an operational check of a new wireline for DRI's geophysical logging unit. During FY04, an additional 15 temperature profiles were obtained. Five of the temperature profiles were obtained in boreholes that had been previously profiled. The other 10 profiles were measured in boreholes from which previous stabilized temperature profiles had not been obtained.

The subject of this report is the presentation and analysis of the 13 original temperature profiles reported in 2002, as well as the subsequently collected 18 temperature profiles collected during FY 2003, and the 14 profiles collected during FY 2004. Also included are three temperature profiles from Underground Test Area program borehole ER-5-4\#2 obtained during FY 2003 and one from FY 2004, which are examined to evaluate the thermal recovery of a newly constructed borehole.

Interpretation of a temperature profile in a lithology without major variations in thermal conductivity may be fairly straightforward; interpretation of a temperature profile crossing several hydrostratigraphic units requires accurate knowledge of the thermal properties of the corresponding hydrostratigraphic units, and is complicated if advective heat transport is occurring.

Heat flow values for intervals contained within the boreholes ranged from a low of $5.0 \mathrm{~mW} \mathrm{~m}^{-2}$ to a high of $181.6 \mathrm{~mW} \mathrm{~m}^{-2}$. Vertical variations in heat flow values, within individual boreholes, were readily explained by the advection of heat by groundwater flow. Horizontal consistencies and variations in heat flow values between various boreholes were dependent upon the geologic setting of the borehole, and the effect of vertical fluid movement. 


\section{ACKNOWLEDGEMENTS}

The author wishes to acknowledge George Juniel for his assistance in providing digital temperature profiles from Bechtel geophysical log archives at the NTS. The author would also like to acknowledge Jackie Kenneally, Brad Lyles, and Todd Mihevc, for providing temperature profiles from various boreholes at the NTS, obtained during previous investigations; and to Chuck Russell and Marjory Jones for their review and comments on the manuscript. Dee Donithan and Scott Campbell were instrumental in obtaining the temperature profiles conducted specifically for this investigation. The author would also like to thank the U.S. Department of Energy (DOE) and the DOE Underground Test Area project manager, Bob Bangerter, for providing funding to accomplish the work described herein. 


\section{CONTENTS}

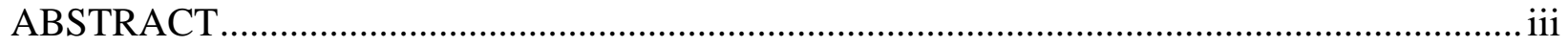

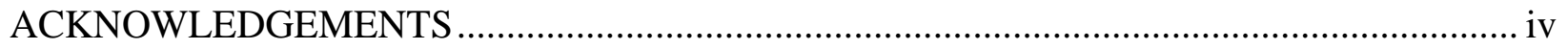

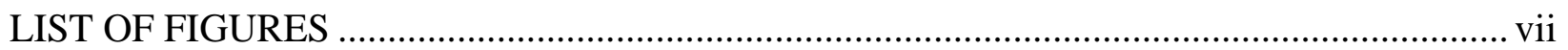

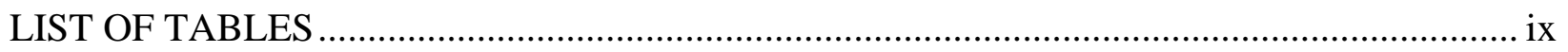

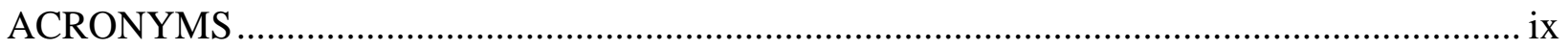

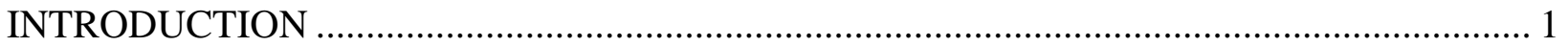

BASIC HEAT FLOW TERMS ……………………………………………………..... 1

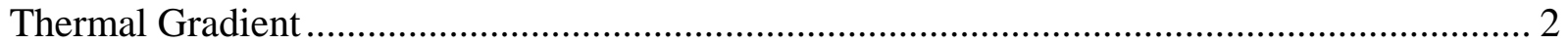

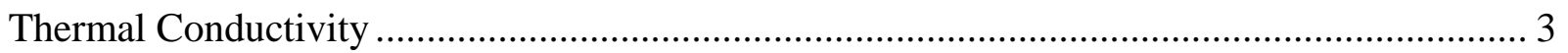

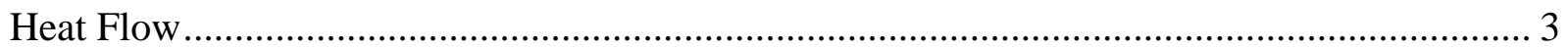

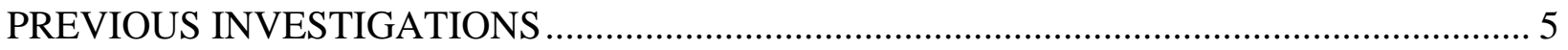

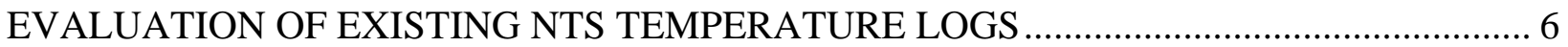

COLLECTION OF NEW TEMPERATURE DATA FROM NTS BOREHOLES........................... 9

THERMAL CONDUCTIVITY VALUES FOR NTS LITHOLOGIES......................................... 12

DISCUSSION OF WELL CONSTRUCTION, TEMPERATURE PROFILES, AND

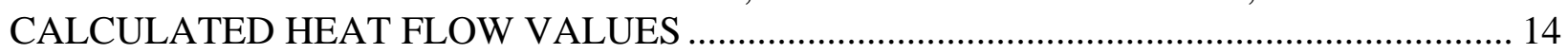

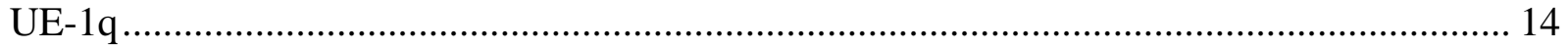

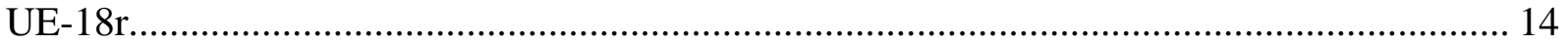

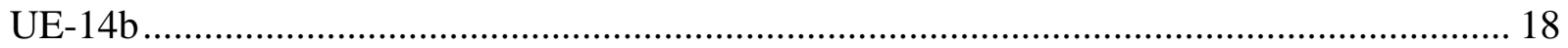

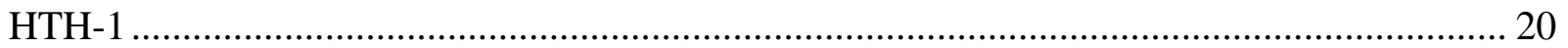

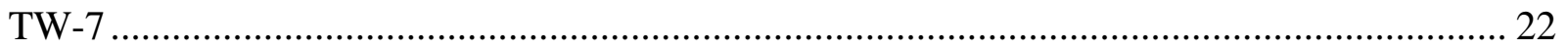

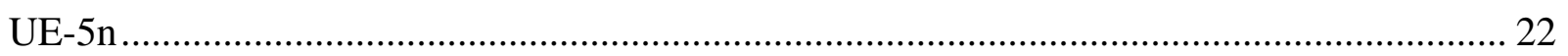

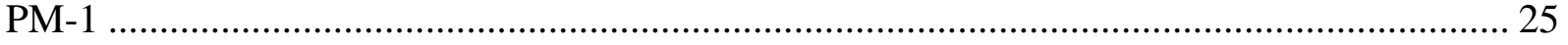

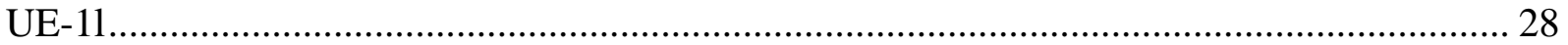

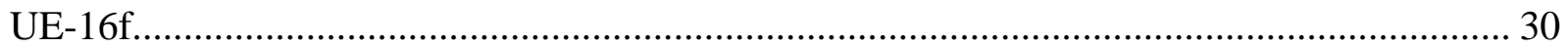

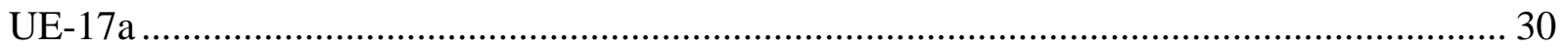

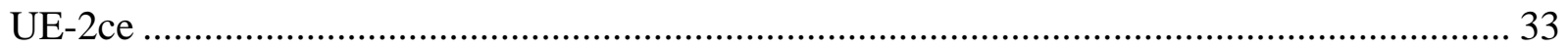

Amargosa Test Hole \#1 and Amargosa Test Hole \#2............................................................. 33

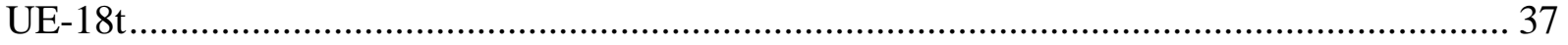

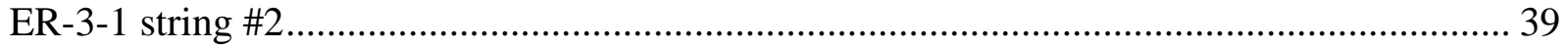

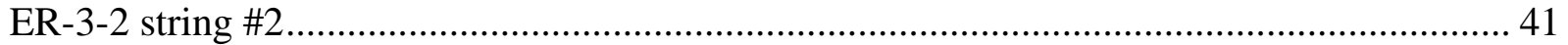

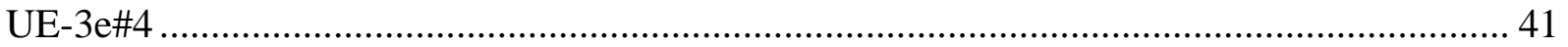




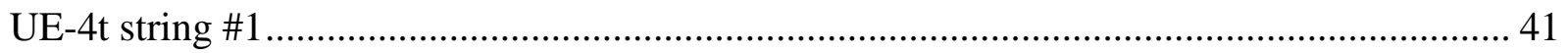

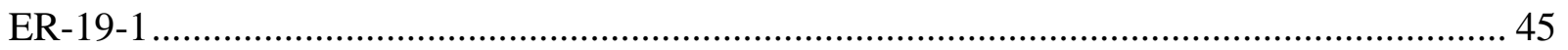

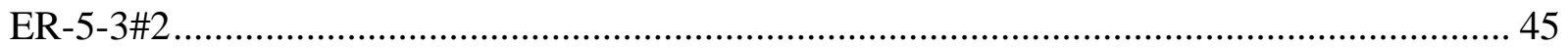

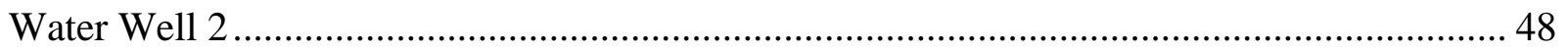

U-20 Water Well ...................................................................................................... 48

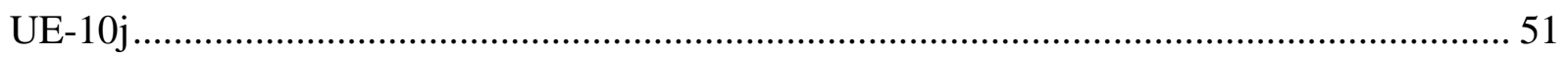

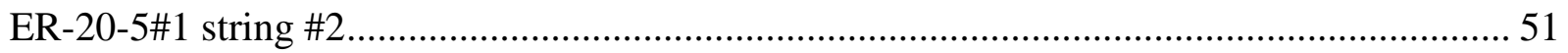

ER-20-6\#1 string \#2, ER-20-6\#2 string \#2, and ER-20-6\#3 string \#2 ................................... 54

ER-OV-03c, ER-OV-06a, and ER-OV-03a2 ............................................................. 54

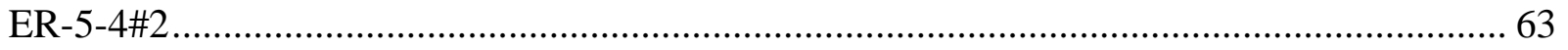

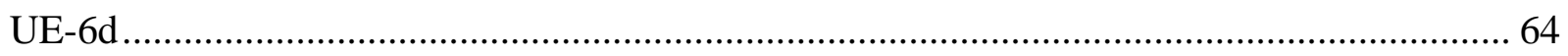

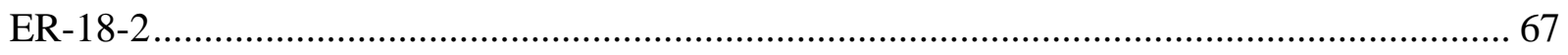

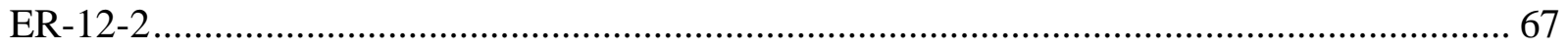

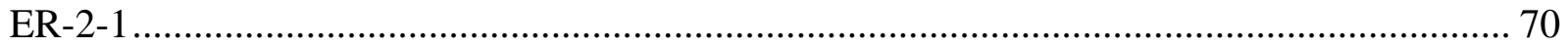

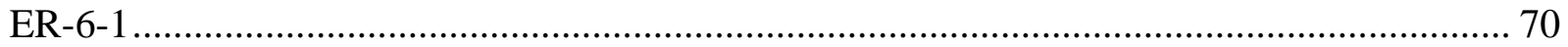

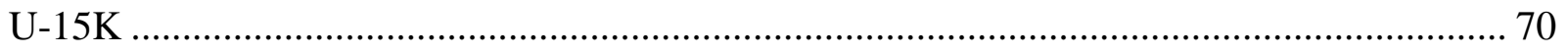

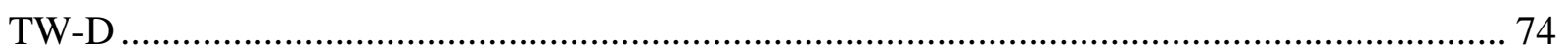

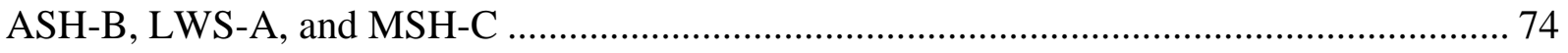

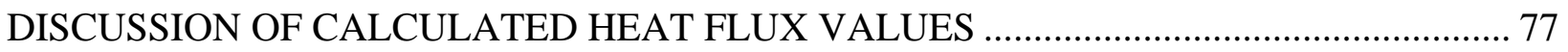

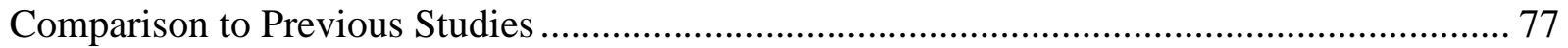

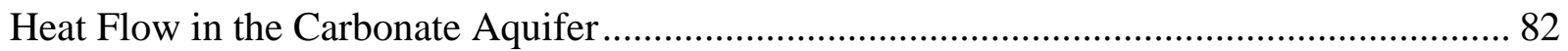

Heat Flow and Low Thermal Conductivity Lithologies ................................................. 83

Spatial Variability of Heat Flow Values .......................................................................... 83

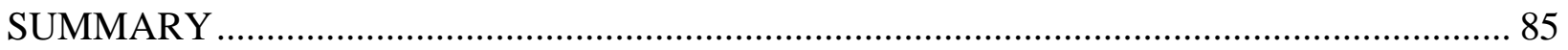

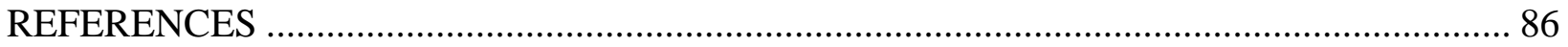

APPENDIX: TEMPERATURE DATA, BOREHOLE CONSTRUCTION, AND LITHOLOGIC INFORMATION FOR SELECTED NTS BOREHOLES 


\section{LIST OF FIGURES}

1. Relationship between temperature, thermal gradient, thermal conductivity, and heat flow in a purely conductive thermal regime..................................................................................... 4

2. Location of boreholes on, or near, the NTS with previously existing temperature logs examined in this investigation. ............................................................................................. 7

3. Location of boreholes on, or near, the NTS determined to have existing temperature profiles suitable for the determination of heat flow values.

4. Location of boreholes on, or near, the NTS that were temperature logged during FY 2003 as part of this investigation.

5. Location of boreholes on, or near, the NTS that were temperature logged during FY 2004 as part of this investigation.

6. Field calibration results for DRI's PHASe temperature probe using NIST digital thermometer.

7. Laboratory measured thermal conductivity values $\left(\mathrm{W} \mathrm{m}^{-1} \mathrm{C}^{-1}\right)$ for Tertiary volcanic lithologies (Sass et al., 1987)........................................................................................... 12

8. Temperature profiles, lithology, and well construction for borehole UE-1q........................ 15

9. Temperature profiles from UE-18r obtained by Atlas Wireline Services on March 13, 1993, and DRI on August 31, 1994, and May 20, 2004..................................... 16

10. Cross plot of temperature values from DRI's Chemtool and Atlas Wireline Services temperature profiles obtained in UE-18r approximately 1 year and 5 months apart............ 18

11. Temperature profiles, lithology, and well construction for borehole UE-14b....................... 19

12. Temperature profiles, lithology, and well construction for borehole HTH-1........................ 21

13. Temperature profiles, lithology, and well construction for borehole TW-7 ......................... 23

14. Temperature profiles, lithology, and well construction for borehole UE-5n........................ 24

15. Temperature profiles, lithology, and well construction for borehole PM-1....................... 26

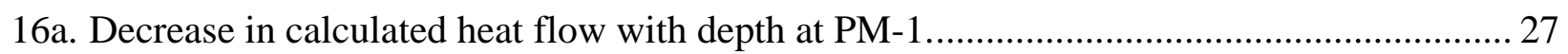

16b. Increase in thermal conductivity with depth for volcanic lithologies (Sass et al., 1987)..... 28

17. Temperature profile, lithology, and well construction for borehole UE-1l.......................... 29

18. Temperature profile, lithology, and well construction for borehole UE-16f........................ 31

19. Temperature profiles, lithology, and well construction for borehole UE-17a........................ 32

20. Temperature profile, lithology, and well construction for borehole UE-2ce......................... 34

21. Temperature profile, lithology, and well construction for borehole Amargosa Test

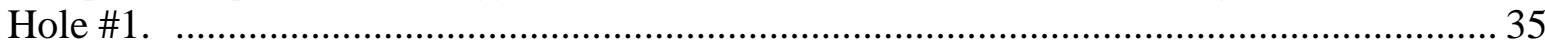

22. Temperature profile, lithology, and well construction for borehole Amargosa Test Hole \#2.

23. Comparison of UE-18t temperature profiles obtained by LLNL on August 31, 1994,

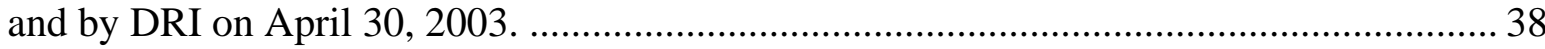

24. Temperature profile, lithology, and well construction for borehole ER-3-1 string \#2......... 40

25. Temperature profile, lithology, and well construction for borehole ER-3-2 string \#2 ......... 42

26. Temperature profile, lithology, and well construction for borehole UE-3e\#4 string \#1. ..... 43 
27. Temperature profile, lithology, and well construction for borehole UE-4t string \#1........... 44

28. Temperature profile, lithology, and well construction for borehole ER-19-1 string \#1 ....... 46

29. Temperature profile, lithology, and well construction for borehole ER-5-3 string \#2......... 47

30. Temperature profile, lithology, and well construction for borehole Water Well 2. ............. 49

31. Temperature profile, lithology, and well construction for borehole U-20 Water Well. ........50

32. Temperature profile, lithology, and well construction for borehole UE-10j........................ 52

33. Temperature profile, lithology, and well construction for borehole ER-20-5\#1 string \#2... 53

34a. Temperature profile, lithology, and well construction for borehole ER-20-6\#1 string \#2... 55

34b. Temperature profile, lithology, and well construction for borehole ER-20-6\#2 string \#2... 56

34c. Temperature profile, lithology, and well construction for borehole ER-20-6\#3 string \#2. .. 57

35a. Temperature profile, lithology, and well construction for borehole ER-OV-03c.................. 58

35b. Location of ER-OV-03c in narrow channel of Beatty Wash. ................................................. 59

36a. Temperature profile, lithology, and well construction for borehole ER-OV-03a2.................6 60

36b. Location of ER-OV-03a2 near Goss Spring (note evaporative salts on soil surface)............ 61

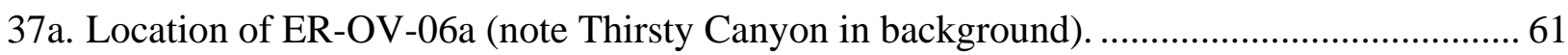

37b. Temperature profile, lithology, and well construction for borehole ER-OV-06a................... 62

38. Temperature profiles, lithology, and well construction for borehole from ER-5-4\#2...........65

39. Temperature profile, lithology, and well construction for borehole UE-6d. .......................... 66

40. Temperature profile, lithology, and well construction for borehole ER-18-2. ………................. 68

41. Temperature profile, lithology, and well construction for borehole ER-12-2. .......................69

42. Temperature profile, lithology, and well construction for borehole ER-2-1........................ 71

43. Temperature profile, lithology, and well construction for borehole ER-6-1........................ 72

44. Temperature profile, lithology, and well construction for borehole U-15k......................... 73

45. Temperature profile, lithology, and well construction for borehole TW-D............................ 75

46. Temperature profiles, lithology, and well construction for borehole ASH-B. ...................... 76

47. Temperature profiles, lithology, and well construction for borehole LWS-A........................ 78

48. Temperature profiles, lithology, and well construction for borehole MSH-C....................... 79

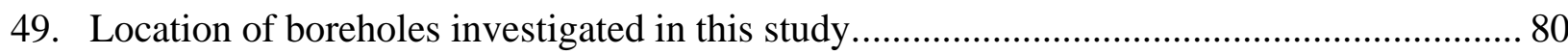

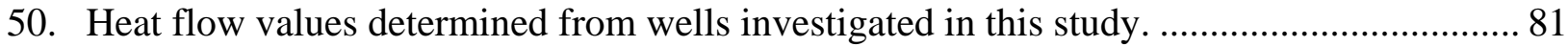

51. Heat flow values in and around Yucca Flat at the NTS........................................................ 84 


\section{LIST OF TABLES}

1. Heat flow values, from Sass and Lachenbruch (1982). .................................................. 6

2. Thermal conductivity of major volcanic rock types at the NTS, from Sass et al. (1987)... 13

3. Typical rock thermal conductivity values, from Wright and Louden (1989)..................... 13

4. Typical rock thermal conductivity values, from Johnston et al. (1981)............................ 13

5. Heat flow values $\left(\mathrm{mW} \mathrm{m}^{-2}\right)$ for boreholes investigated in this study............................... 82

\section{ACRONYMS}

ATH1 Amargosa Test Hole \#1

ATH2 Amargosa Test Hole \#2

DOE U.S. Department of Energy

DRI Desert Research Institute

LLNL Lawrence Livermore National Laboratory

NIST National Institute of Standards and Technology

NTS Nevada Test Site

UGTA Underground Test Area

USGS U.S. Geological Survey 
THIS PAGE INTENTIONALLY LEFT BLANK 


\section{INTRODUCTION}

Groundwater temperature is sensitive to the competing processes of heat flow from below and the advective transport of heat by groundwater flow. Existing geophysical temperature data were evaluated in terms of well construction, and conditions under which the data were collected, to ascertain if a particular temperature log was representative of formation temperatures. Appropriate data were then compiled and registered in three dimensions and a simple visualization of the data set was constructed.

Because groundwater temperature is sensitive to conductive and advective processes, groundwater temperature may be utilized as a tracer to further constrain the uncertainty of predictions of advective radionuclide transport models constructed for the Nevada Test Site (NTS). Since heat transport, hydrologic and geochemical models for a given area must all be consistent, devaluing the weight of those models that do not match estimated heat flow can reduce uncertainty.

The initial objective of this study (Gillespie, 2002) was to identify the quantity and quality of available heat flow data at the NTS. Although thousands of temperature logs have been conducted at the NTS, most are recorded on paper and not easily examined; therefore, during the initial portion of this investigation (Gillespie, 2002), only those temperature logs in digital format were considered. During FY 2003 and FY 2004, an additional 36 temperature profiles were obtained from boreholes at the NTS.

\section{BASIC HEAT FLOW TERMS}

Temperature, $\mathrm{T}$ (Celsius, ${ }^{\circ} \mathrm{C}$ ) provides a measurement of the free energy available at a location. This energy can be visualized as the vibration of molecules; the greater the temperature, the greater the vibration of the molecules. The vibrations of molecules with greater energy are transferred to adjacent molecules. Thus, temperature will flow through a material from locations of greater energy to areas of lower energy, a process defined as heat conduction.

Thermal gradient, $\mathrm{G}$ (degrees $\mathrm{C}$ per meter, ${ }^{\circ} \mathrm{C} \mathrm{m}^{-1}$ ), is defined as

$$
\partial \mathrm{T} / \partial \mathrm{z}=\left(\mathrm{T}_{2}-\mathrm{T}_{1}\right) / \Delta \mathrm{z}
$$

where $T_{1}$ and $T_{2}$ are temperatures measured at two points separated by distance $\Delta z$. By convention, a positive gradient is in the direction of increasing temperature. Although usually assumed to be vertical, thermal gradient is a vector quantity, and the actual direction of the maximum thermal gradient depends on the distribution of temperature in three dimensions.

The rate of one-dimensional heat flow, $\mathrm{Q}$ (milliwatts per square meter, $\mathrm{mW} \mathrm{m}^{-2}$ ) between two points, within a homogeneous thermal conductivity field, is defined as

$$
\mathrm{Q}=-\lambda * \partial \mathrm{T} / \partial \mathrm{z}
$$

where Q is conventionally taken to be positive in the direction of decreasing temperature, and $\lambda$ is a physical property of a medium known as thermal conductivity (watts per meter per degree Celsius, $\mathrm{W} \mathrm{m}^{-1_{\mathrm{o}}} \mathrm{C}^{-1}$ ), which is a measure of how easily heat is transmitted through a material. As with the thermal gradient, heat flow is a vector quantity. To determine the true vector value (magnitude and direction) of heat flow, the three-dimensional temperature distribution has to be known. 
In addition to conduction, as described above, moving fluids carry heat by advection. If the direction of heat flow from conduction and advection coincide, the effect can be quantified by considering the ratio of fluid-transported heat to conducted heat. This ratio is called the Peclet number $(\mathrm{Pe})$. Conduction appears to be the dominant means by which heat is transported through the Earth's crust. A compilation of conductive heat flow measured over much of the Earth's surface suggests a global mean heat flow of approximately $87 \mathrm{~mW} \mathrm{~m}^{-2}$ (Pollack et al., 1993).

\section{Thermal Gradient}

Measurement of a thermal gradient, at a minimum, requires the determination of temperatures measured at two points separated by a known distance. However, the better defined the temperature distribution, the greater the accuracy to which a thermal gradient and, therefore, heat flow can be determined.

Temperature measurements in fluid-filled boreholes are obtained by direct measurement using high-precision downhole temperature logging tools. Modern downhole temperature logging tools have resolutions of approximately $0.001^{\circ} \mathrm{C}$; however, accuracy is rarely better than $\pm 2^{\circ} \mathrm{C}$ for any given logging tool. Conducting a two-point calibration before conducting the temperature log, as well as an additional two-point calibration check following logging, can enhance the accuracy of the temperature measurement. In general, a two-point calibration consists of recording the temperature tool response at two known temperatures and using this information to correct the temperatures measured by the tool during logging. Using the two-point calibration method, accuracy of a temperature tool can usually be increased to within $\pm 0.1^{\circ} \mathrm{C}$. Although accuracy is desirable, it should be noted that since we are using thermal gradients to determine heat flow, absolute accuracy of the temperature measurements is not critical.

Temperatures measured in the boreholes must be representative of actual formation temperatures outside the borehole to be useful in the determination of heat flow. Ideally, the borehole should be cased to prevent cross flow between aquifers penetrated by the borehole. Additionally, the annular space between the casing and the borehole should be cemented, or otherwise sealed, through the saturated portion of the borehole to prevent cross flow between aquifers in the annular space. Although the casing in most boreholes is only "tack" cemented within a borehole for a few tens or hundreds of meters above the base of the casing, collapse of the less competent formations penetrated by the wellbore into the annular space will often effectively seal the annular space. Furthermore, sufficient time must be allowed, following construction of the borehole, for fluid within the borehole to return to thermal equilibrium with the surrounding formations.

Another factor that must be considered is convection of fluid within a borehole. Convection is the movement of water, and subsequently heat, due to temperature-induced difference in fluid density. Since, generally, borehole temperatures increase with depth, it would appear that the warmer waters deeper within the borehole would tend to rise up through the cooler fluids higher in the borehole, producing convection cells. Hales (1937), Auld (1948), and Diment (1967) investigated this phenomenon and developed, and refined, an equation to describe convection in boreholes relating fluid properties and the radius of the borehole to a critical thermal gradient, above which convection would be expected. Using this equation, it can be shown that for normal geothermal gradients (approximately $25^{\circ} \mathrm{C} / \mathrm{km}$ ), convection can be expected in boreholes with diameters greater than about $5 \mathrm{~cm}$. However, several field investigations by Urban et al. (1978), Diment (1967), Gretener (1967), and Wisian et al. (1998), 
as well as the observations by this author, have shown that although convection cells do form, they rarely extend vertically more than a few borehole diameters before dying out. Thus, the general effect of convection within boreholes is to decrease the signal-to-noise ratio of a temperature log without interfering with broader temperature trends. For example, it would be impossible to discern minute changes in gradient produced by lithologic units with thickness smaller than a few borehole diameters, however, the overall gradient of a unit several meters thick, in a borehole of several tens of centimeters in diameter, could be accurately determined. Essentially, boreholes with higher thermal gradients and larger diameters produce noisier temperature logs.

\section{Thermal Conductivity}

Thermal conductivity is a measure of how easily heat is transmitted through a material and is an inherent physical property of that material. It must be noted that the thermal conductivity of a material may be anisotropic, that is, having different values for different directions through the same material.

Thermal conductivity and lithology are closely related. To determine heat flow values from a thermal gradient profile, it is essential that the thermal conductivity of the lithologies penetrated by the boreholes be determined as accurately as possible.

The thermal conductivity of a rock is a function of the composition and geometry of its constituent minerals and pore fluids. If the type, percentage volume, and thermal conductivity values of a rock's mineral constituents and pore fluids are known, the thermal conductivity of the rock may be estimated by calculating a mean of the thermal conductivity of the rock's component parts (De Vries, 1963). However, this method does not account for the geometric orientation of the mineral constituents of the rock.

Ideally, each lithology in a study area should be sampled multiple times and their range of physical thermal conductivity determined in the laboratory. Once the range of thermal conductivity of the various lithologic units has been determined, it may be possible to relate various geophysical logs (primarily those that measure mineralogy and porosity) to thermal conductivity.

\section{Heat Flow}

One-dimensional heat flow, in a homogeneous thermal conductivity field, is the product of two values: thermal conductivity multiplied by the thermal gradient. This applies whether the thermal gradient is measured over an interval of uniform thermal conductivity, or an average thermal gradient is measured over an interval of averaged thermal conductivity values. For purely conductive vertical heat flow under steady upper and lower boundary conditions, heat flow values will remain constant (Figure 1). Figure 1 also illustrates that for a thicknessweighted, harmonic mean, thermal conductivity for all intervals

$$
\lambda_{\text {avg }}=\Delta \mathrm{z} /\left[\Delta \mathrm{z}_{1} / \lambda_{1}+\Delta \mathrm{z}_{2} / \lambda_{2}+\Delta \mathrm{z}_{3} / \lambda_{3} \ldots\right]=2.66 \mathrm{~W} \mathrm{~m}^{-1}{ }^{\circ} \mathrm{C}^{-1}
$$

combined with a thermal gradient of

$$
\mathrm{G}=\Delta \mathrm{T} / \Delta \mathrm{z}=0.023^{\circ} \mathrm{C} \mathrm{m}^{-1}
$$

results in a heat flow of $0.06 \mathrm{~mW} \mathrm{~m}^{-2}$. 
Variations in vertical heat flow can result from many sources. Obviously, errors in temperature measurement and/or thermal conductivity values will result in erroneous estimates of heat flow values. Additionally, several thermal conditions may produce variations in vertical heat flow. Radiogenic heat (heat produced by radioactive decay within the rocks themselves) will produce additional heat energy within the rock unit. This results in a gradual increase in the measured heat flow within the unit and greater heat flow values in adjacent rock units above relative to units below the heat-producing interval.

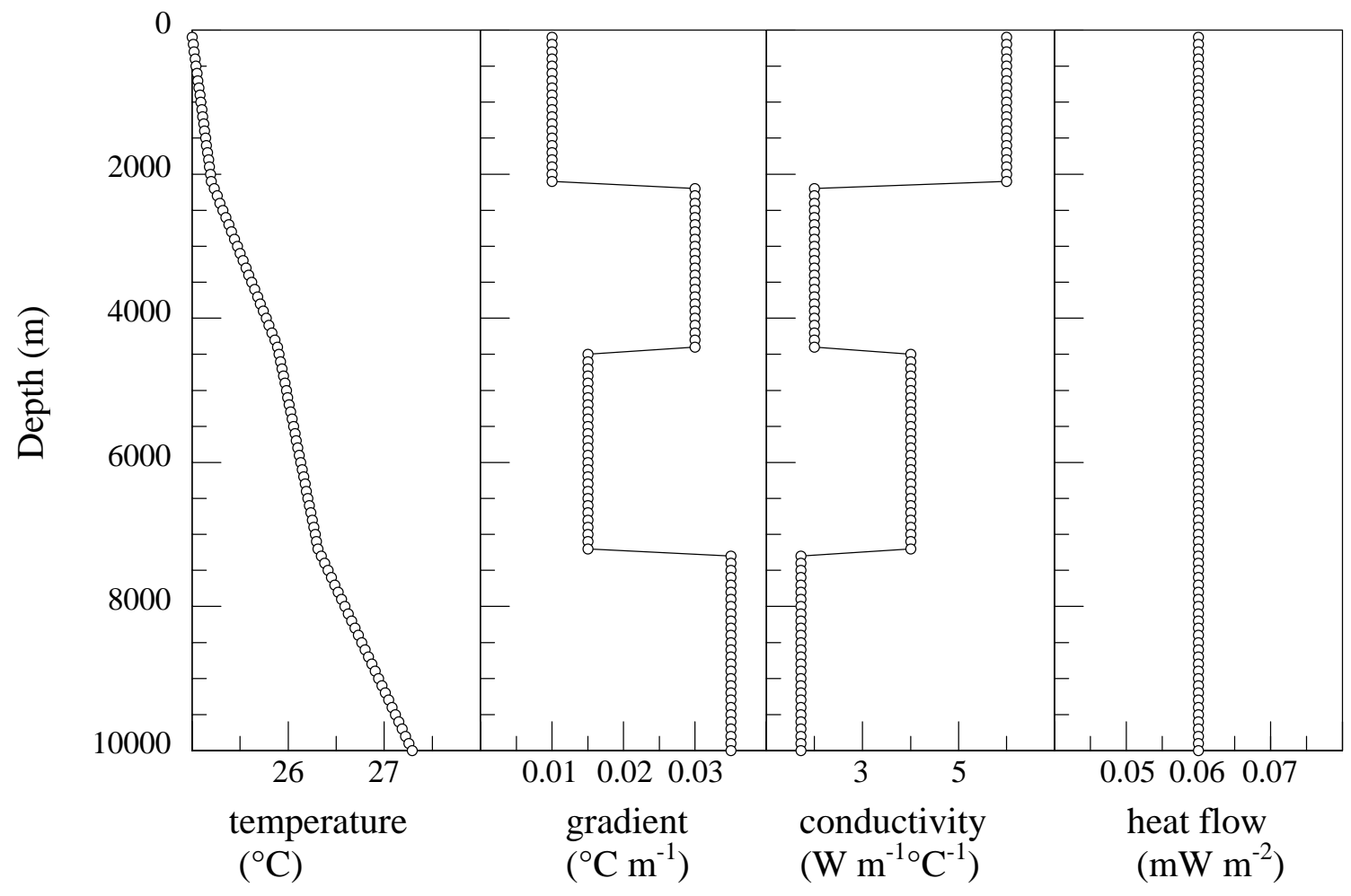

Figure 1. Relationship between temperature, thermal gradient, thermal conductivity, and heat flow in a purely conductive thermal regime.

Climate change, sedimentation, and erosion produce variations in vertical heat flow profiles by changing the upper boundary condition. Basement relief and topography produce nonhorizontal surface boundaries that distort heat flow away from the vertical. Like most other forms of energy, heat generally will follow the path of least resistance. Heat will be refracted around areas of thick or low-conductivity rocks and be channeled to areas with elevated basement rock. In mountainous areas, heat preferentially flows into valleys and surface heat flow will vary with elevation.

Calculating heat flow from observed temperature gradients, assuming one-dimensional conductive heat flow in a homogeneous thermal conductivity field, can result in erroneous heat flow estimates in an advectively disturbed thermal regime. Groundwater movement can disturb the temperature field, causing it to differ from the purely conductive case. The advective transport of heat by the vertical movement of groundwater will cause the calculated conductive 
heat flux to decrease or increase with elevation depending on the direction of flow. Calculated conductive heat flux will decrease with elevation in the borehole when groundwater movement is downward and vice versa. As groundwater moves horizontally through a porous rock unit, the fluid repeatedly is divided and recombined. This dispersion, or mixing, of the groundwater has the effect of lowering the thermal gradient within the rock unit without affecting the actual vertical heat flow, thus resulting in an apparent increase in the thermal conductivity of the unit. Therefore, when the actual thermal conductivity of an aquifer with horizontal flow is used to calculate heat flow, the zone would appear as an interval of low heat flow compared to those units above and below the aquifer.

\section{PREVIOUS INVESTIGATIONS}

The earliest heat flow and thermal studies (e.g., Van Orstrand, 1934; Bullard, 1939; Birch, 1947) found that purely conductive heat flow could not explain the subsurface temperature distributions observed in their investigations. Subsequent heat flow investigations (i.e., Lachenbruch et al., 1976; Reiter et al., 1979; Chapman et al., 1981) confirmed these findings and established the role of advective heat transport by groundwater in controlling subsurface thermal regimes. Smith and Chapman (1983) and Woodbury and Smith (1985) presented numerical solutions of the equations of fluid flow and heat transport to quantify the effects of groundwater flow on the subsurface thermal regime and showed that with sufficient knowledge of the complete environment of a site, including water table elevations and boundary conditions, and with adequate spacing between measurement points, advectively perturbed thermal fields could be used to infer hydraulic parameters.

In addition to investigations of the effect of advective heat transport by groundwater, recent heat flow studies have been undertaken to determine the thermal history of sedimentary basins to understand petroleum migration and maturation (Lopatin et al., 1976; Hunt et al., 1991; Lowrie et al., 1996;). Investigations of the subsurface thermal regime have also recently been utilized to estimate historical climate changes as evidence of global warming (Beck, 1992; Chisholm and Chapman, 1992; Pollack, 1993; Whiteford, 1993; Beltrami and Taylor, 1995; Deming and Borel, 1995; Huang et al., 2000).

Previous heat flow investigations at the NTS (e.g., Sass et al., 1980, 1987; Fridrich et al., 1994) have been conducted primarily in conjunction with hydrologic studies at the proposed Yucca Mountain High-level Nuclear Waste Repository site.

Pottorff et al. (1987) examined temperature profiles from numerous emplacement boreholes in Areas 19 and 20 at the NTS in an attempt to obtain quantitative information on the hydrologic regime of Pahute Mesa. A qualitative assessment of the logs provided useful information on static water levels and areas of water influx into the boreholes, however, Pottorff determined that the uncertain quality of the data and the effects (convection) of the large diameter of the boreholes (25 to $183 \mathrm{~cm}$ ) rendered the data of little value for quantitative hydrologic analysis.

Sass and Lachenbruch (1982) examined temperature data from 60 boreholes in and around the NTS, including 16 from the Yucca Mountain area. They determined that, based on the shape of the temperature profiles, 15 of the 60 temperature logs were usable for the determination of heat flow values (Table 1). The original digital temperature data used by Sass and Lachenbruch (1982) were obtained by the U.S. Geological Survey (USGS) and were not available for review and interpretation by this author. Additionally, Sass and Lachenbruch (1982) 
utilized temperature data from portions of boreholes without casing in place. These borehole temperature profiles may have been influenced by vertical fluid flow within the borehole and therefore the measured gradient may not represent the actual thermal regime outside the borehole. In this study, only those portions of boreholes with casing, where vertical fluid flow within the borehole is impossible, or at least extremely unlikely, were used to determine geothermal gradients.

Table 1. Heat flow values from Sass and Lachenbruch (1982).

\begin{tabular}{cc}
\hline Well Name & Heat Flow $\left(\mathrm{mW} \mathrm{m}^{-2}\right)$ \\
\hline PM-2 & 63 \\
PM-1 & 42 \\
DOL & 80 \\
U15K & 56 \\
UE-17e & 66 \\
TW-E & 29 \\
J-13 & 67 \\
UE-25a1 & 54 \\
UE-25b1 & 47 \\
UE-25a3 & 130 \\
USWG1 & 52 \\
TW-F & 76 \\
TW-3 & 92 \\
TW-5 & 84 \\
TW-4 & 91 \\
\hline
\end{tabular}

\section{EVALUATION OF EXISTING NTS TEMPERATURE LOGS}

In the initial phase of this investigation, 145 temperature logs from 63 wells (Figure 2) on or near the NTS were examined. Of these 145 temperature logs, 62 were obtained from Bechtel Nevada and were run by Atlas Wireline Services. Seventeen of the temperature logs were obtained from Lawrence Livermore National Laboratory (LLNL) and were run by LLNL. The Desert Research Institute (DRI) ran the remaining 66 temperature logs.

Because it is necessary for a borehole, following construction, to return to thermal equilibrium with the surrounding rock, the 145 temperature logs were ranked based on the length of time that had passed since completion of the borehole. The time required for a borehole to return to thermal equilibrium with the surrounding formations depends on several factors: the length of time taken to drill the borehole, the diameter of the borehole, the temperature and amount of fluids introduced to and/or removed from the borehole during construction, lithology (porosity/thermal conductivity) of the formations penetrated by the borehole, the amount and temperature of drilling fluid lost to the formations during drilling, etc. In general, at the completion of the drilling process, the upper two-thirds of the borehole have been warmed relative to the actual temperature of the surrounding formations and the lower one-third of the borehole has been cooled relative to the actual temperature of the surrounding formations. Given the wide variability of these factors, thermal equilibrium of a borehole may require days, months, years, or even decades. The only method to ensure a borehole has returned to thermal equilibrium is to obtain two temperature logs sufficiently separate in time to verify thermal stability of the borehole. As will be shown later in this report, of the previously existing 
temperature profiles selected for analysis only one borehole was logged twice with a sufficiently long intervening period of time to ensure thermal equilibrium. Therefore, a time of one year between completion of the borehole and conduction of the temperature log was somewhat arbitrarily selected as the minimum time necessary for a borehole to return to thermal equilibrium. This resulted in 88 temperature logs that were obtained less than one year after borehole completion; seven temperature logs were obtained between one and two years since their boreholes were completed; and 41 of the temperature logs were conducted more than two years after their boreholes were completed. Two of the temperature logs had no logging dates. The remaining seven temperature logs were obtained in emplacement holes with borehole diameters large enough, and/or with logged intervals short enough, to have rendered the data questionable due to the possible presence of convection cells. The 48 usable temperature logs were acquired from 39 boreholes.

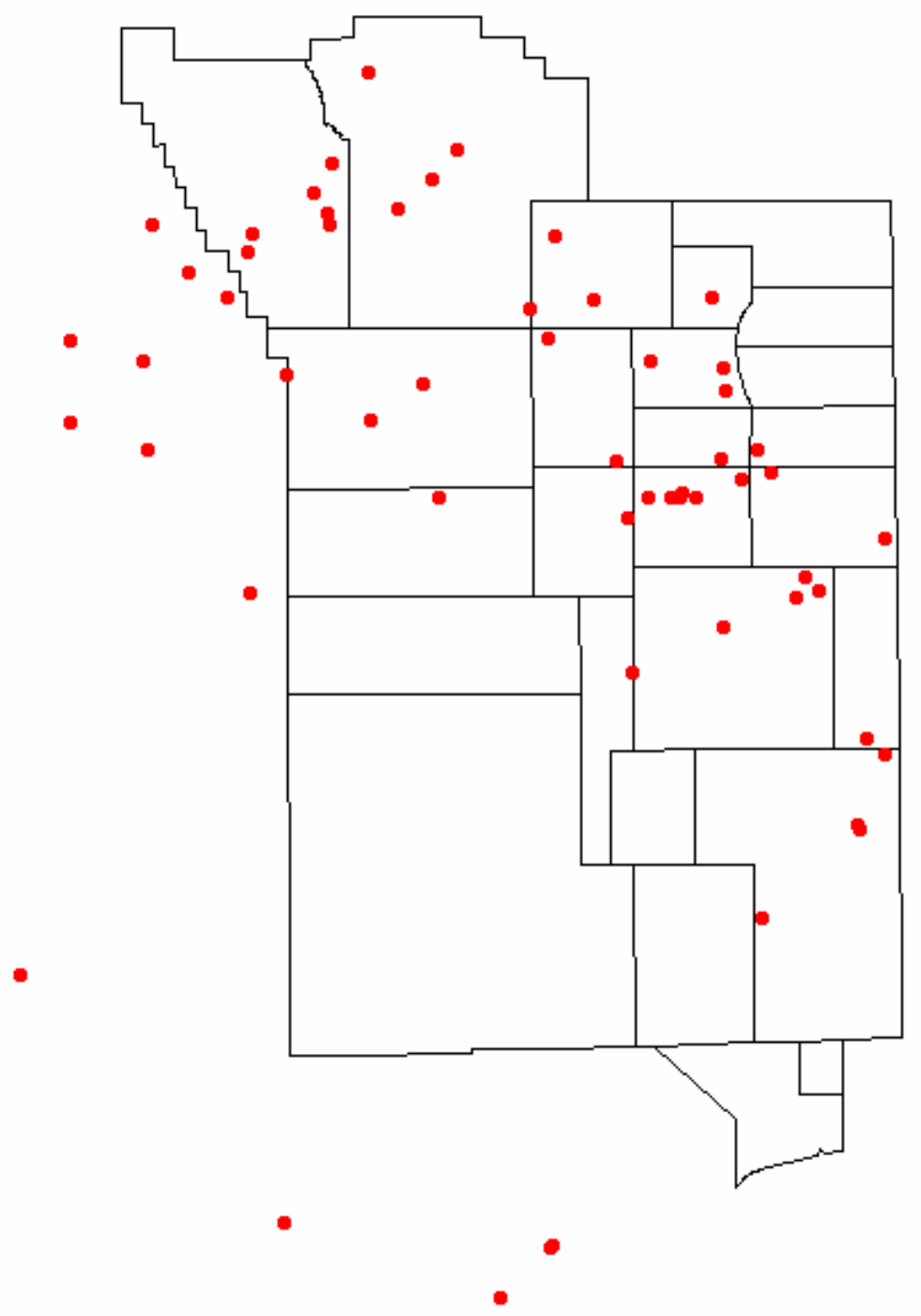

Figure 2. Location of boreholes at the NTS with previously existing temperature logs examined in this investigation. 
Construction information (depth of casing, presence of slotted casing or perforations, etc.) for the 39 boreholes logged one year or more after the completion of drilling was assembled and evaluated to eliminate those boreholes where vertical flow within the borehole might be present. Also eliminated were those boreholes with temperature profiles collected from too short of an interval relative to the borehole diameter to yield accurate heat flow values. Additionally, one borehole, ER-6-1\#1, was determined to be located approximately $15 \mathrm{~m}$ from borehole ER-6-1 in which drilling activity was conducted six months prior to temperature logging at ER-6-1\#1. Residual thermal impacts from the drilling of ER-6-1 may have impacted the temperature profile of well ER-6-1\#1. For this reason, the temperature profile from well ER-6-1\#1 was eliminated from further analysis. A total of 13 boreholes (Figure 3) were determined to have existing temperature profiles suitable for the determination of heat flow values.

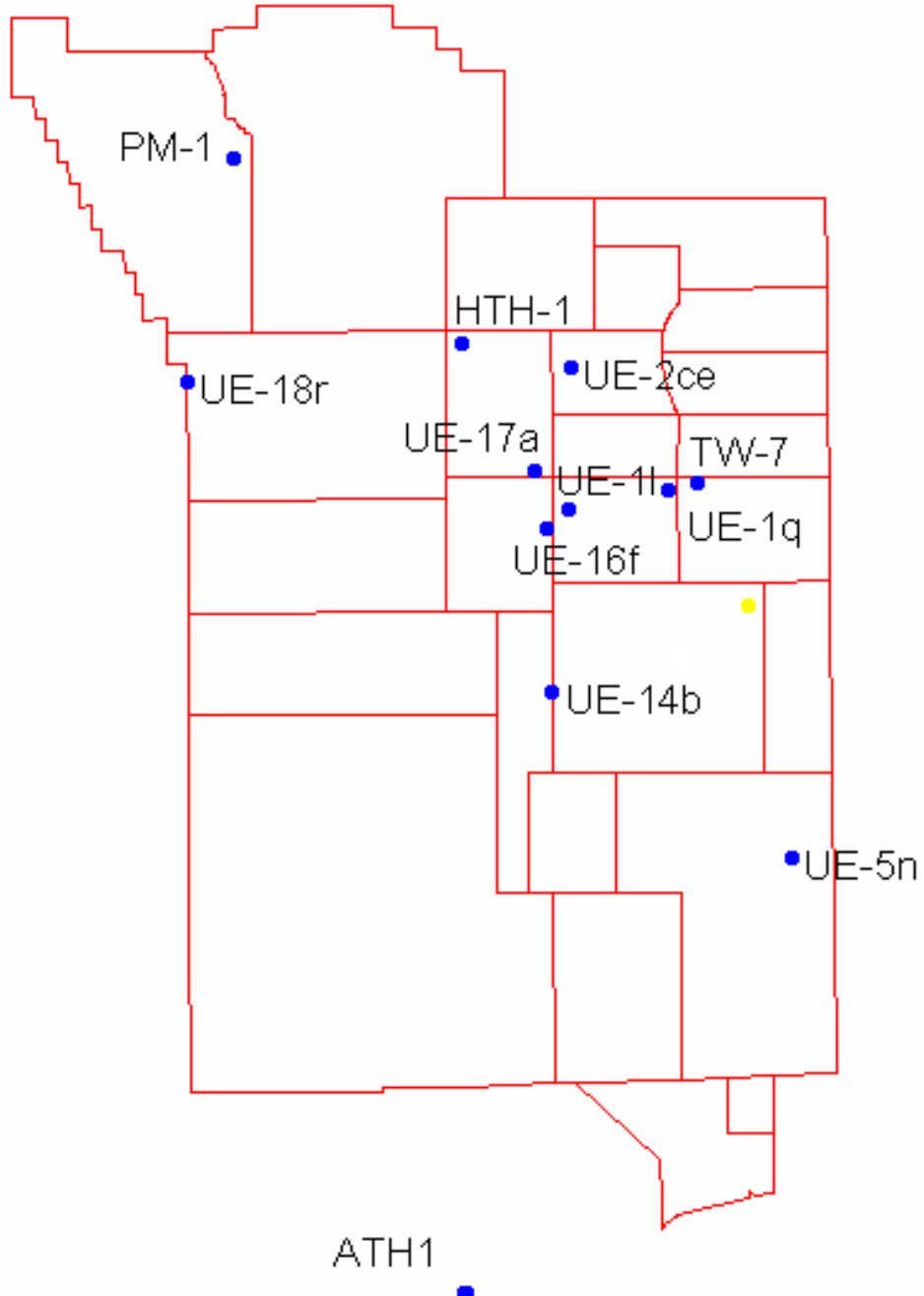

$\mathrm{ATH} 2$

Figure 3. Boreholes on, or near, the NTS determined to have existing temperature profiles suitable for the determination of heat flow values 


\section{COLLECTION OF NEW TEMPERATURE DATA FROM NTS BOREHOLES}

Following evaluation and analysis of the 13 existing temperature profiles from the NTS, an additional 21 boreholes (Figure 4) were selected for temperature logging during FY 2003. Five of these 21 boreholes were selected for comparison with previously obtained temperature profiles. The remaining 16 boreholes were selected based on construction, and for which it appeared a sufficient duration of time had passed from when the borehole was completed to permit the borehole to return to thermal equilibration with the surrounding formations. Additionally, a previously measured temperature profile (borehole UE-18t) that was overlooked in the initial investigation of existing temperature profiles from the NTS was discovered, and borehole PM-1 was re-logged during an operational check of a new wireline for DRI's geophysical logging unit. Also included are three temperature profiles from the Underground Test Area (UGTA) borehole ER-5-4\#2, which are examined to evaluate the thermal recovery of a newly constructed borehole. Temperature data, borehole construction, and lithologic information utilized in this report are presented in a Microsoft Access Database included in the Appendix.

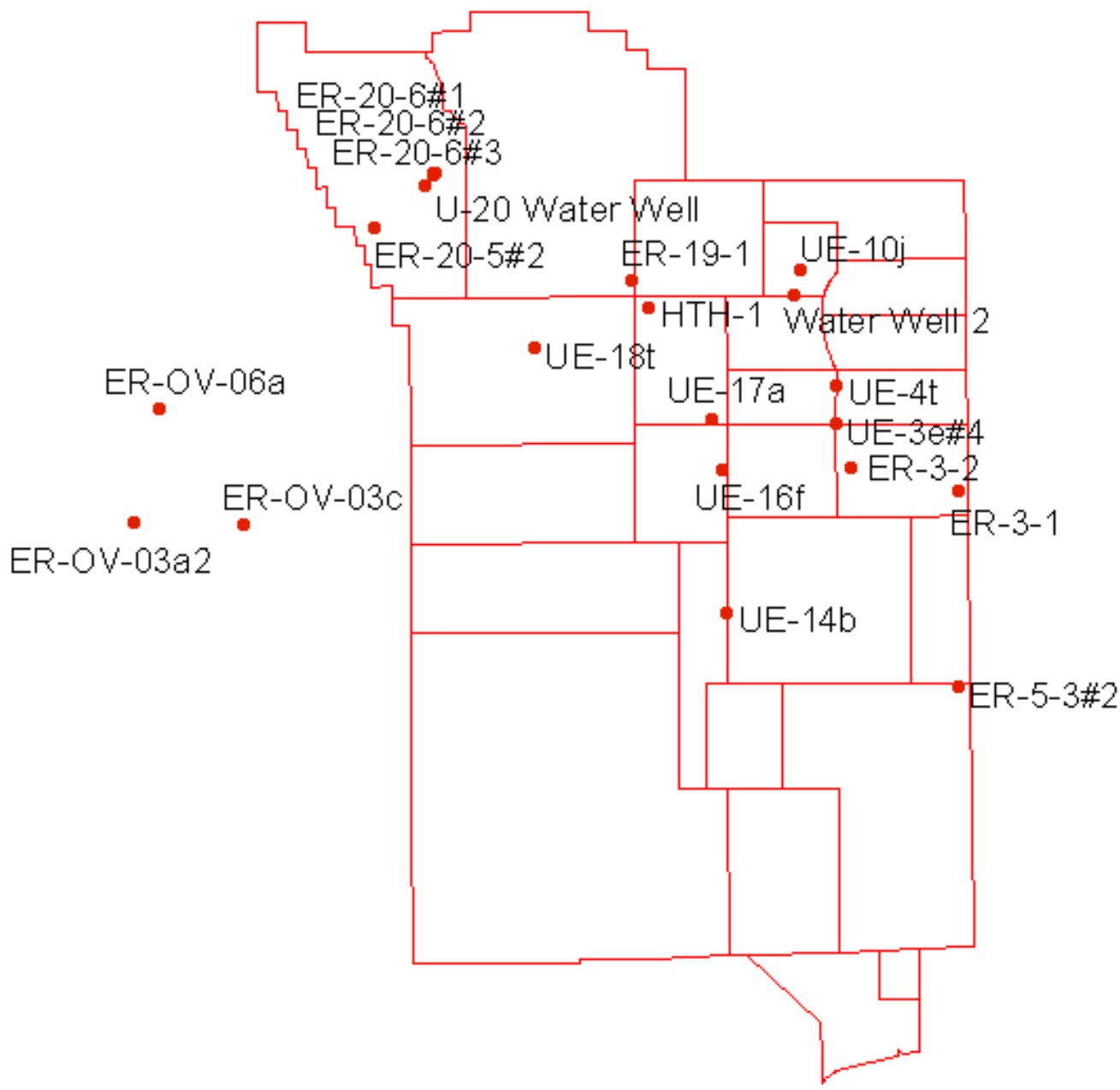

Figure 4. Location of boreholes on, or near, the NTS that were temperature logged during FY 2003 as part of this investigation. 
During FY 2004, an additional 15 temperature profiles were obtained from boreholes on and near the NTS (Figure 5). Ten of these boreholes were logged for the first time following construction or recompletion of the borehole. The other five boreholes were selected for comparison with previously obtained temperature profiles.

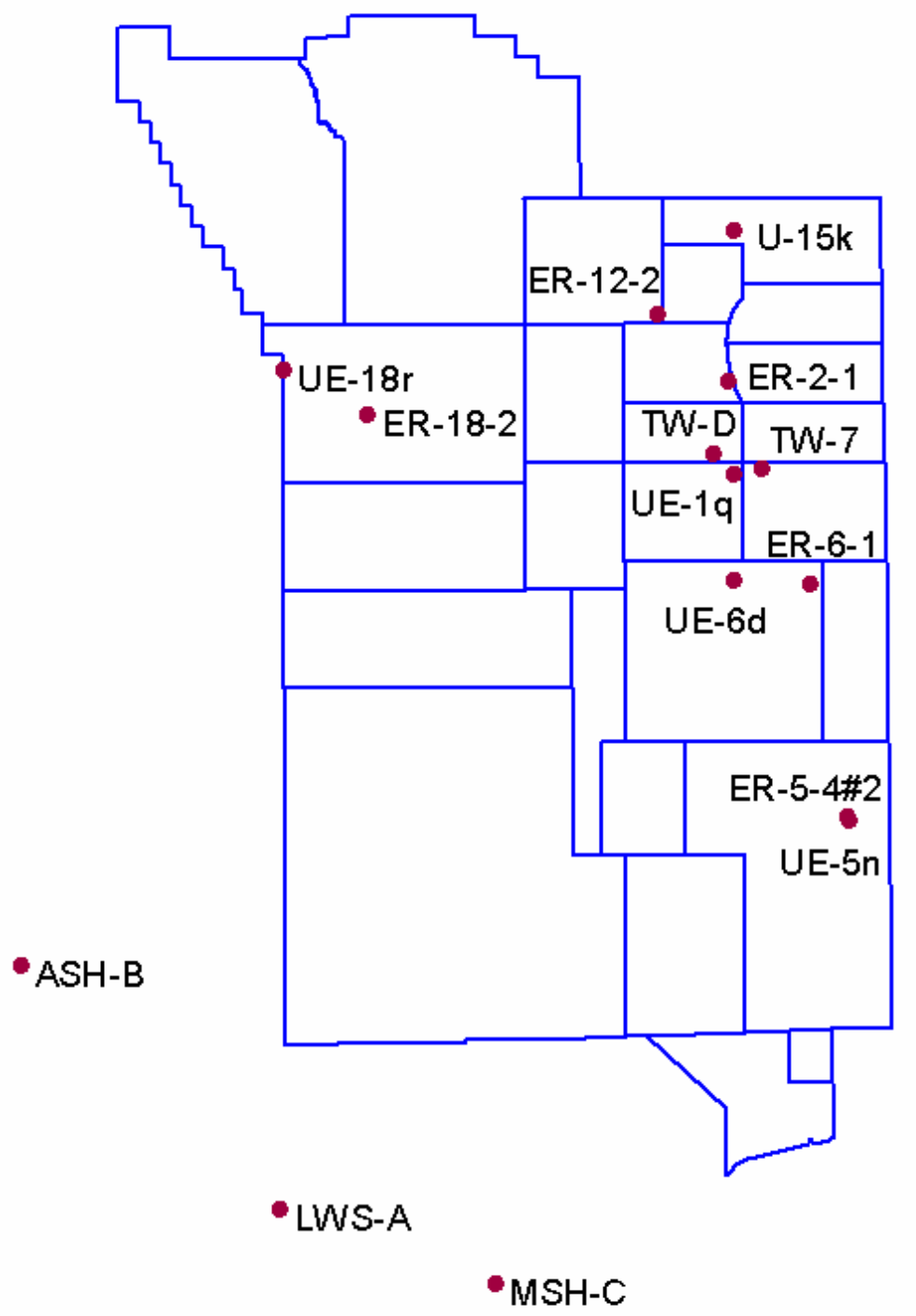

Figure 5. Location of boreholes on, or near, the NTS that were temperature logged during FY 2004 as part of this investigation.

Limited information was available concerning the calibration and accuracy of the 13 previously existing temperature profiles examined in this investigation. Older temperature profiles conducted by DRI using a thermistor within a stainless-steel housing (manufactured by DRI personnel), DRI's Chemtool (also manufactured by DRI personnel), or DRI's 20-pulse 
temperature tool were calibrated before and after logging using a two-point field temperature calibration. All temperature profiles obtained by DRI for this investigation using DRI's PHASe logging tool were calibrated using a two-point temperature calibration. The calibration of the DRI PHASe temperature probe has been frequently conducted in the field (usually at the beginning and end of logging, or at the beginning and end of a day's logging activity). The results of these calibration checks are shown in Figure 6. The correlation coefficient $\left(\mathrm{R}^{2}\right)$ of 0.999, with a slope of 0.969 and offset of $2.22{ }^{\circ} \mathrm{C}$, indicates an excellent correlation between the National Institute of Standards and Technology (NIST) standard digital thermometer and the PHASe temperature probe. Utilizing the results of these calibration checks, all temperature data collected from boreholes using the PHASe temperature probe were corrected prior to analysis and inclusion in this study.

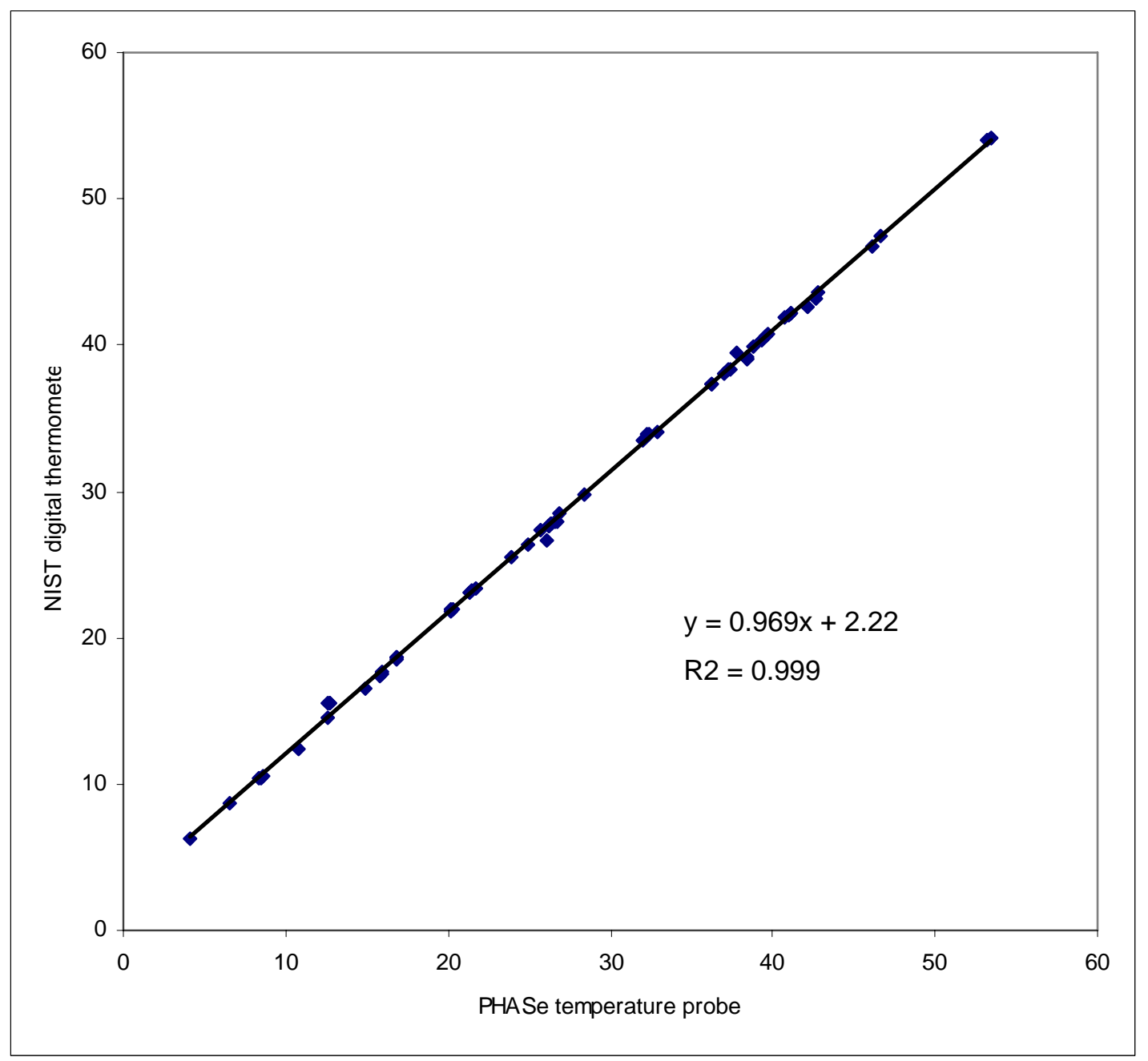

Figure 6. Field calibration results for DRI's PHASe temperature probe using the NIST digital thermometer. 


\section{THERMAL CONDUCTIVITY VALUES FOR NTS LITHOLOGIES}

To determine heat flow values from temperature profiles, the thermal conductivity of the lithologies penetrated by the borehole must be known. Sass et al. (1987) measured thermal conductivities of 135 specimens of volcanic tuffs and 13 specimens of Paleozoic carbonates obtained from core samples retrieved from saturated portions of boreholes drilled at the Yucca Mountain Site (Figure 7 and Table 2).

Average thermal conductivity for all of the volcanic tuff lithologies measured by Sass et al. (1987) was $1.72 \pm 0.3 \mathrm{~W} \mathrm{~m}^{-1}{ }^{\circ} \mathrm{C}^{-1}$. For the 13 specimens of Paleozoic carbonate lithology, an average thermal conductivity of $5.0 \mathrm{~W} \mathrm{~m}^{-1}{ }^{\circ} \mathrm{C}^{-1}$ was determined. It should be noted that given the relatively small number of samples of each lithology, together with the marked similarity of the mean values and standard deviation between 0.1 and 0.5 , many of the mean values are not statistically different. For example, the mean value for the welded tuff and moderately welded tuff are not statistically different. However, a definite trend in increasing thermal conductivity with increased density of welding is readily observable.

Johnston et al. (1981) and Wright and Louden (1989), as well as others, have published thermal conductivity values for various rock types (Tables 3 and 4).

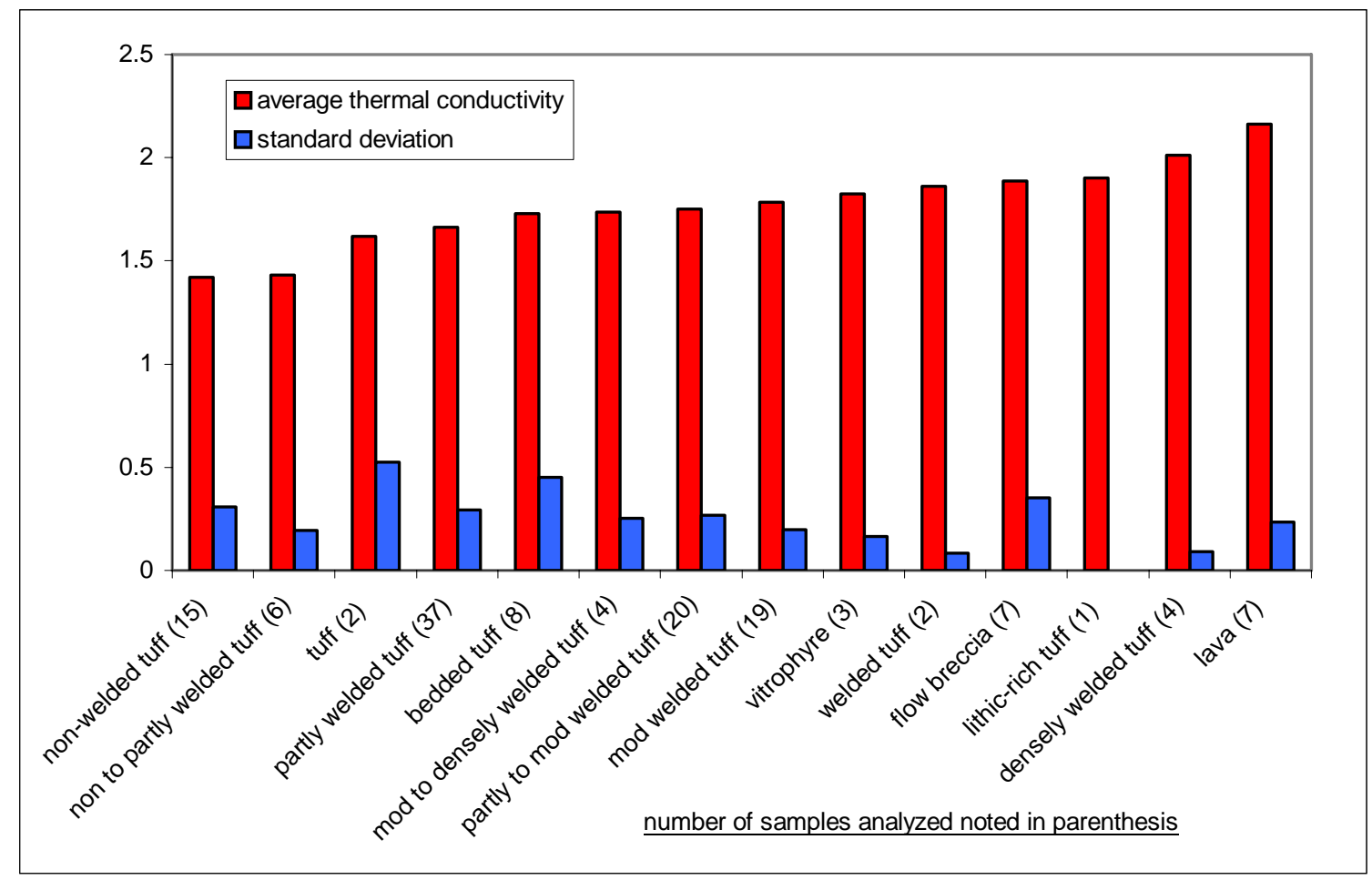

Figure 7. Laboratory measured thermal conductivity values $\left(\mathrm{W} \mathrm{m}^{-1}{ }^{\circ} \mathrm{C}^{-1}\right.$ ) for Tertiary volcanic lithologies (Sass et al., 1987). 
Table 2. Thermal conductivity of major volcanic rock types at the NTS, from Sass et al. (1987).

\begin{tabular}{cccccc}
\hline Lithology Type & $\begin{array}{c}\text { Thermal } \\
\text { Conductivity } \\
\text { minimum }\end{array}$ & $\begin{array}{c}\text { Thermal } \\
\text { Conductivity } \\
\text { average }\end{array}$ & $\begin{array}{c}\text { Thermal } \\
\text { Conductivity } \\
\text { maximum }\end{array}$ & $\begin{array}{c}\text { Number of } \\
\text { Samples }\end{array}$ & $\begin{array}{c}\text { Standard } \\
\text { Deviation }\end{array}$ \\
\hline nonwelded tuff & 1.06 & 1.42 & 2.1 & 15 & 0.3092 \\
non to partly welded tuff & 1.23 & 1.43 & 1.73 & 6 & 0.1936 \\
tuff & 1.25 & 1.62 & 1.99 & 2 & 0.5232 \\
partly welded tuff & 1.19 & 1.66 & 2.31 & 37 & 0.2931 \\
bedded tuff & 1.1 & 1.73 & 2.42 & 8 & 0.4515 \\
moderately to densely welded tuff & 1.36 & 1.73 & 1.9 & 4 & 0.2537 \\
partly to moderately welded tuff & 1.37 & 1.75 & 2.26 & 20 & 0.2681 \\
moderately welded tuff & 1.37 & 1.78 & 2.21 & 19 & 0.1967 \\
vitrophyre & 1.67 & 1.82 & 2 & 3 & 0.1662 \\
welded tuff & 1.8 & 1.86 & 1.92 & 2 & 0.0848 \\
flow breccia & 1.43 & 1.89 & 2.46 & 7 & 0.3536 \\
lithic-rich tuff & 1.9 & 1.9 & 1.9 & 1 & NAN \\
densely welded tuff & 1.94 & 2.01 & 2.15 & 4 & 0.0936 \\
lava & 1.77 & 2.16 & 2.49 & 7 & 0.2360 \\
dolomite & 4.45 & 4.95 & 5.47 & 13 & 0.2848 \\
\hline
\end{tabular}

Table 3. Typical rock thermal conductivity values from Wright and Louden (1989).

\begin{tabular}{cc}
\hline Rock Types & Thermal Conductivity $\left(\mathrm{W} \mathrm{m}^{-1}{ }^{\circ} \mathrm{C}^{-1}\right)$ \\
\hline All mudstones & 1.85 \\
Calcium mudstones & 1.76 \\
Silty mudstones & 2.15 \\
Siltstone & 1.91 \\
Muddy sandstones & 2.23 \\
All sandstones & 2.92 \\
Quartz sandstone & 5.09 \\
All limestones & 2.51 \\
Dolomite & 4.78 \\
\hline
\end{tabular}

Table 4. Typical rock thermal conductivity values from Johnston et al. (1981).

\begin{tabular}{cc}
\hline Rock Types & Thermal Conductivity $\left(\mathrm{W} \mathrm{m}^{-1}{ }^{\circ} \mathrm{C}^{-1}\right)$ \\
\hline Shale & 1.5 \\
Evaporites & 5.4 \\
Limestone & 1.3 to 5.0 \\
Dolomite & 5 \\
Sandstone & 1.8 to 4.2 \\
Schist & 1.6 \\
Gneiss & 2.5 \\
Greenstone & 3.3 \\
Slate & 3.8 \\
Argillite & 3.3 \\
Quartzite & 4.5 to 7.1 \\
Granite & 1.7 to 4.0 \\
Diabase & 2.1 \\
Gabbro & 2.5 \\
Granodiorite & 2.6 \\
\hline
\end{tabular}


Utilizing published thermal conductivity values (Tables 2, 3, and 4) and measured geothermal gradients, heat flow values were determined for existing temperature profiles and temperature profiles obtained by DRI for this investigation. The following section contains a discussion of individual borehole construction, associated temperature profiles, and resultant calculated heat flow values. For those boreholes with more than one temperature profile, an evaluation of the accuracy of the previous temperature profile and resultant heat flow values, relative to results obtained with DRI's PHASe temperature probe, is presented. For clarity, the initial few meters of most temperature profiles have been deleted from the data presented because when a temperature probe first enters the fluid within a borehole there is generally a large change in temperature as the probe equilibrates with the temperature of the fluid.

\section{DISCUSSION OF WELL CONSTRUCTION, TEMPERATURE PROFILES, AND CALCULATED HEAT FLOW VALUES}

\section{UE-1q}

UE-1q was first completed in May 1980. The borehole was subsequently recompleted by deepening, to a total depth of $792.48 \mathrm{~m}$ below ground surface and a 27.3-cm-diameter casing emplaced to a depth of $749.5 \mathrm{~m}$ in May 1992. The annular space between this casing and the borehole was cemented to the surface. The initial temperature profile for this borehole was conducted by DRI on July 19, 1994, using DRI's Chemtool. The second profile was obtained by DRI on April 22, 2004, using DRI's PHASe temperature logging tool. A cross plot of two temperature profiles yields a correlation coefficient $\left(\mathrm{R}^{2}\right)$ of 0.9998 , with a slope of 0.9613 .

As shown in Figure 8, the contact between the Tertiary tuff units and the Paleozoic carbonate aquifer occurs at a depth of $710.8 \mathrm{~m}$ below ground surface. The casing was cemented within the borehole to a depth of $749.5 \mathrm{~m}$ below ground surface. Depth to static water level in UE-1q is $504.5 \mathrm{~m}$, resulting in approximately $245 \mathrm{~m}$ of fluid above the bottom of the casing within the borehole.

The temperature profiles from borehole UE-1q display a pronounced break in the geothermal gradient coincident with the volcanic tuff/carbonate contact at a depth of $710 \mathrm{~m}$ below ground surface. A least-squares fit through the portion of the temperature profile measured in the Tertiary tuff lithologies penetrated by UE-1q yields a geothermal gradient of $0.0195^{\circ} \mathrm{C} \mathrm{m}^{-1}$ using the Chemtool temperature profile and a gradient of $0.02{ }^{\circ} \mathrm{C} \mathrm{m}^{-1}$ using the profile obtained with the PHASe tool. A least-squares fit through the portion of the temperature profile measured in the carbonate lithology above the base of the casing within UE-1q yields a geothermal gradient of $0.0057^{\circ} \mathrm{C} \mathrm{m}^{-1}$, using the Chemtool temperature profile, and a gradient of $0.0066^{\circ} \mathrm{C} \mathrm{m}^{-1}$, using the profile obtained with the PHASe tool. The tuff units penetrated by UE-1q are comprised primarily

of nonwelded and bedded tuff units. If a thermal conductivity of $1.54 \mathrm{~W} \mathrm{~m}^{-1}{ }^{\circ} \mathrm{C}^{-1}$ is assigned for the Tertiary units and $5.0 \mathrm{~W} \mathrm{~m}^{-1}{ }^{\circ} \mathrm{C}^{-1}$ for the carbonate lithology (Sass et al., 1987), heat flow values for either lithology using either temperature profile would be approximately $30 \mathrm{~mW} \mathrm{~m}^{-2}$ (28 to $33 \mathrm{~mW} \mathrm{~m}^{-2}$ ).

\section{UE-18r}

UE-18r (Figure 9) was completed in August 1968 to a depth of 1,525.2 m below ground surface. Casing, $27.3 \mathrm{~cm}$ in diameter, was cemented in the borehole to a depth of $496.5 \mathrm{~m}$ below ground surface. Depth to static water level in the well is $416 \mathrm{~m}$ below ground surface, resulting in approximately $80 \mathrm{~m}$ of fluid above the bottom of the casing in the borehole. The saturated 
portion of the borehole above the bottom of the casing is located entirely within a unit of nonwelded tuff.
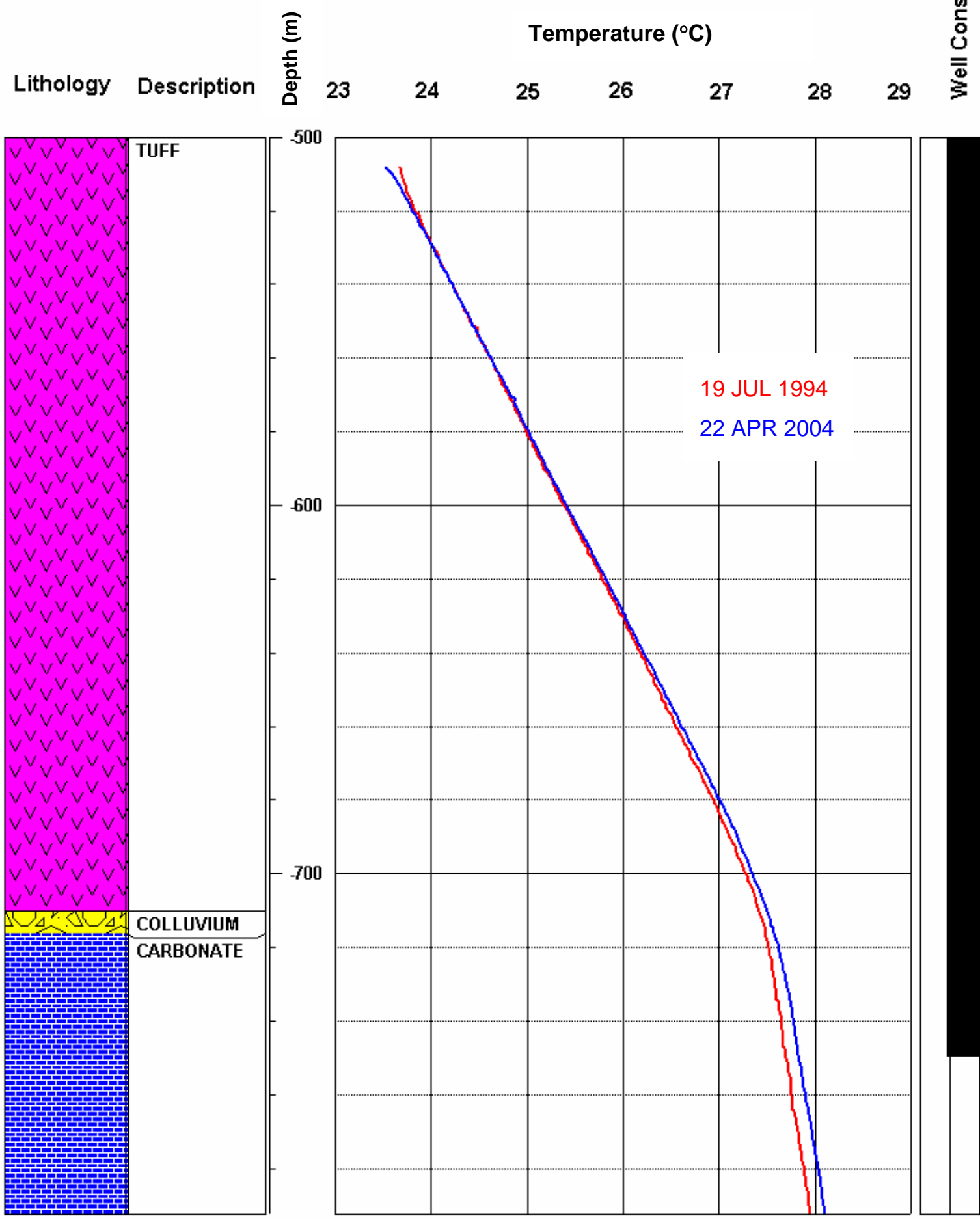

Figure 8. Temperature profiles, lithology, and well construction for borehole UE-1q. 


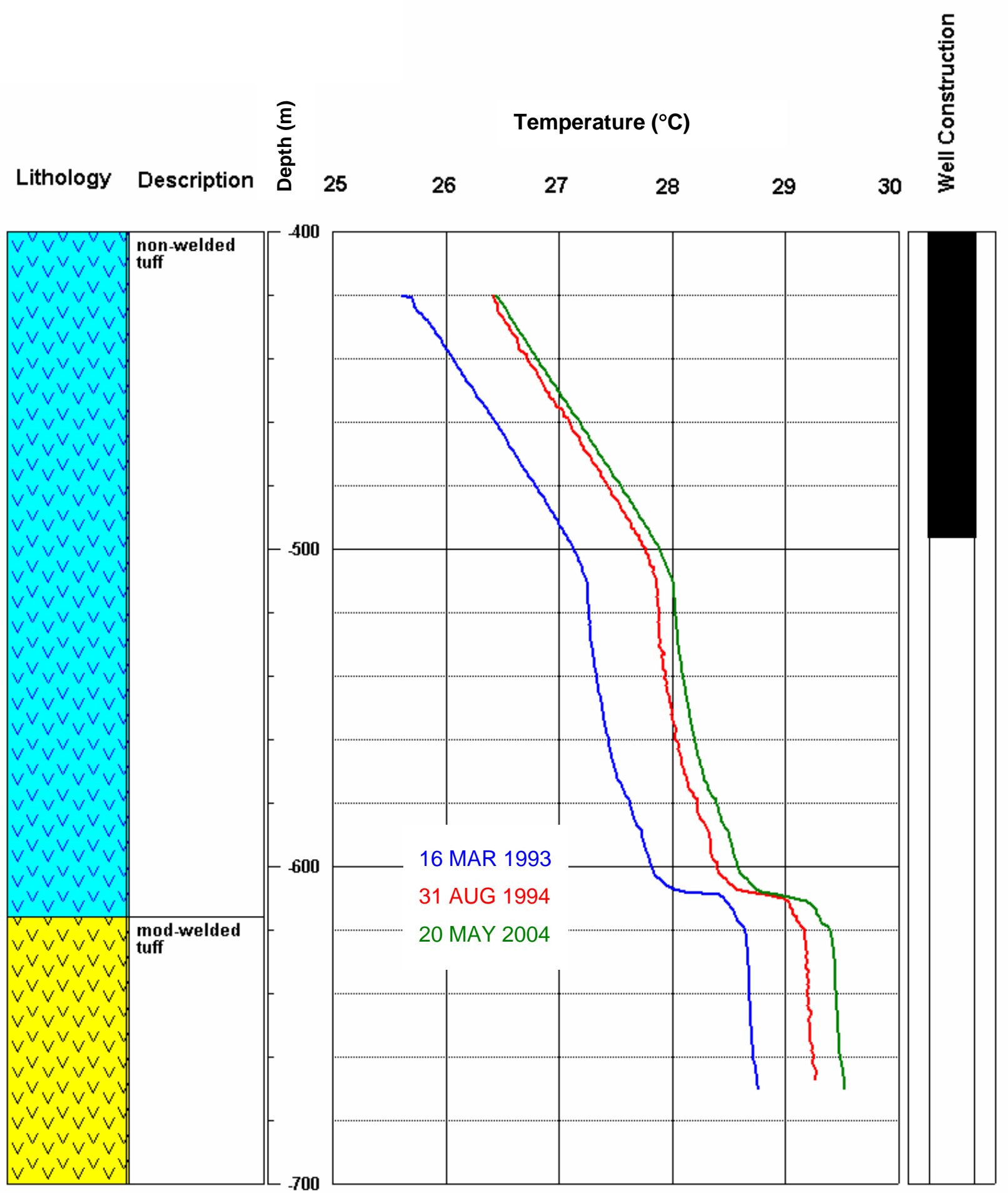

Figure 9. Temperature profiles from UE-18r obtained by Atlas Wireline Services on March 13, 1993, and DRI on August 31, 1994, and May 20, 2004. 
The initial DRI temperature profile was recorded on August 31, 1994, using DRI's Chemtool. A least-squares regression of the linear portion of the temperature profile above the base of the casing within the borehole yielded a geothermal gradient of $0.0175{ }^{\circ} \mathrm{C} \mathrm{m}^{-1}$. A previous temperature log run by Atlas on March 16, 1993, resulted in a similar profile yielding a geothermal gradient of $0.018{ }^{\circ} \mathrm{C} \mathrm{m}^{-1}$. The temperature log obtained by DRI using the PHASe temperature tool on May 20, 2004, resulted in a measured thermal gradient of $0.0182{ }^{\circ} \mathrm{C} \mathrm{m}^{-1}$. Using a thermal conductivity of $1.42 \mathrm{~mW} \mathrm{~m}^{-1}{ }^{\circ} \mathrm{C}^{-1}$ (Sass et al., 1987) combined with the measured thermal gradient results in heat flow values of $24.8 \mathrm{~mW} \mathrm{~m}^{-2}, 25.6 \mathrm{~mW} \mathrm{~m}^{-2}$, and $25.8 \mathrm{~mW} \mathrm{~m}^{-2}$, respectively, for the Chemtool, Atlas, and PHASe profiles.

The temperature profiles from UE-18r are remarkable for two additional reasons. First, an examination of the temperature profile indicates downward flow in the open borehole below the casing. This downward fluid flow is apparent from the deflection of the temperature profile. Fluid entering the borehole below the casing carries cooler water downward, masking the true thermal gradient and decreasing the apparent thermal gradient. At approximately $610 \mathrm{~m}$ below ground surface, the temperature in the borehole increases rapidly, increasing the apparent thermal gradient, indicating other, warmer fluids are entering the borehole and continuing to move downward along with the fluid from above, as indicted by the sharp decrease in apparent thermal gradient below $610 \mathrm{~m}$. In 1991, DRI and the USGS conducted thermal flow logging within UE-18r (Lyles et al., 1991) that indicated the presence of vertical flow within the borehole below the casing.

Second, UE-18r is the only borehole of the 13 previously existing temperature profiles deemed suitable for the determination of heat flow values, where two temperature logs were available, sufficiently separated in time, to verify the thermal stability of the borehole. Figure 9 shows thermal profiles for UE-18r conducted by Atlas Wireline Services on March 13, 1993, and by DRI on August 31, 1994. With the exception of an approximately $0.6^{\circ} \mathrm{C}$ difference between the absolute temperature values measured by the logs, the temperature profiles are remarkably similar. A cross plot of temperature values between the two logs (Figure 10) yields a slope of 0.9389 with a correlation coefficient of 0.999 , indicating a good correlation between the two temperature profiles over the portion of interest in the borehole. Heat flow calculated using a geothermal gradient of $0.018{ }^{\circ} \mathrm{C} \mathrm{m}^{-1}$, determined from the Atlas Wireline Services temperature profile, resulted in a heat flow value of $25.6 \mathrm{~mW} \mathrm{~m}^{-2}$, compared with a value of $24.8 \mathrm{~mW} \mathrm{~m}^{-2}$ using the DRI temperature profile obtained in 1994.

These heat flow values determined from the DRI Chemtool and Atlas Wireline Services temperature profiles are in good agreement, however, a cross plot of temperature values between the Atlas Wireline Service and the DRI PHASe profiles obtained on 20 May, 2004, yielded a slope of 1.001 , with a correlation coefficient of 0.999 , indicating a much better correlation between the Atlas Wireline Service and PHASe profiles compared with the Chemtool profile. Heat flow calculated using a geothermal gradient of $0.0182{ }^{\circ} \mathrm{C} \mathrm{m}^{-1}$, determined from the PHASe profile, resulted in a heat flow of $25.8 \mathrm{~mW} \mathrm{~m}^{-2}$, almost identical to that calculated using the Atlas temperature profile. However, it should also be noted that the difference in absolute temperature between DRI's Chemtool and PHASe temperature profiles is only about $0.1{ }^{\circ} \mathrm{C}$, compared with the more than one-half degree difference between the DRI temperature profiles and the Atlas Wireline Service profile. This agreement between DRI's temperature profiles is likely due to the two-point temperature calibration procedures conducted by DRI as an integral part of its temperature logging program. 


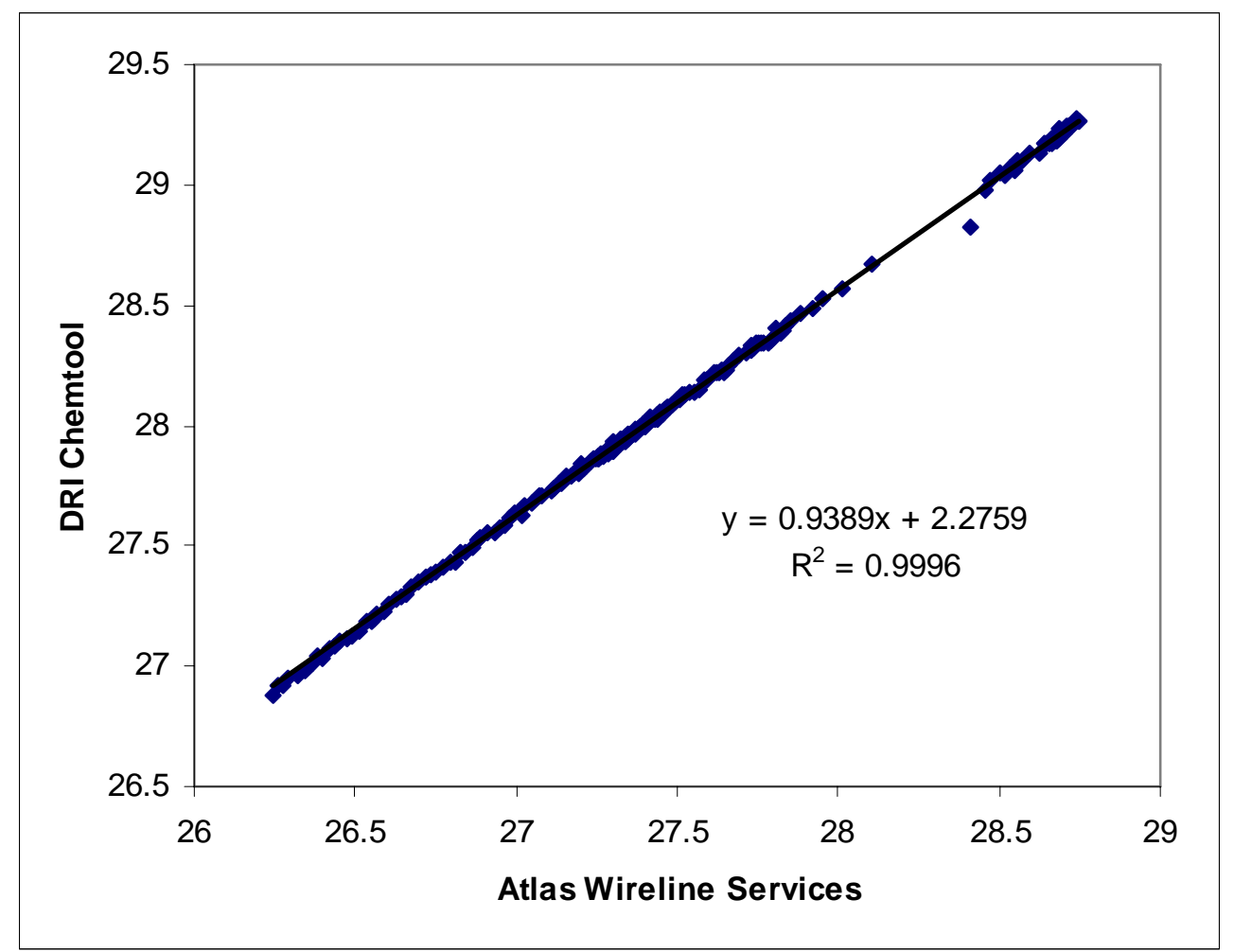

Figure 10. Cross plot of temperature values from DRI's Chemtool and Atlas Wireline Services temperature profiles obtained in UE-18r approximately 1 year and 5 months apart.

\section{UE-14b}

UE-14b (Figure 11) was completed in January 1984 to a depth of 1,121.7 m below ground surface. Casing, $33.97 \mathrm{~cm}$ in diameter, was cemented in the borehole to a depth of $625.1 \mathrm{~m}$ below ground surface. Depth to static water level in the well is $508 \mathrm{~m}$ below ground surface, resulting in approximately $117 \mathrm{~m}$ of fluid above the bottom of the casing in the borehole. The saturated portion of the borehole above the bottom of the casing is located almost entirely within a unit of welded tuff.

DRI obtained a temperature profile from UE-14b on August 21, 1991. The temperature profile was recorded using a thermistor contained within a stainless-steel housing manufactured by DRI personnel. On April 16, 2003, DRI obtained a second temperature profile from UE-14b using DRI's PHASe temperature probe. As shown in Figure 11, the temperature profiles, although obtained almost 12 years apart with different logging tools, appear strikingly similar. A cross plot of two temperature profiles yields a correlation coefficient $\left(R^{2}\right)$ of 0.9985 , with a slope of 0.9476 . The primary difference between the two profiles is the noisier quality of the earlier temperature profile. 


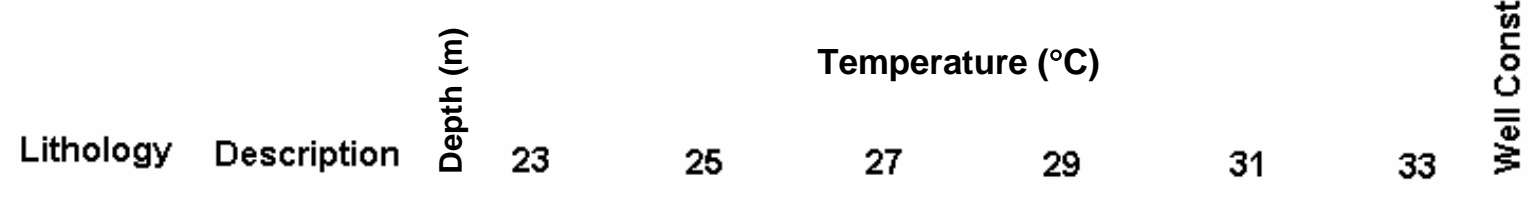

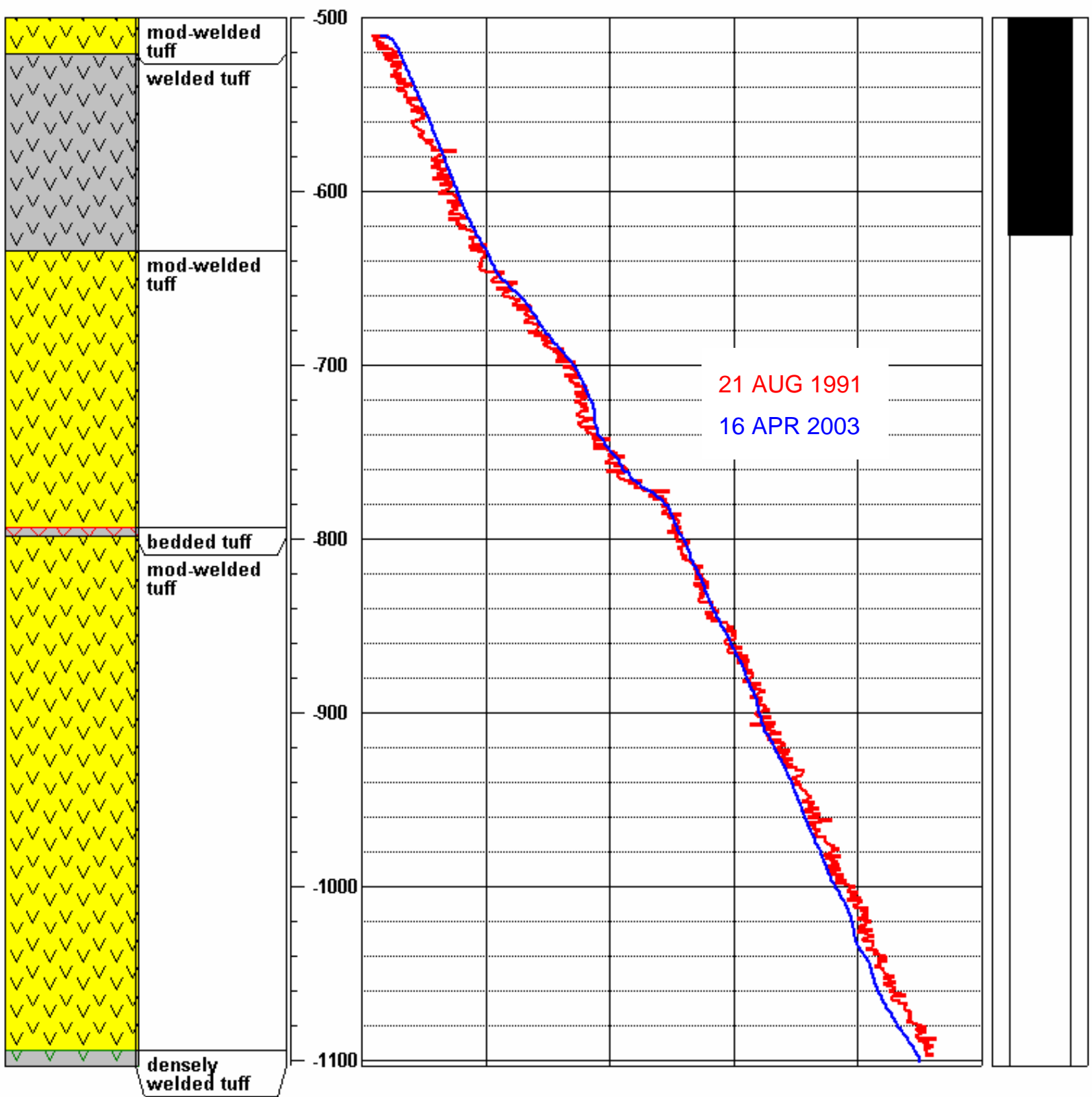

Figure 11. Temperature profiles, lithology, and well construction for borehole UE-14b. 
A least-squares regression of the linear portion of the earlier temperature profile from the top of the welded tuff unit, at $521.2 \mathrm{~m}$ below ground surface, to the base of the casing within the borehole yielded a geothermal gradient of $0.0118{ }^{\circ} \mathrm{C} \mathrm{m}^{-1}$. Using a thermal conductivity of $1.86 \mathrm{~W} \mathrm{~m}^{-1 \circ} \mathrm{C}^{-1}$ (Sass et al., 1987) combined with the measured thermal gradient results in a heat flow value of $21.9 \mathrm{~mW} \mathrm{~m}^{-2}$. A least-squares regression over the same interval in the temperature profile measured using DRI's PHASe temperature probe yielded a geothermal gradient of $0.0115{ }^{\circ} \mathrm{C} \mathrm{m}^{-1}$, resulting in a heat flow value of $21.4 \mathrm{~mW} \mathrm{~m}^{-2}$.

Additional features of interest in the temperature profile from UE-14b include the pronounced change in gradient at approximately $634.6 \mathrm{~m}$ below ground surface, which coincides with the contact between the welded tuff and the underlying moderately welded tuff. Below this increase in gradient, the presence of significant downward vertical flow within the borehole is readily apparent between approximately 700 and $770 \mathrm{~m}$ below ground surface, where downward flow within the borehole produces the typical concave upward signature (Ramey, 1962) seen in the temperature profile. Below approximately $800 \mathrm{~m}$ below ground surface, the thermal gradient again becomes linear with a value of $0.0123^{\circ} \mathrm{C} \mathrm{m}^{-1}$. As published by Sass et al. (1987), moderately welded tuff has a thermal conductivity of $1.78 \mathrm{~W} \mathrm{~m}^{-1}{ }^{\circ} \mathrm{C}^{-1}$, compared to the thermal conductivity of $1.86 \mathrm{~W} \mathrm{~m}^{-1}{ }^{\circ} \mathrm{C}^{-1}$ for welded tuff. Although, as mentioned previously, the two values are not statistically different using the thermal conductivity value for the moderately welded tuff for the lower portion of the profile results in a calculated heat flow value of $21.9 \mathrm{~mW} \mathrm{~m}^{-2}$, almost identical to the heat flow estimated in the welded tuff above the bottom of the casing. This would indicate the lack of significant vertical flow within the borehole below approximately $800 \mathrm{~m}$.

\section{HTH-1}

HTH-1 (Figure 12) was originally completed on June 10, 1961, and subsequently recompleted on August 20, 1962. HTH-1 was drilled to a depth of 1,282 m below ground surface. Casing, $27.94 \mathrm{~cm}$ in diameter, was cemented in the borehole to a depth of $475.9 \mathrm{~m}$ below ground surface. Below the 27.94-cm-diameter casing, 20.32-cm-diameter casing was placed to a depth of 1,131.1 m below ground surface. This 20.32-cm-diameter casing was perforated over five intervals between the depths of $582.2 \mathrm{~m}$ and $740.7 \mathrm{~m}$ below ground surface. Depth to static water level in the well is $447 \mathrm{~m}$ below ground surface, resulting in approximately $135 \mathrm{~m}$ of fluid above the top of the uppermost perforated interval in the borehole. The saturated portion of the borehole above the bottom of the casing is located almost entirely within a unit of volcanic tuff.

A least-squares regression of the linear portion of the temperature profile from $\mathrm{HTH}-1$, obtained by DRI on August 19, 1991, above the top of the uppermost perforated interval, yielded a geothermal gradient of $0.0179{ }^{\circ} \mathrm{C} \mathrm{m}^{-1}$. Using a thermal conductivity of $1.62 \mathrm{~W} \mathrm{~m}^{-1}{ }^{\circ} \mathrm{C}^{-1}$ (Sass et al., 1987) combined with the measured thermal gradient results in a heat flow value of $29.0 \mathrm{~mW} \mathrm{~m}^{-2}$. A least-squares regression over the same interval of the temperature profile obtained by DRI on April 22, 2003, yielded a geothermal gradient of $0.0168{ }^{\circ} \mathrm{C} \mathrm{m}^{-1}$, resulting in a heat flow value of $27.2 \mathrm{~mW} \mathrm{~m}^{-2}$.

The temperature profile obtained by DRI on August 19, 1991, was measured using the previously described thermistor within a stainless-steel housing. A cross-plot of the temperature profiles obtained on August 19, 1991, and April 22, 2003, results in a correlation coefficient of 
0.998 with a slope of 0.9377 . As with the comparison of the temperature profiles from UE-14b, the primary difference between the two profiles is the noisier nature of the older profile and the slight difference in slope of the temperature profiles. However, absolute temperature measured by the two profiles is very similar, with a difference of only about $0.1{ }^{\circ} \mathrm{C}$.
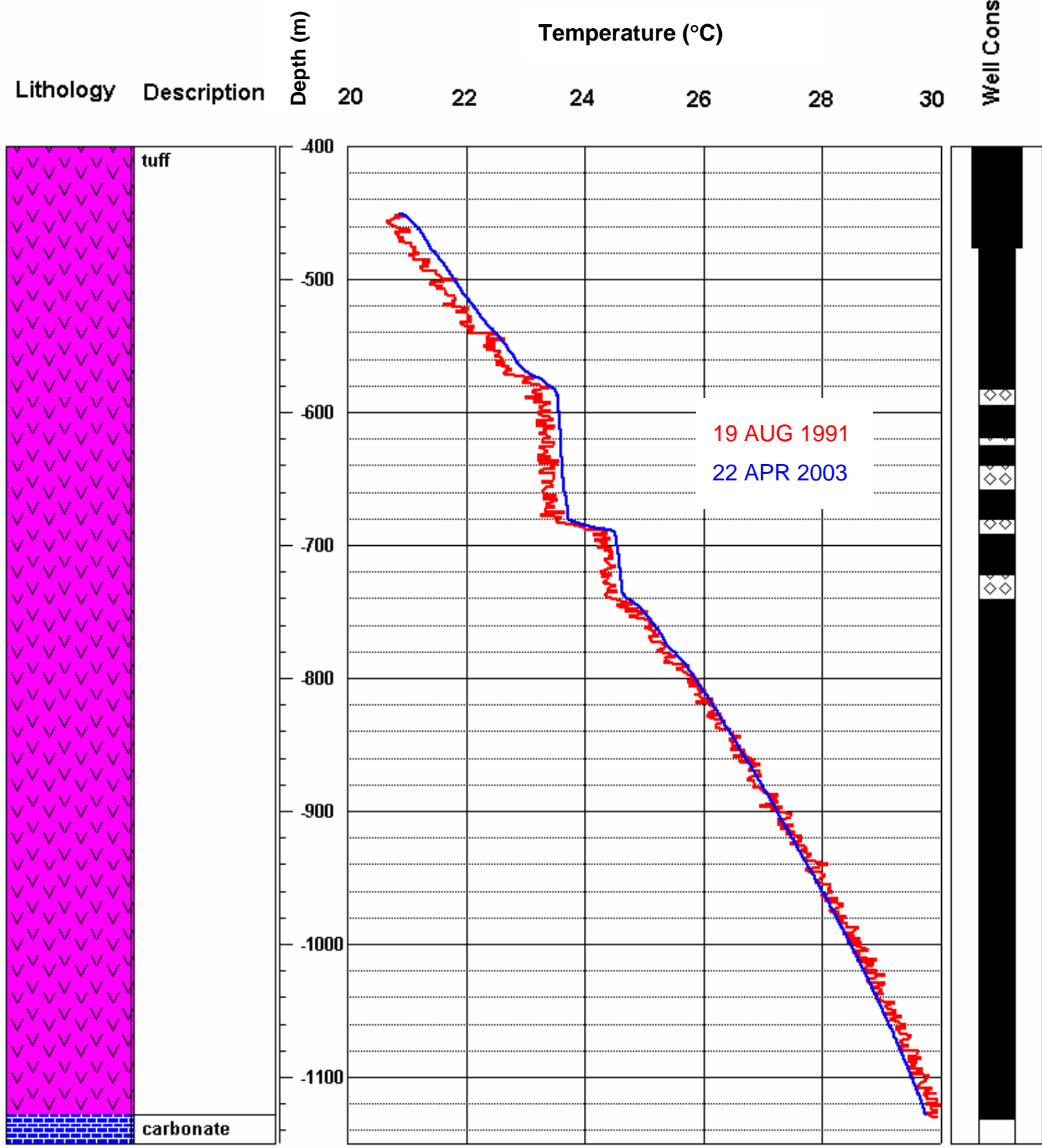

Figure 12. Temperature profiles, lithology, and well construction for borehole HTH-1. 
Intervals with extremely low-gradients correspond to depths of the perforations within HTH-1. Low gradients indicate the presence of significant vertical flow within the borehole between the perforated intervals. Although difficult to interpret, the temperature profile from HTH-1 would appear to indicate the flow within the borehole to be generally downward from the upper perforated interval to the lower perforated interval. However, significant horizontal flow within the tuff with the associated fluid mixing and lowering of apparent thermal conductivity may also result in the extremely low-gradient intervals measured in the temperature profile from HTH-1. Thermal flowmeter measurements at HTH-1 (Lyles et al., 1991) were inconclusive. Also of interest in the temperature profiles from HTH-1 is the apparent convex upward curvature in the profile below the perforations. Several factors may account for this curvature in the profile. Upward fluid flow, either within the casing, in the annular space between the casing and the borehole, or in the formation outside the borehole, could produce the convex upward curvature observed in the profile. Also, a gradual increase in the thermal conductivity of the tuff unit with depth, either through compaction or a gradual increase in welding (density), could produce a gradual decrease in thermal gradient. Information for discerning which process is responsible for the convex upward profile is unavailable.

\section{TW-7}

TW-7 (Figure 13) was completed on June 30, 1954, to a depth of $692.5 \mathrm{~m}$ below ground surface. Casing, $30.48 \mathrm{~cm}$ in diameter, was cemented in the borehole to a depth of $613.9 \mathrm{~m}$ below ground surface. Depth to static water level in the well is $499.6 \mathrm{~m}$ below ground surface, resulting in approximately $114 \mathrm{~m}$ of fluid above the bottom of the casing in the borehole. The saturated portion of the borehole above the bottom of the casing is located almost entirely within a unit of volcanic tuff.

A temperature profile for TW-7 was conducted by DRI on March 20, 1996, and terminated at $601.8 \mathrm{~m}$ below ground surface, $12.1 \mathrm{~m}$ above the base of the casing at $613.9 \mathrm{~m}$. A least-squares regression of the linear portion of the temperature profile obtained using DRI's Chemtool yielded a geothermal gradient of $0.0122{ }^{\circ} \mathrm{C} \mathrm{m}^{-1}$. Using a thermal conductivity of $1.62 \mathrm{~W} \mathrm{~m}^{-1}{ }^{\circ} \mathrm{C}^{-1}$ (Sass et al., 1987) combined with the measured thermal gradient results in a heat flow value of $19.8 \mathrm{~mW} \mathrm{~m}^{-2}$.

On April 22, 2004, a second temperature profile was run in TW-7 using DRI's PHASe temperature probe. This profile yielded a geothermal gradient of $0.0112^{\circ} \mathrm{C} \mathrm{m}^{-1}$, resulting in a calculated heat flow value of $18.1 \mathrm{~mW} \mathrm{~m}^{-2}$. A cross-plot of the two temperature profiles results in a correlation coefficient of 0.999 with a slope of 0.9209 . Aside from the almost $1{ }^{\circ} \mathrm{C}$ difference in the absolute temperature measured by the two temperature profiles, the profiles are very similar.

\section{UE-5n}

UE-5n (Figure 14) was originally completed on July 1, 1976, to a depth of $514.2 \mathrm{~m}$ below ground surface. Casing, $25.4 \mathrm{~cm}$ in diameter, was cemented in the borehole to a depth of $464.2 \mathrm{~m}$ below ground surface; however, the wiper plug used to push the cement out the bottom of the casing was never drilled out, effectively sealing the bottom of the casing string. The casing was perforated between the depths of $219.5 \mathrm{~m}$ and $222.5 \mathrm{~m}$ below ground surface. Depth to static water level in the well is $214.5 \mathrm{~m}$ below ground surface. The saturated portion of the borehole is located entirely within alluvium. 

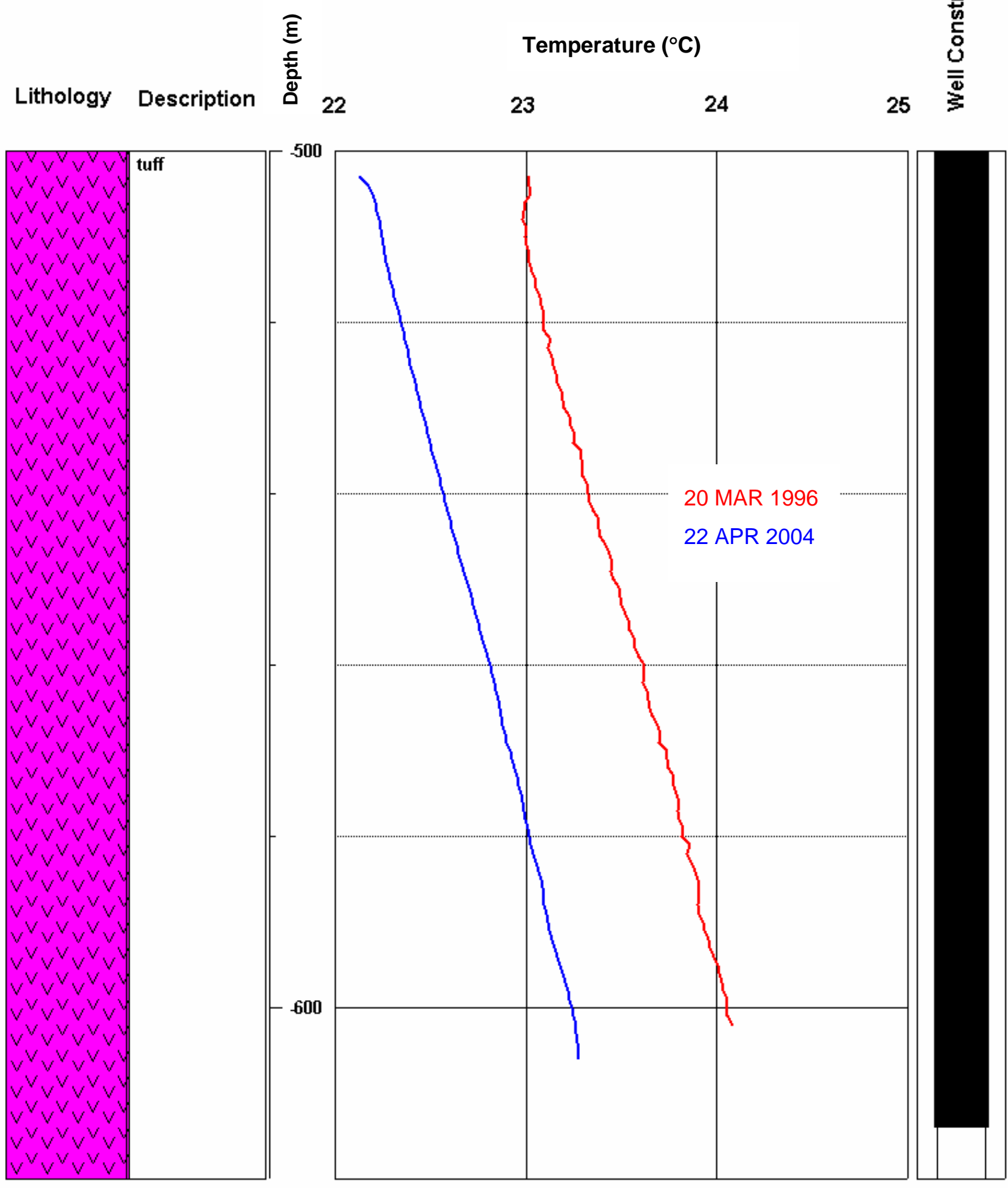

Figure 13. Temperature profiles, lithology, and well construction for borehole TW-7. 

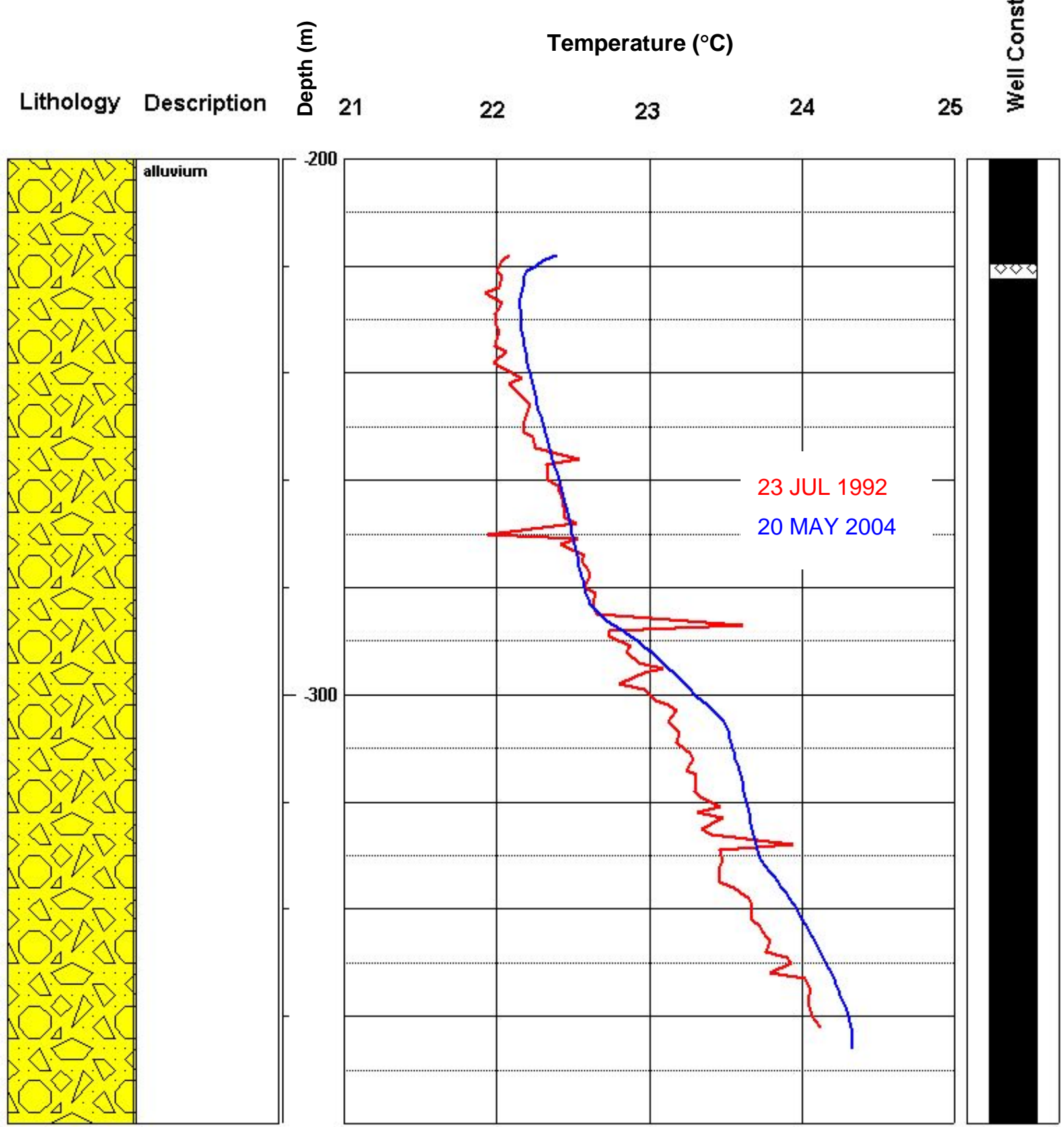

Figure 14. Temperature profiles, lithology, and well construction for borehole UE-5n. 
DRI conducted the initial temperature profile from UE-5n on July 23, 1992. The temperature log could not be completed below approximately $361 \mathrm{~m}$ below ground surface because of an obstruction in the borehole. A least-squares regression of the temperature profile above the obstruction yielded a geothermal gradient of $0.0165{ }^{\circ} \mathrm{C} \mathrm{m}^{-1}$. Using a thermal conductivity of $1.2 \mathrm{~W} \mathrm{~m}^{-1}{ }^{\circ} \mathrm{C}^{-1}$ (Gillespie et al., 1995) combined with the measured thermal gradient results in a heat flow value of $19.8 \mathrm{~mW} \mathrm{~m}^{-2}$.

A subsequent temperature profile was obtained by DRI on May 20, 2004, using DRI's PHASe temperature logging tool. This profile is similar to the initial profile, although the earlier profile is extremely noisy. Three conspicuous breaks in gradient are apparent in the later profile. These breaks may be due to variations in lithology of the material comprising various intervals of the alluvium, however, the average gradient of the later profile over the logged interval is $0.0174{ }^{\circ} \mathrm{C} \mathrm{m}^{-1}$, which is almost identical to the gradient determined from the earlier profile. The gradient of $0.0174{ }^{\circ} \mathrm{C} \mathrm{m}^{-1}$ combined with a thermal conductivity of $1.2 \mathrm{~W} \mathrm{~m}^{-1}{ }^{\circ} \mathrm{C}^{-1}$ yields a heat flow value of $20.9 \mathrm{~mW} \mathrm{~m}^{-2}$.

\section{PM-1}

PM-1 (Figure 15) was completed in June 1963 and recompleted in May 1964 to a depth of 2,395.0 $\mathrm{m}$ below ground surface. Casing, $27.3 \mathrm{~cm}$ in diameter, was cemented in the borehole to a depth of 2,299.1 m below ground surface. Depth to static water level in the well is approximately $640 \mathrm{~m}$ below ground surface, resulting in approximately 1,659.1 $\mathrm{m}$ of fluid above the bottom of the casing in the borehole. The saturated portion of the borehole above the bottom of the casing is located within inter-bedded units of volcanic tuff of various thickness. DRI conducted the earlier temperature profile from PM-1, using DRI's Chemtool, on August 3, 1994. The temperature log could not be completed below approximately 1,067.4 m below ground surface because of the limited length (approximately 3,500 ft) of DRI's geophysical wireline.

The thickness-weighted harmonic mean of the thermal conductivities (Sass et al., 1987) of the volcanic units encountered by the borehole between the static water level in the borehole and the contact between the bedded tuff and nonwelded tuff units located at a depth of $964.4 \mathrm{~m}$ below ground surface was calculated to yield a composite thermal conductivity of $1.78 \mathrm{~W} \mathrm{~m}^{-1}{ }^{\circ} \mathrm{C}^{-1}$. The average geothermal gradient over this interval from the earlier profile is $0.0271^{\circ} \mathrm{C} \mathrm{m}^{-1}$, resulting in a heat flow value of $48.2 \mathrm{~mW} \mathrm{~m}^{-2}$. Using the temperature profile obtained using DRI's PHASe temperature probe over the same interval on August 27, 2002, resulted in a geothermal gradient of $0.0286{ }^{\circ} \mathrm{C} \mathrm{m}^{-1}$, yielding a heat flow of $51.0 \mathrm{~W} \mathrm{~m}{ }^{-2}$. A cross plot of temperature data from the earlier and later temperature profiles from borehole PM-1 yields a correlation coefficient of 1.0 with a slope of 1.102. Although the correlation coefficient is excellent, the difference in slope indicates a significant error in the temperature measurement from the earlier temperature profile, resulting in a considerable error in the calculated heat flow.

PM-1 is of particular interest because it is the deepest continuously cased borehole at the NTS. Using the PHASe temperature profile, the average geothermal gradient over the entire logged interval is $0.021^{\circ} \mathrm{C} \mathrm{m}^{-1}$. Combined with a thickness-weighted harmonic mean of the thermal conductivity of $1.73 \mathrm{~W} \mathrm{~m}^{-1}{ }^{\circ} \mathrm{C}^{-1}$ for the lithologies (Sass et al., 1987) where temperature measurements were obtained results in a heat flow value of $36.3 \mathrm{~mW} \mathrm{~m}^{-2}$. Examination of the temperature profile from PM-1 reveals four major breaks in the geothermal gradient. The uppermost linear section, from the water level to approximately $965 \mathrm{~m}$, is composed of various 

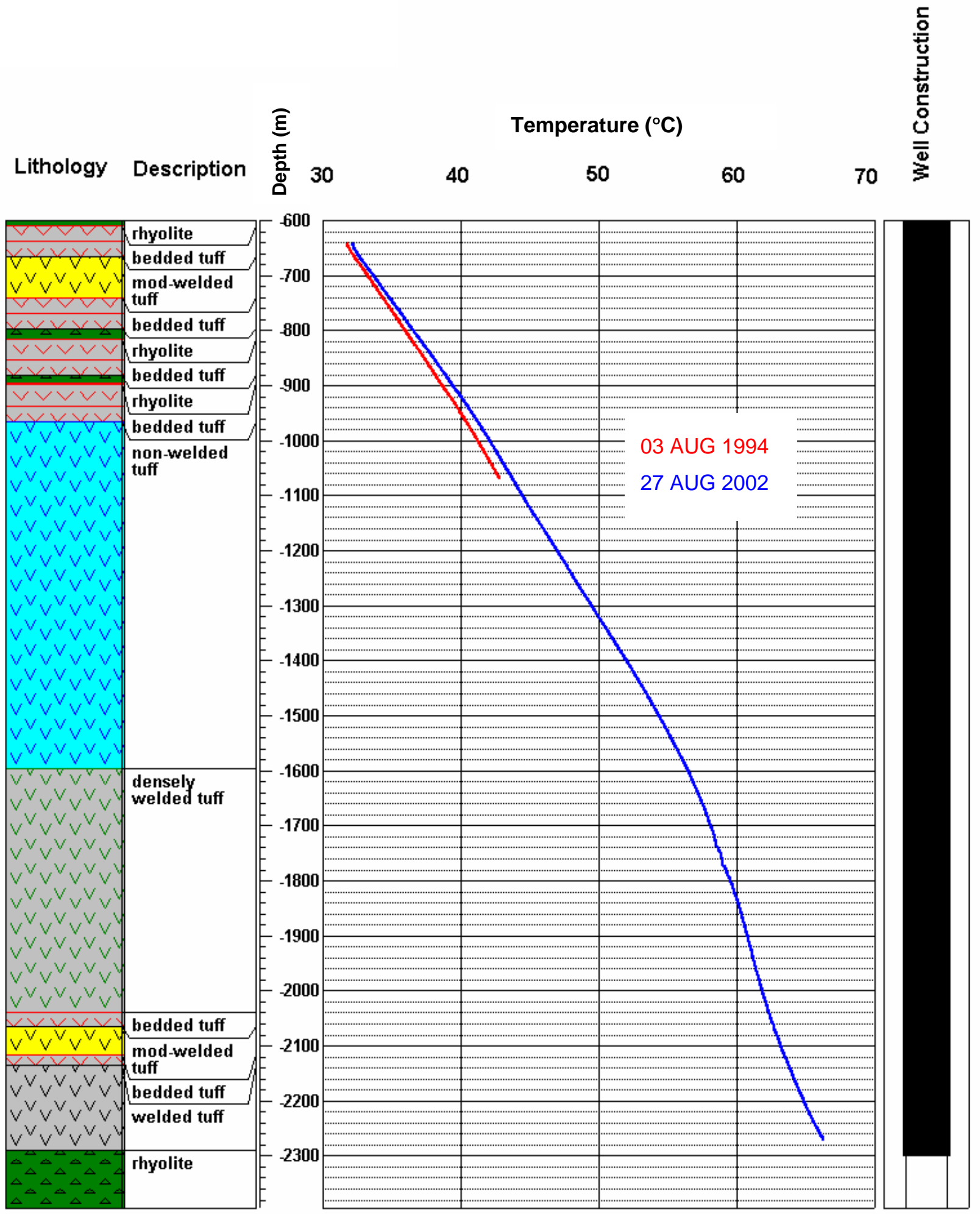

Figure 15. Temperature profiles, lithology, and well construction for borehole PM-1. 
tuff units. Below this interval are a nonwelded tuff unit (965 to 1,595 m) followed by a unit of densely welded tuff (1,595 to 2,040 m); the bottom portion of the borehole consists of bedded, moderately welded, and welded tuffs (2,040 to 2,270 m). Although the overall heat flow value determined from the PM-1 temperature profile is $36.2 \mathrm{~mW} \mathrm{~m}^{-2}$, if the heat flow values of these four intervals are determined, a definite decrease in heat flow with depth is apparent (Figure 16a).

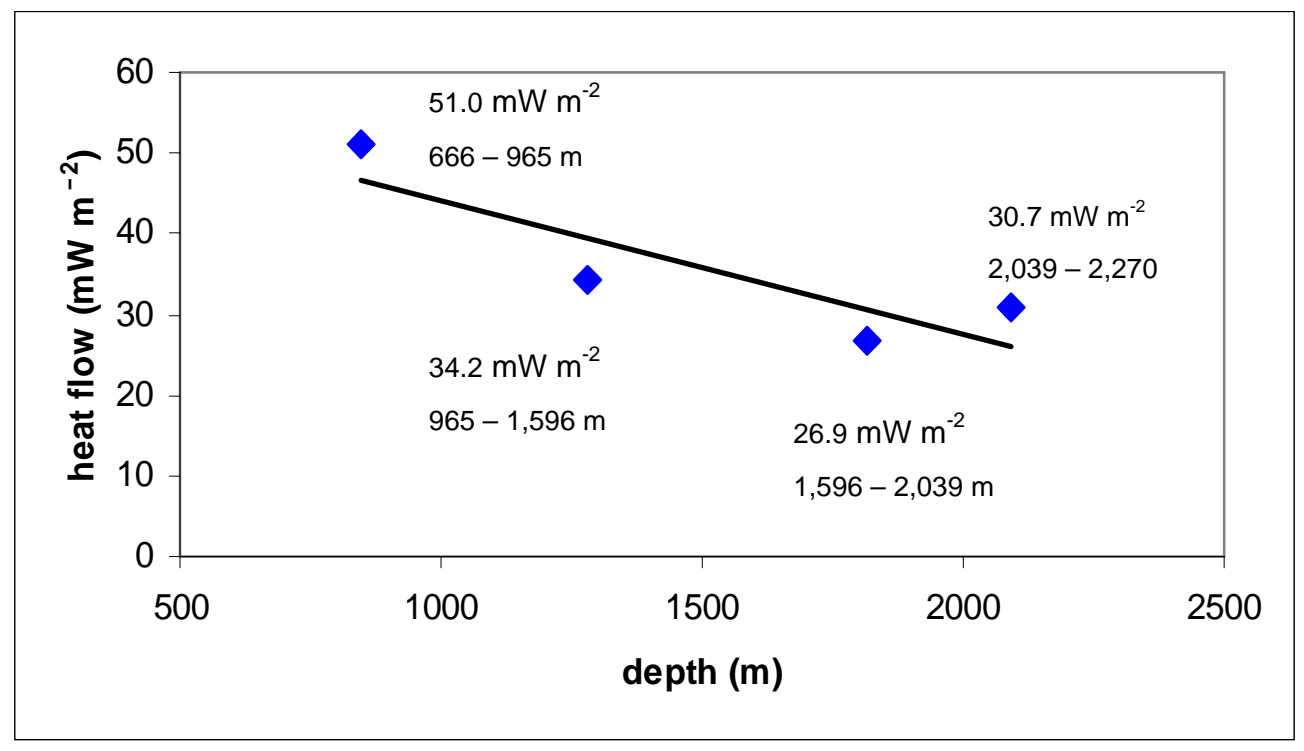

Figure 16a. Decrease in calculated heat flow with depth at PM-1.

This apparent decrease in heat flow with depth may be attributable to several factors. The one-dimensional analysis of heat flux in the vicinity of PM-1 did not allow for depth-dependent changes in thermal conductivity for a given lithologic unit. However, thermal conductivity may increase due to compaction at depth. By using erroneously low thermal conductivity values, calculated heat flow estimates for progressively deeper units are less than what they would otherwise be. Alternatively, it should be noted that the lowest heat flow values were calculated for the unit of densely welded tuff where horizontal groundwater flow would most likely occur. Horizontal flow would also produce a decrease in the apparent measured thermal gradient within the densely welded tuff unit.

As discussed earlier, Sass et al. (1987) measured thermal conductivities of 135 specimens of volcanic tuffs and 13 specimens of Paleozoic carbonate rocks obtained from core samples retrieved from saturated portions of boreholes drilled at the Yucca Mountain Site. A comparison of the depth from which the sample was obtained to the measured thermal conductivity of the sample (Figure 16b) does indeed show a trend of increased thermal conductivity with depth for the 135 volcanic tuff samples. 


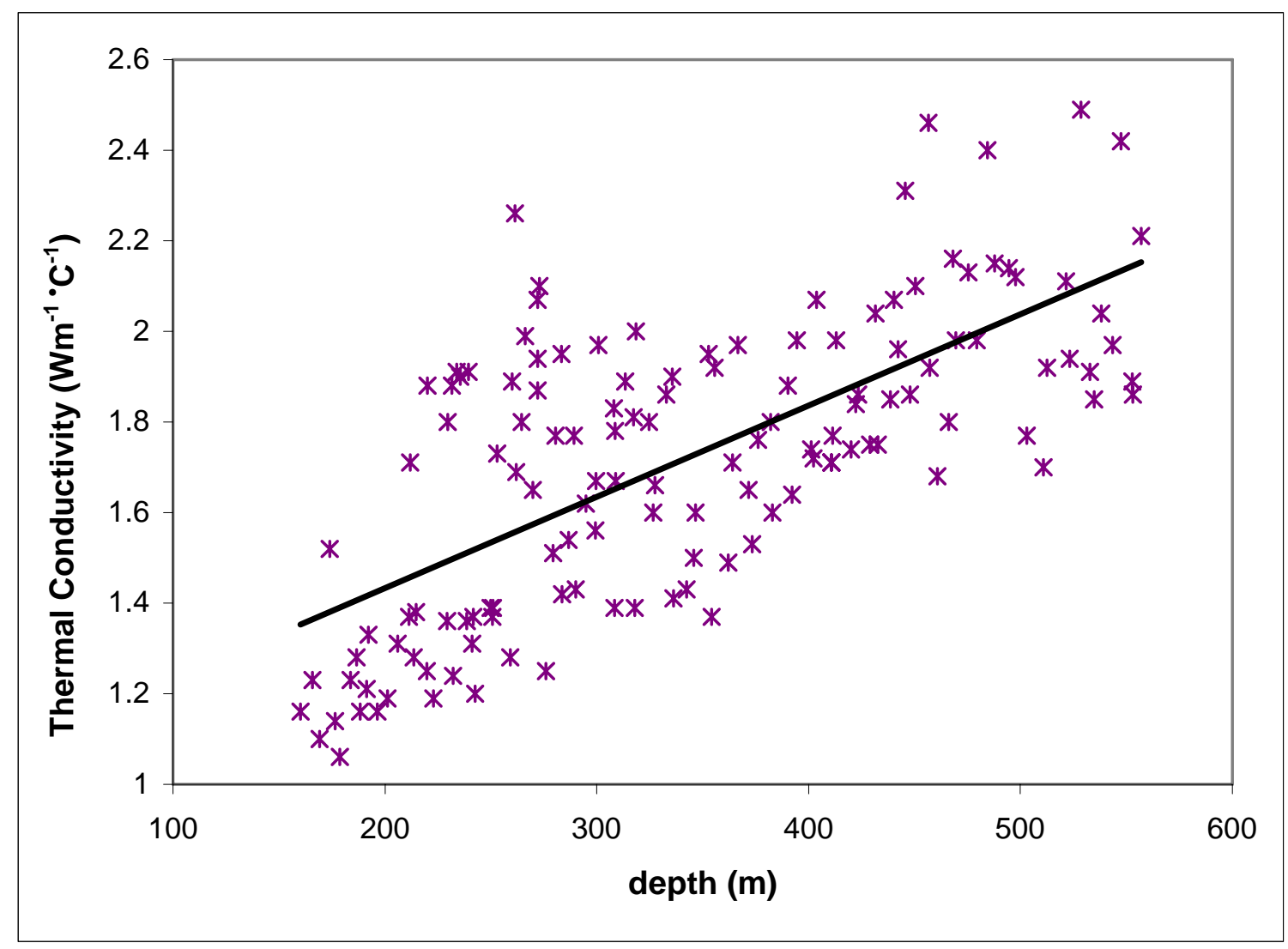

Figure 16b. Increase in thermal conductivity with depth for volcanic lithologies (Sass et al., 1987).

\section{UE-11}

UE-1l (Figure 17) was completed on August 12, 1972, to a depth of $693.4 \mathrm{~m}$ below ground surface. Casing, $33.97 \mathrm{~cm}$ in diameter, was cemented in the borehole to a depth of $218.2 \mathrm{~m}$ below ground surface. Depth to static water level in the well is $157.3 \mathrm{~m}$ below ground surface, resulting in approximately $60 \mathrm{~m}$ of fluid above the bottom of the casing in the borehole. The saturated portion of the borehole above the bottom of the casing is located entirely within an argillite.

The temperature profile for UE-1l was obtained by DRI on January 28, 2002. A leastsquares regression of the linear portion of the temperature profile above the base of the casing in the borehole yielded a geothermal gradient of $0.0306{ }^{\circ} \mathrm{C} \mathrm{m}^{-1}$. Using a thermal conductivity of $3.3 \mathrm{~W} \mathrm{~m}^{-1}{ }^{\circ} \mathrm{C}^{-1}$ (Johnston et al., 1981) combined with the measured thermal gradient results in a heat flow value of $101.0 \mathrm{~mW} \mathrm{~m}^{-2}$.

The decrease in thermal gradient below the base of the casing in UE-1l may indicate the possible presence of downward flow within the borehole below the casing, or possibly horizontal flow within the formation penetrated by the borehole. A change in lithology to an interval of higher thermal conductivity would also result in the decrease in the measured thermal gradient. 

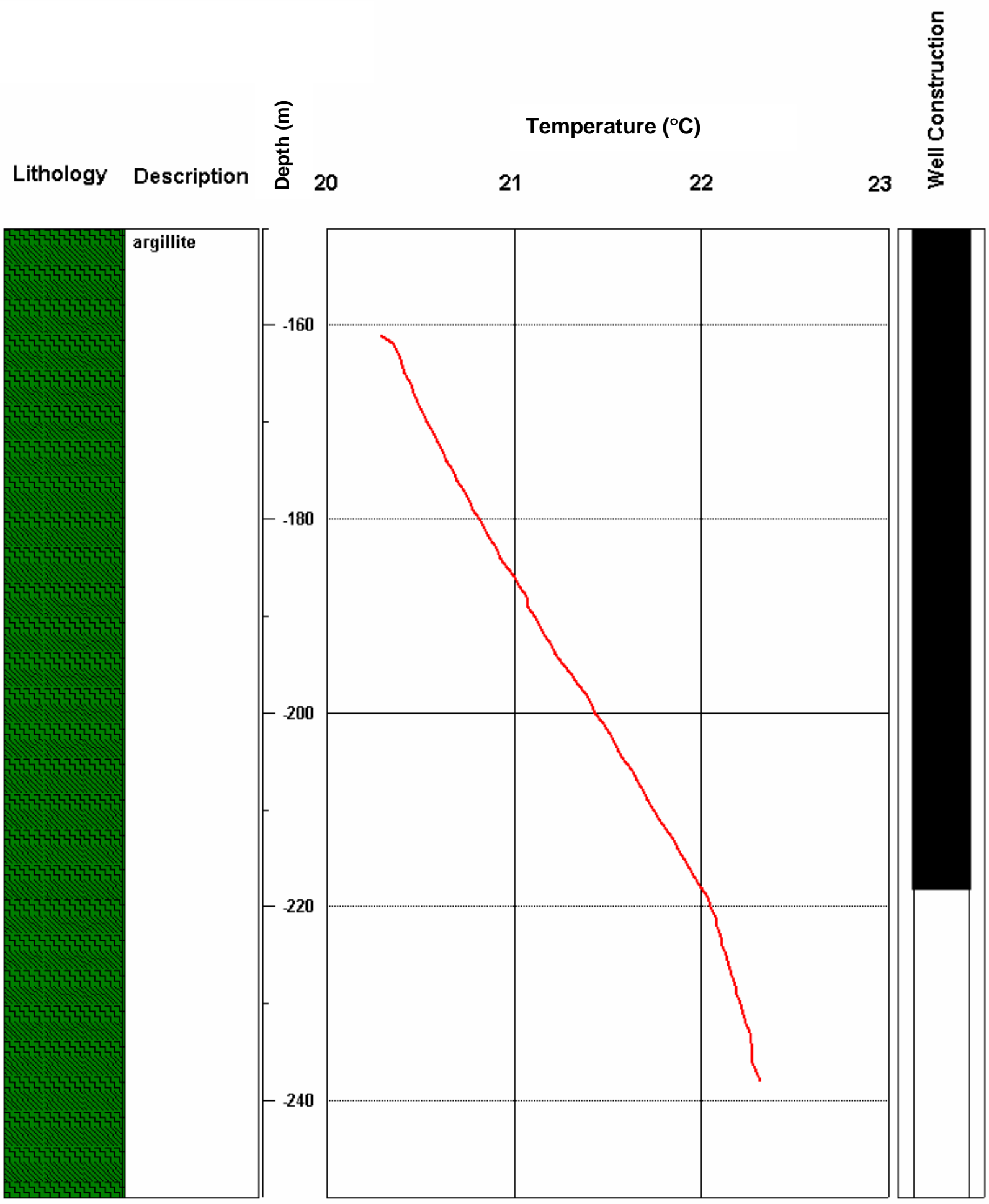

Figure 17. Temperature profile, lithology, and well construction for borehole UE-1l. 


\section{UE-16f}

UE-16f (Figure 18) was completed on September 27, 1977, to a depth of $450.8 \mathrm{~m}$ below ground surface. Casing, $24.45 \mathrm{~cm}$ in diameter, was cemented in the borehole to a depth of $394.1 \mathrm{~m}$ below ground surface. Depth to static water level in the well is $112 \mathrm{~m}$ below ground surface, resulting in approximately $282 \mathrm{~m}$ of fluid above the bottom of the casing in the borehole. The saturated portion of the borehole above the bottom of the casing is located entirely within an argillite.

On May 2, 1994, a temperature profile was obtained by LLNL in borehole UE-16f. A least-squares regression of the linear portion of the temperature profile above the base of the casing in the borehole yielded a geothermal gradient of $0.0293^{\circ} \mathrm{C} \mathrm{m}^{-1}$. Using a thermal conductivity of $3.3 \mathrm{~W} \mathrm{~m}^{-1}{ }^{\circ} \mathrm{C}^{-1}$ (Johnston et al., 1981) combined with the measured thermal gradient results in a heat flow value of $96.7 \mathrm{~mW} \mathrm{~m}^{-2}$. A least-squares regression over the same interval of the temperature profile obtained by DRI on April 16, 2003, yielded a geothermal gradient of $0.025^{\circ} \mathrm{C} \mathrm{m}^{-1}$, resulting in a heat flow value of $82.5 \mathrm{~mW} \mathrm{~m}^{-2}$.

A cross plot of the temperature profiles from UE-16f obtained on May 2, 1994, and April 16, 2003, result in a correlation coefficient of 0.884 with a slope of 0.8558 . The slope of 0.8558 indicates a significant error in the response of the temperature probe used to obtain the earlier temperature profile. This error in temperature measurement resulted in a difference in geothermal gradient measured by the two profiles, yielding a significant change in the calculated heat flow. It may also be noted that the earlier temperature is much noisier than the profile obtained in April 2003.

The decrease in thermal gradient below the base of the casing in UE-16f may indicate the possible presence of downward flow within the borehole below the casing, or possibly horizontal flow within the formation outside the borehole.

\section{UE-17a}

UE-17a (Figure 19) was completed in July 1976 and recompleted in September 1976 to a depth of $370 \mathrm{~m}$ below ground surface. Casing, $11.43 \mathrm{~cm}$ in diameter, was cemented in the borehole to a depth of $368.8 \mathrm{~m}$ below ground surface. Depth to static water level in the well is $193.5 \mathrm{~m}$ below ground surface, resulting in approximately $175 \mathrm{~m}$ of fluid above the bottom of the casing in the borehole. The saturated portion of the borehole above the bottom of the casing is located entirely within a quartzite.

The earlier temperature profile for UE-17a was conducted by LLNL on May 2, 1994. Although the borehole is cased, the temperature profile from UE-17a appears to indicate downward flow below approximately $250 \mathrm{~m}$ below ground surface. This flow most likely occurs in the annular space between the casing and the borehole and may be the result of an inadequate seal between the casing and the borehole. In boreholes drilled in less competent formations, such as alluvium or nonwelded tuffs, one would expect slumping of the borehole to fill in and seal the annular space between the borehole and the casing. However, a borehole drilled through quartzite would probably retain an open annular space between the casing and the borehole. 

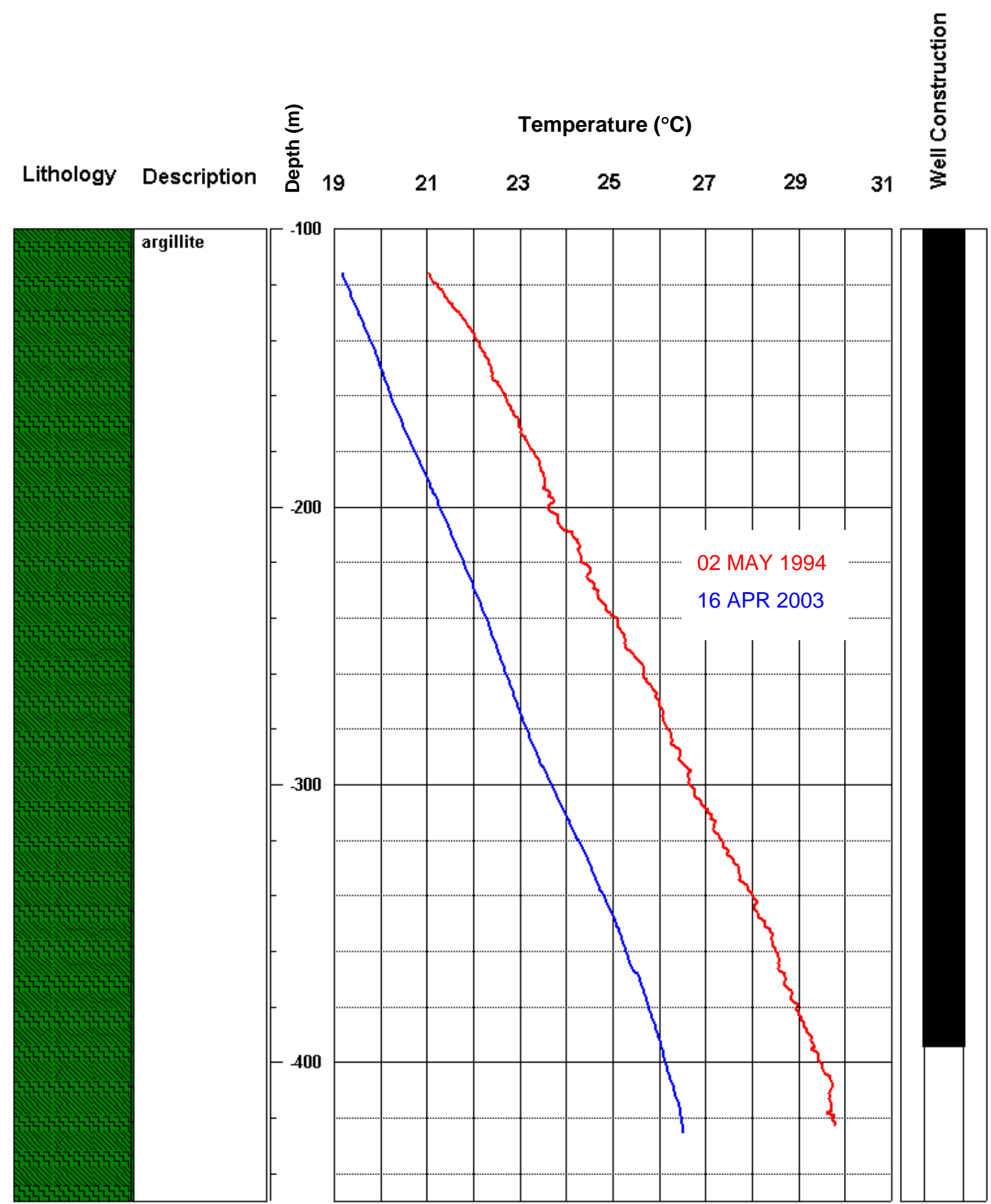

Figure 18. Temperature profile, lithology, and well construction for borehole UE-16f. 

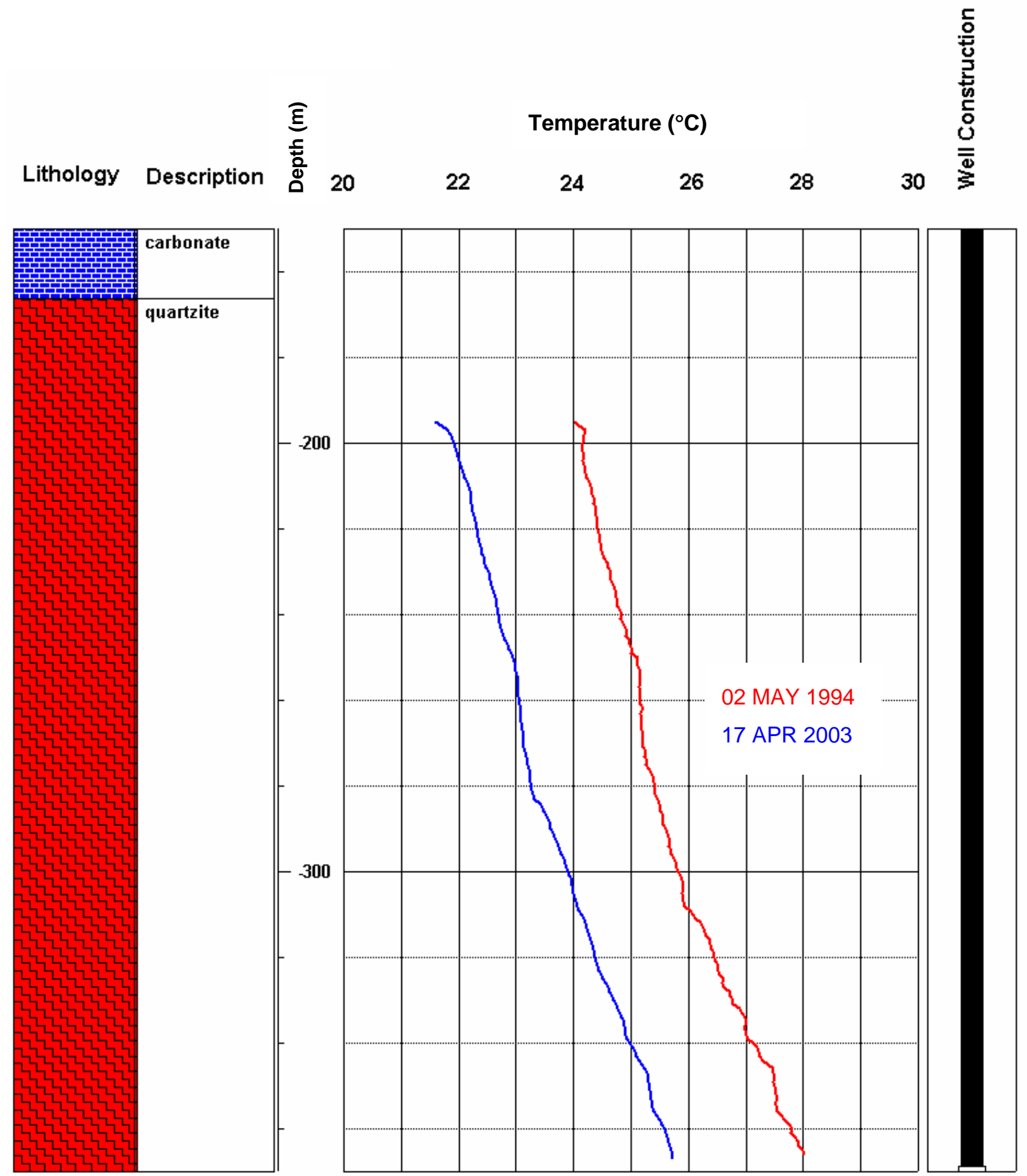

Figure 19. Temperature profiles, lithology, and well construction for borehole UE-17a. 
A least-squares regression of the linear portion of the temperature profile above the portion of the temperature profile that appears to be disturbed by flow in the annulus yielded a geothermal gradient of $0.0181{ }^{\circ} \mathrm{C} \mathrm{m}^{-1}$. Johnston et al. (1981) published thermal conductivity values for quartzite ranging from 4.5 to $7.1 \mathrm{~W} \mathrm{~m}^{-1}{ }^{\circ} \mathrm{C}^{-1}$. Combined with the measured gradient of $0.018{ }^{\circ} \mathrm{C} \mathrm{m}^{-1}$, these thermal conductivity values would result in a range of heat flow values from 81.4 to $128.5 \mathrm{~mW} \mathrm{~m}^{-2}$. Using an average thermal conductivity of $5.8 \mathrm{~W} \mathrm{~m}^{-1}{ }^{\circ} \mathrm{C}^{-1}$ combined with the measured thermal gradient results in a heat flow value of $105.0 \mathrm{~mW} \mathrm{~m}^{-2}$. A least-squares regression over the same interval of the temperature profile obtained by DRI on April 17, 2003, yielded a geothermal gradient of $0.019{ }^{\circ} \mathrm{C} \mathrm{m}^{-1}$ that when combined with an average thermal conductivity of $5.8 \mathrm{~W} \mathrm{~m}^{-1}{ }^{\circ} \mathrm{C}^{-1}$, resulted in a heat flow value of $110.2 \mathrm{~mW} \mathrm{~m}^{-2}$.

A cross plot of the temperature profiles from UE-17a obtained on May 2, 1994, and April 17, 2003, results in a correlation coefficient of 0.994 with a slope of 0.9906 . The correlation coefficient is excellent, and the slope of 0.9906 indicates a small error in the response of the temperature probe used to obtain the earlier temperature profile, however, the difference in absolute temperature between the two profiles is about $2{ }^{\circ} \mathrm{C}$.

\section{UE-2ce}

UE-2ce (Figure 20) was completed on January 25, 1977, to a depth of $502.92 \mathrm{~m}$ below ground surface. Casing, $21.0 \mathrm{~cm}$ in diameter, was cemented in the borehole to a depth of $495 \mathrm{~m}$ below ground surface. Depth to static water level in the well is $441.5 \mathrm{~m}$ below ground surface, resulting in approximately $53 \mathrm{~m}$ of fluid above the bottom of the casing in the borehole. The saturated portion of the borehole above the bottom of the casing is located entirely within Paleozoic carbonate rock.

The temperature profile for UE-2ce was conducted by DRI on January 28, 2002. The temperature log was stopped at $459 \mathrm{~m}$ below ground surface to prevent exiting the access tubing for the well. A least-squares regression of the linear portion of the temperature profile yielded a geothermal gradient of $0.0017^{\circ} \mathrm{C} \mathrm{m}^{-1}$. Using a thermal conductivity of $5.0 \mathrm{~W} \mathrm{~m}^{-1}{ }^{\circ} \mathrm{C}^{-1}$ (Sass et al., 1987) combined with the measured thermal gradient results in a heat flow value of $8.5 \mathrm{~mW} \mathrm{~m}^{-2}$.

The extremely low heat flow value estimated from the temperature profile from UE-2ce suggests significant horizontal flow within the carbonate aquifer has effectively increased the apparent thermal conductivity of the aquifer.

\section{Amargosa Test Hole \#1 and Amargosa Test Hole \#2}

Amargosa Test Hole \#1 (ATH1) and Amargosa Test Hole \#2 (ATH2) are located southwest of the NTS (Figure 3). The two boreholes are located approximately $123 \mathrm{~m}$ from one another.

ATH1 (Figure 21) was completed on August 12, 1966, to a depth of $311.5 \mathrm{~m}$ below ground surface. Casing, $24.4 \mathrm{~cm}$ in diameter, was cemented in the borehole to a depth of $228.6 \mathrm{~m}$ below ground surface. The bottom $16.8 \mathrm{~m}$ of this casing was perforated. Depth to static water level in the well is $14 \mathrm{~m}$ below ground surface, resulting in approximately $197.8 \mathrm{~m}$ of fluid above the top of the perforated casing in the borehole. 


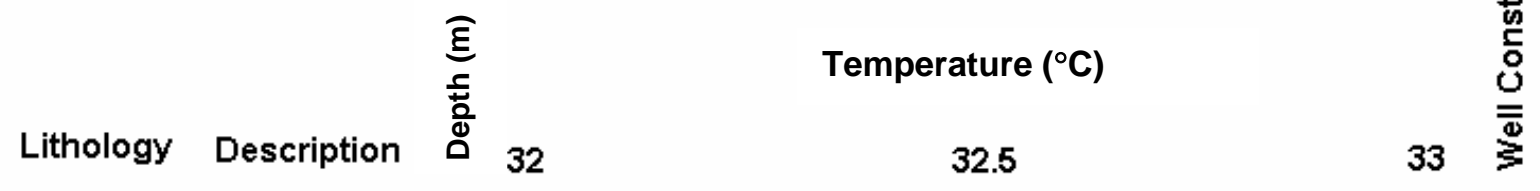

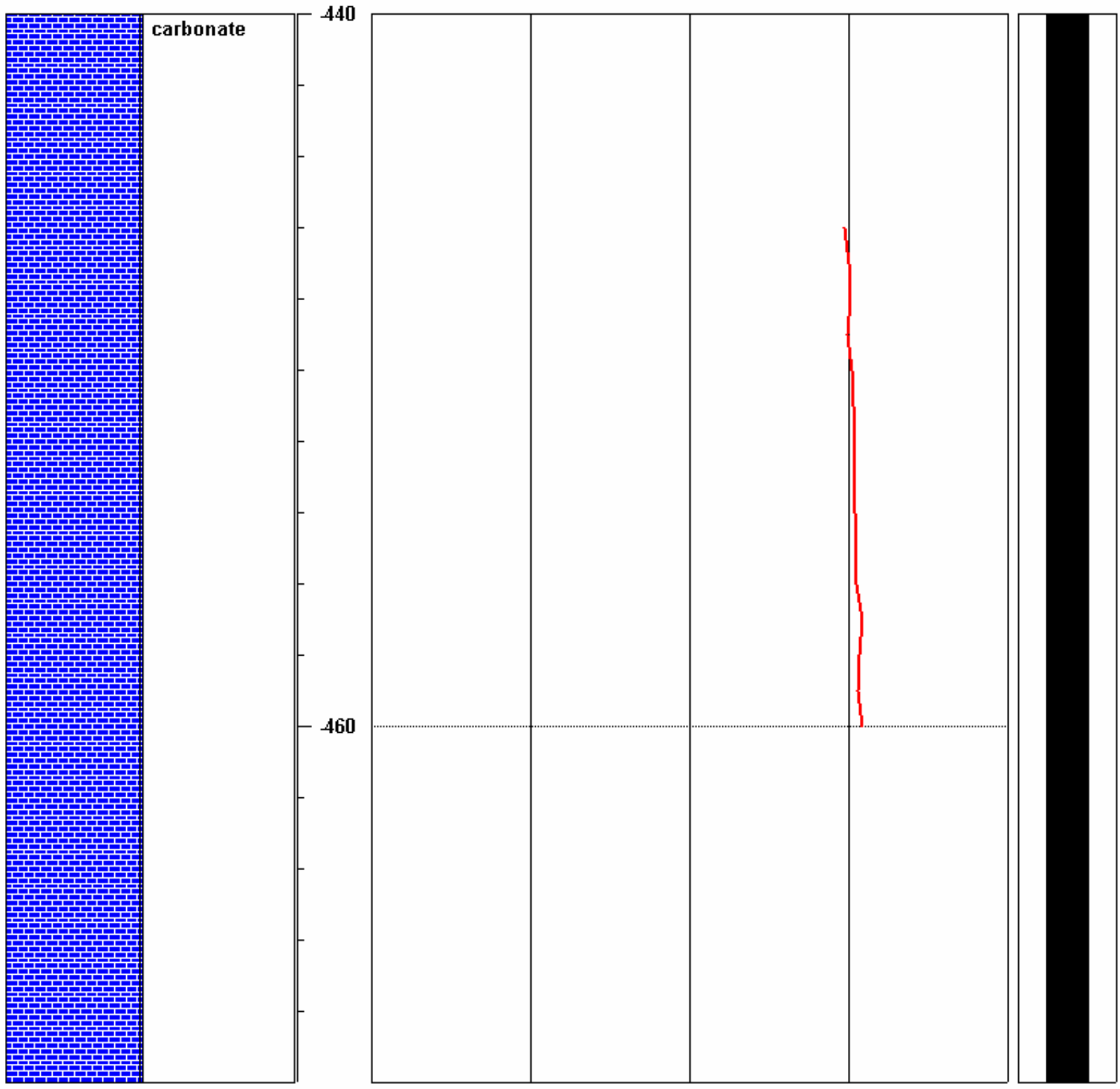

Figure 20. Temperature profile, lithology, and well construction for borehole UE-2ce. 

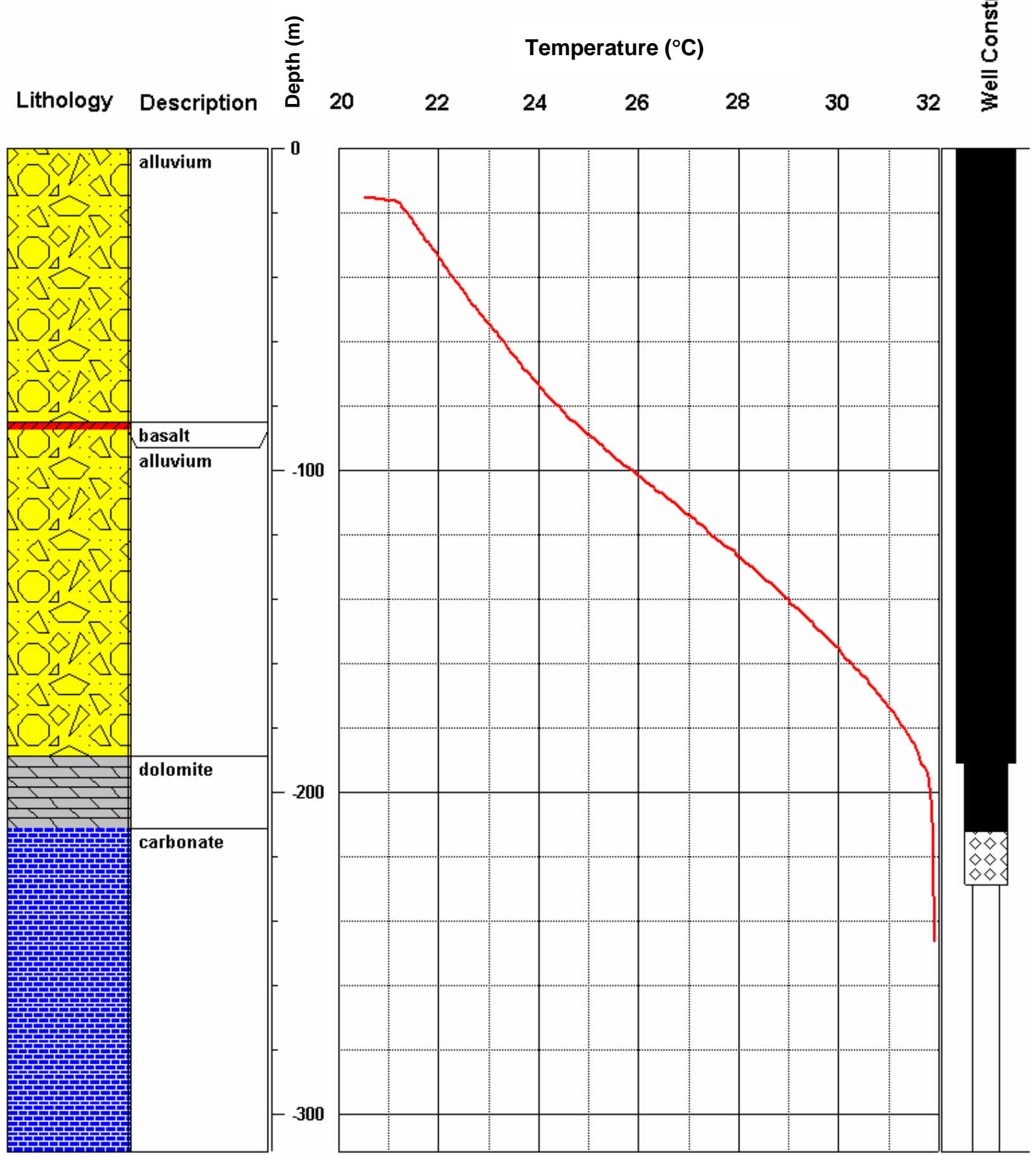

Figure 21. Temperature profile, lithology, and well construction for borehole Amargosa Test Hole \#1. 
The temperature profile for ATH1 was conducted by DRI on February 15, 2003, using DRI's PHASe temperature probe. As seen in Figure 21, a slight change in temperature gradient occurs at the basalt unit located within the alluvium. A pronounced change in gradient can be seen at the contact between the alluvium and the dolomite/carbonate lithologies. The average thermal gradient above the contact between the alluvium and dolomite/carbonate lithologies penetrated by the borehole yields a geothermal gradient of $0.0606{ }^{\circ} \mathrm{C} \mathrm{m}^{-1}$. Using a thicknessweighted harmonic mean thermal conductivity of $1.21 \mathrm{~W} \mathrm{~m}^{-1}{ }^{\circ} \mathrm{C}^{-1}$ for the alluvium (Gillespie et al., 1995) and the basalt units (Sass et al., 1987) combined with the measured thermal gradient results in a heat flow value of $73.3 \mathrm{~mW} \mathrm{~m}^{-2}$. Within the carbonate units, the thermal gradient is $0.001{ }^{\circ} \mathrm{C} \mathrm{m}^{-1}$. Using a thermal conductivity of $5.0 \mathrm{~W} \mathrm{~m}^{-1}{ }^{\circ} \mathrm{C}^{-1}$ for the carbonate units results in a calculated heat flow value of $5.0 \mathrm{~mW} \mathrm{~m}^{-2}$.

ATH2 (Figure 22) was completed on August 11, 1966, to a depth of $252.4 \mathrm{~m}$ below ground surface. Casing, $19.4 \mathrm{~cm}$ in diameter, was cemented in the borehole to a depth of $236.2 \mathrm{~m}$ below ground surface. The bottom $11.3 \mathrm{~m}$ of this casing was perforated. Depth to static water level in the well is $12 \mathrm{~m}$ below ground surface, resulting in approximately $212.9 \mathrm{~m}$ of fluid above the top of the perforated casing in the borehole.

The temperature profile for ATH2 was obtained by DRI on February 15, 2003, using DRI's PHASe temperature probe. As seen in Figure 22, a slight change in temperature gradient occurs at the top of the basalt unit located within the alluvium. A pronounced change in gradient can be seen at the contact between the alluvium and the dolomite lithologies. The average thermal gradient above the contact between the alluvium and dolomite lithologies penetrated by the borehole yields a geothermal gradient of $0.0579{ }^{\circ} \mathrm{C} \mathrm{m}^{-1}$. Using a thickness-weighted harmonic mean thermal conductivity of $1.25 \mathrm{~W} \mathrm{~m}^{-1}{ }^{\circ} \mathrm{C}^{-1}$ for the alluvium (Gillespie et al., 1994) and the basalt unit (Sass et al., 1987) combined with the measured thermal gradient results in a heat flow value of $72.4 \mathrm{~mW} \mathrm{~m}^{-2}$. Within the carbonate units, the thermal gradient is vertical or reversed. A reversed gradient (decrease in temperature with depth) would appear to indicate the presence of downward heat flow, however, a more likely explanation would be an actual cooling (the advective removal of heat) of the carbonate units due to considerable lateral flow from a zone of cooler fluids possibly higher in the stratigraphic section.

Additionally, both ATH1 and ATH2 temperature profiles display significant convex upward curvatures of the temperature profiles within the alluvium interval between the carbonate and basalt lithologies penetrated by the boreholes. These curvatures may be indicative of upward flow within the alluvium between the carbonate aquifer and basalt units in this area. Within the alluvium intervals of both boreholes, the upper intervals of alluvium display smaller gradients than the lower intervals. Assuming the thermal conductivities of the upper and lower alluvium intervals are the same would suggest a reduction in heat flow in the upper alluvium intervals compared to the lower alluvium intervals. A possible explanation for this reduction in heat flow would be the removal of heat energy through advection by horizontal fracture flow within the basalt units. However, the change in gradient between the upper and lower alluvial units may be due to differences in thermal conductivity resulting from differences in sediment composition (i.e., carbonate-fragment-dominated-alluvium versus tuff-fragment-dominated alluvium). The concave downward profiles in the lower alluvium at ATH\#1 and \#2 could also be attributed to greater compaction (thus, higher thermal conductivity) deeper in the profiles. 

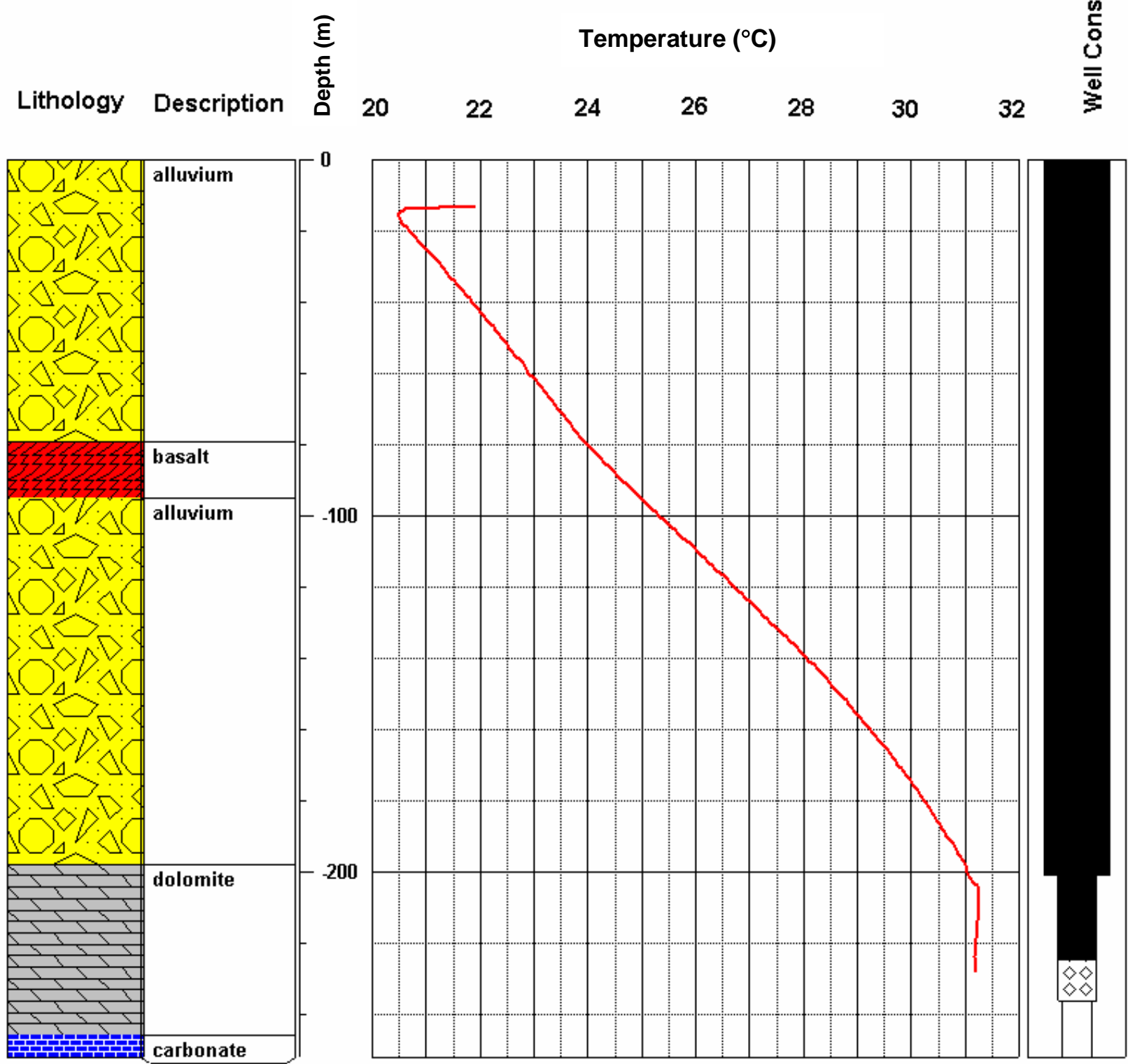

Figure 22. Temperature profile, lithology, and well construction for borehole Amargosa Test Hole \#2.

\section{UE-18t}

UE-18t (Figure 23) was completed on October 6, 1978, to a depth of $792.5 \mathrm{~m}$ below ground surface. Several casing and liner strings were placed in the hole at various depths, however, a final tubing string, $7.3 \mathrm{~cm}$ in diameter, was placed in the borehole to a depth of $577.9 \mathrm{~m}$ below ground surface and cemented to the surface. Depth to static water level in the well is approximately $279 \mathrm{~m}$ below ground surface, resulting in approximately $299 \mathrm{~m}$ of fluid above the bottom of the casing in the borehole. The saturated portion of the borehole above the bottom of the casing is located within interbedded units of volcanic tuff of various thickness. 


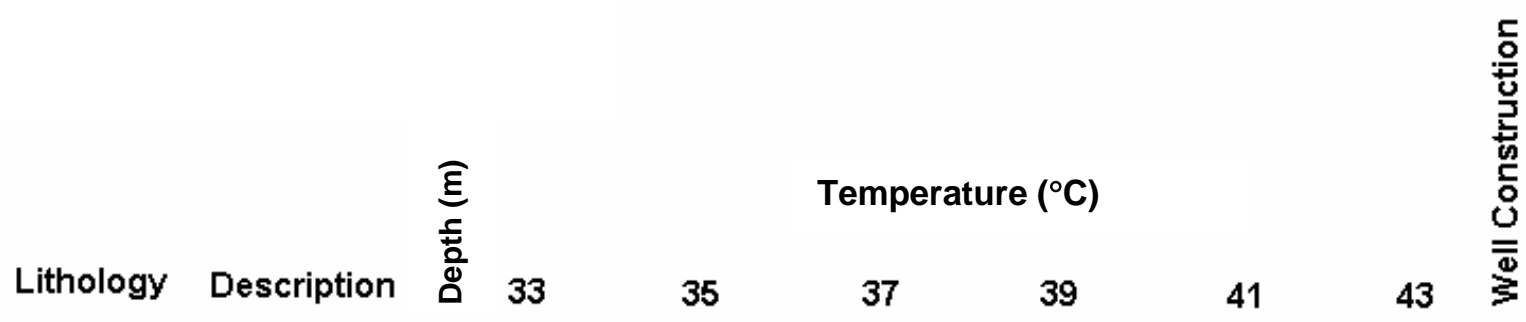

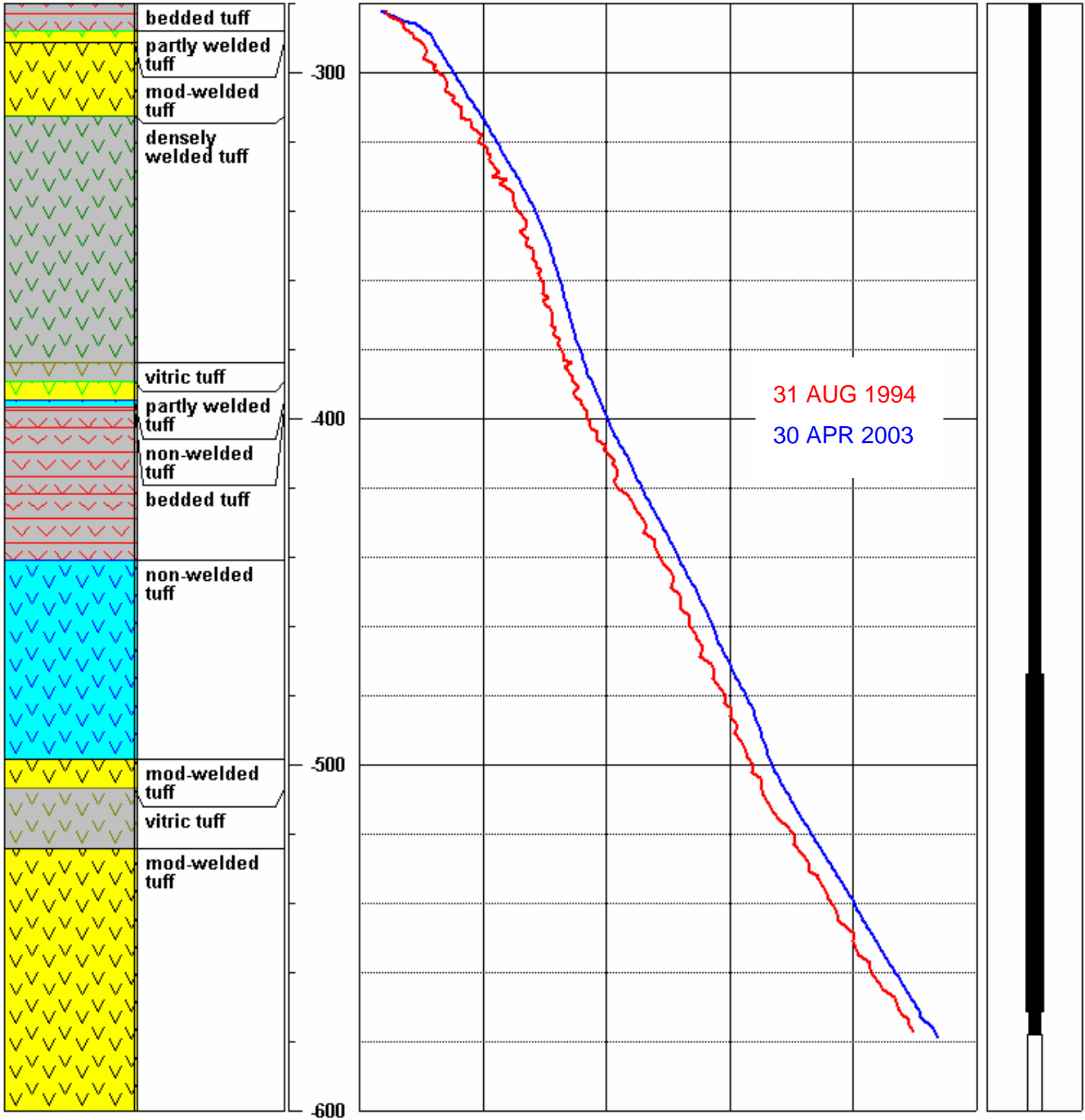

Figure 23. Comparison of UE-18t temperature profiles obtained by LLNL on August 31, 1994, and by DRI on April 30, 2003. 
DRI conducted the temperature profile from UE-18t on August 31, 1994, using the previously described thermistor inside a stainless-steel housing temperature probe. The harmonic mean of the thermal conductivities (Sass et al., 1987) of the volcanic units encountered by the borehole between the static water level in the borehole and the bottom of the casing located at $577.9 \mathrm{~m}$ below ground surface was calculated to yield a composite thermal conductivity of $1.71 \mathrm{~W} \mathrm{~m}^{-1}{ }^{\circ} \mathrm{C}^{-1}$. The average geothermal gradient over this interval is $0.0271^{\circ} \mathrm{C} \mathrm{m}^{-1}$, resulting in a heat flow value of $46.3 \mathrm{~mW} \mathrm{~m}^{-2}$.

On April 30, 2003, DRI obtained a temperature profile from borehole UE-18t using DRI's PHASe temperature probe. Changes in temperature gradient with depth appear to roughly correspond to changes in welding of the tuff units penetrated by the borehole. Using this profile, the average geothermal gradient over the identical interval is $0.0279{ }^{\circ} \mathrm{C} \mathrm{m}^{-1}$, resulting in a heat flow value of $47.7 \mathrm{~mW} \mathrm{~m}^{-2}$.

A cross plot of temperature data from the earlier and later temperature profiles from borehole UE-18t yields a correlation coefficient of 0.999 with a slope of 1.016 . The correlation coefficient is excellent; the difference in slope indicates a small error in temperature measurement in the earlier temperature profile, resulting in a slight error in the calculated heat flow.

\section{ER-3-1 string \#2}

ER-3-1 (Figure 24) was completed on May 4, 1994, to a total depth of $853 \mathrm{~m}$. Two 7.3-cm-diameter tubing strings were cemented in place within the borehole. The deeper tubing string (\#1) has a Moyno ${ }^{\circledR}$ pump installed within the tubing and could not be logged. The shallower tubing string (\#2) contains an interval of slotted tubing extending from 688.8 to $698 \mathrm{~m}$ below ground surface. The annular space between both slotted intervals and the borehole was filled with gravel pack. A Moyno® stator is located at $665.3 \mathrm{~m}$ below ground surface within the shallower tubing string, preventing logging below that depth. Depth to static water level in the well is approximately $614 \mathrm{~m}$ below ground surface, resulting in approximately $51 \mathrm{~m}$ of fluid above the Moyno ${ }^{\circledR}$ stator in the borehole. The saturated portion of the borehole above the Moyno® stator is located within shale and carbonate Paleozoic units.

On April 17, 2003, DRI obtained a temperature profile from the shallow tubing string at ER-3-1 using DRI's PHASe temperature probe. Using least-squares regression over the upper linear portion of the logged interval yielded a geothermal gradient of $0.03835^{\circ} \mathrm{C} \mathrm{m}^{-1}$, and combined with a thermal conductivity of $1.5 \mathrm{~W} \mathrm{~m}^{-1}{ }^{\circ} \mathrm{C}^{-1}$ (Johnston et al., 1981) for the shale penetrated by the borehole results in a heat flow value of $57.4 \mathrm{~mW} \mathrm{~m}^{-2}$.

It is of interest to note the apparent reduction in gradient across the contact between the shale and carbonate lithologies at the bottom of the temperature profile. This reduction in gradient would be expected due to the probable greater thermal conductivity (approximately $5.0 \mathrm{~W} \mathrm{~m}^{-1}{ }^{\circ} \mathrm{C}^{-1}$ ) of the carbonate unit. 


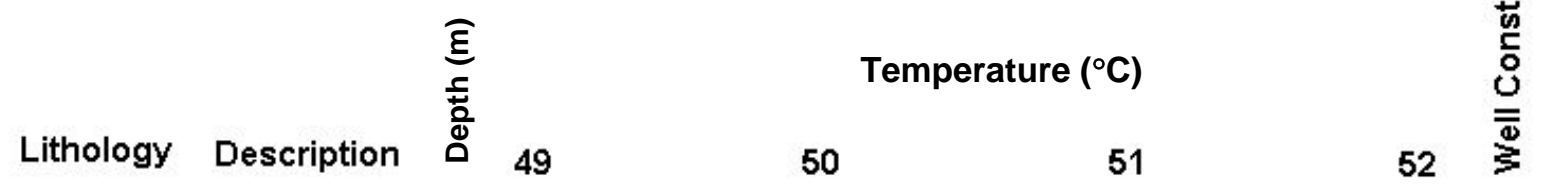

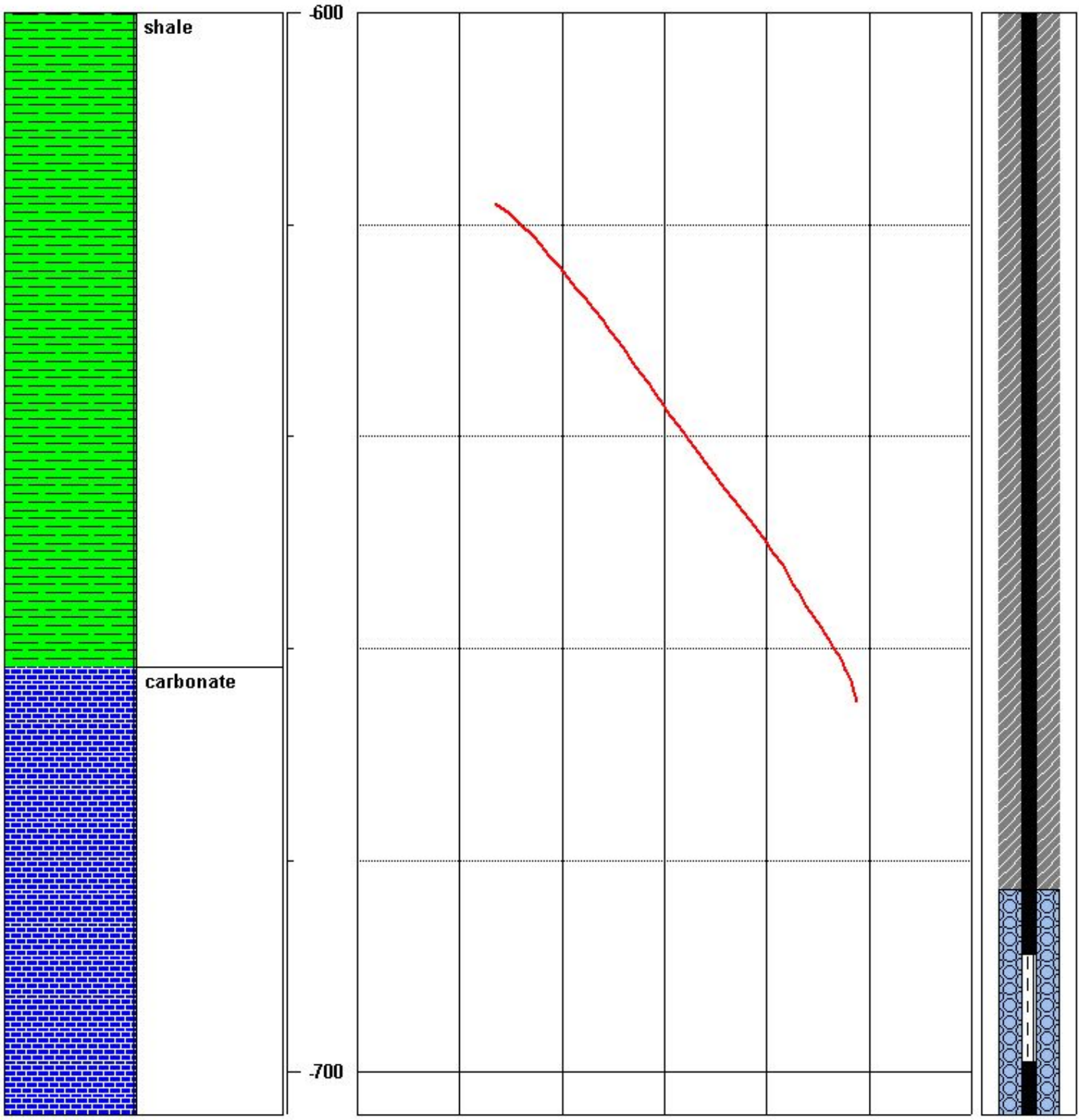

Figure 24. Temperature profile, lithology, and well construction for borehole ER-3-1 string \#2. 


\section{ER-3-2 string \#2}

ER-3-2 (Figure 25) was completed on December 15, 1993, to a total depth of $914.4 \mathrm{~m}$. Two 7.3-cm-diameter tubing strings and one 4.8-cm-diameter tubing string were cemented in place within the borehole. The deeper tubing string (\#1) has a Moyno® pump installed within the tubing and could not be logged. The middle tubing string (\#2) contains an interval of slotted tubing extending from 796.9 to 803 m below ground surface. A Moyno® stator is located at 774 $\mathrm{m}$ below ground surface within the middle tubing string, preventing logging below that depth. The shallow 4.8-cm-diameter tubing string (\#3) extends into the wellbore only to $542.3 \mathrm{~m}$ below ground surface, just below the static water level within the borehole. Depth to static water level in the well is approximately $490 \mathrm{~m}$ below ground surface, resulting in approximately $284 \mathrm{~m}$ of fluid above the Moyno ${ }^{\circledR}$ stator within tubing string \#2. The saturated portion of the borehole above the Moyno ${ }^{\circledR}$ stator is located entirely within alluvium.

On April 17, 2003, DRI obtained a temperature profile from the middle tubing string (\#2) at ER-3-2 using DRI's PHASe temperature probe. Using a least-squares linear regression over the logged interval of this profile yielded a geothermal gradient of $0.0170{ }^{\circ} \mathrm{C} \mathrm{m}^{-1}$. Combined with a thermal conductivity of $1.2 \mathrm{~W} \mathrm{~m}^{-1}{ }^{\circ} \mathrm{C}^{-1}$ for the alluvium (Gillespie et al., 1994) results in a heat flow value of $20.4 \mathrm{~mW} \mathrm{~m}^{-2}$.

\section{UE-3e\#4}

UE-3e\#4 (Figure 26) was completed on March 29, 1990, to a total depth of $701 \mathrm{~m}$. Three 7.3-cm-diameter tubing strings were cemented in place within the borehole. The deeper tubing string (\#1) contains an interval of slotted tubing extending from 655.3 to $661.7 \mathrm{~m}$ below ground surface. Depth to static water level in the well is approximately $366 \mathrm{~m}$ below ground surface, resulting in approximately $377.7 \mathrm{~m}$ of fluid above the slotted interval within tubing string \#1. The saturated portion of the borehole above the slotted interval of tubing string \#1 is located within volcanic tuffs.

On May 13, 2003, DRI obtained a temperature profile from the deeper tubing string in UE-3e\#4 using DRI's PHASe temperature probe. The average geothermal gradient over the logged interval above the top of the slotted tubing in the deeper tubing string was determined to be $0.0118{ }^{\circ} \mathrm{C} \mathrm{m}^{-1}$. The harmonic mean of the thermal conductivity of the volcanic units over the logged interval of $1.562 \mathrm{~W} \mathrm{~m}^{-1}{ }^{\circ} \mathrm{C}^{-1}$ (Sass et al., 1987) combined with the geothermal gradient determined from the temperature profile yields a heat flow value of $18.4 \mathrm{~mW} \mathrm{~m}^{-2}$.

\section{UE-4t string \#1}

UE-4t (Figure 27) was originally completed on January 5, 1987, to a total depth of 735.5 m. In March 1992, UE-4t was recompleted with the placement of two 7.3-cm-diameter tubing strings cemented in place within the borehole. The deeper tubing string (\#1) contains an interval of slotted tubing extending from 598.3 to $607.2 \mathrm{~m}$ below ground surface. Depth to static water level in the deeper tubing string is $147.2 \mathrm{~m}$ below ground surface, resulting in approximately $451 \mathrm{~m}$ of fluid above the slotted tubing in string \#1. The saturated portion of the borehole above the slotted interval penetrates units of volcanic tuff. The volcanic units in which the deeper tubing string at UE-4t is completed contain elevated head as a result of underground testing in the area surrounding UE-4t. Therefore, although the static water level was measured at approximately $150 \mathrm{~m}$ below ground surface, only the portion of the temperature profile below $300 \mathrm{~m}(1,000 \mathrm{ft})$ was used for the calculation of heat flow. 


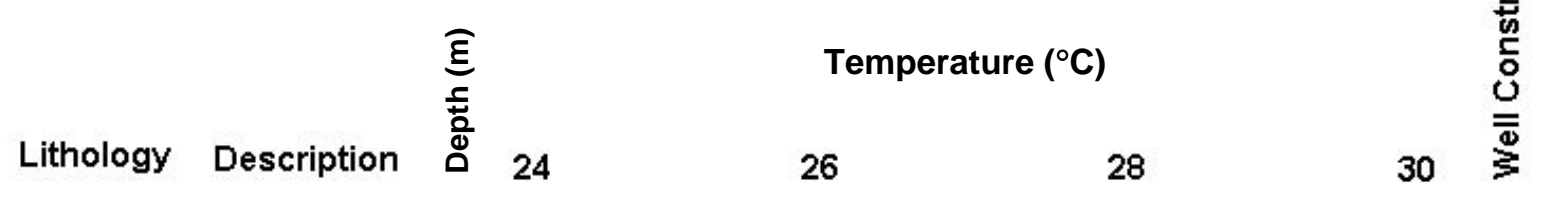

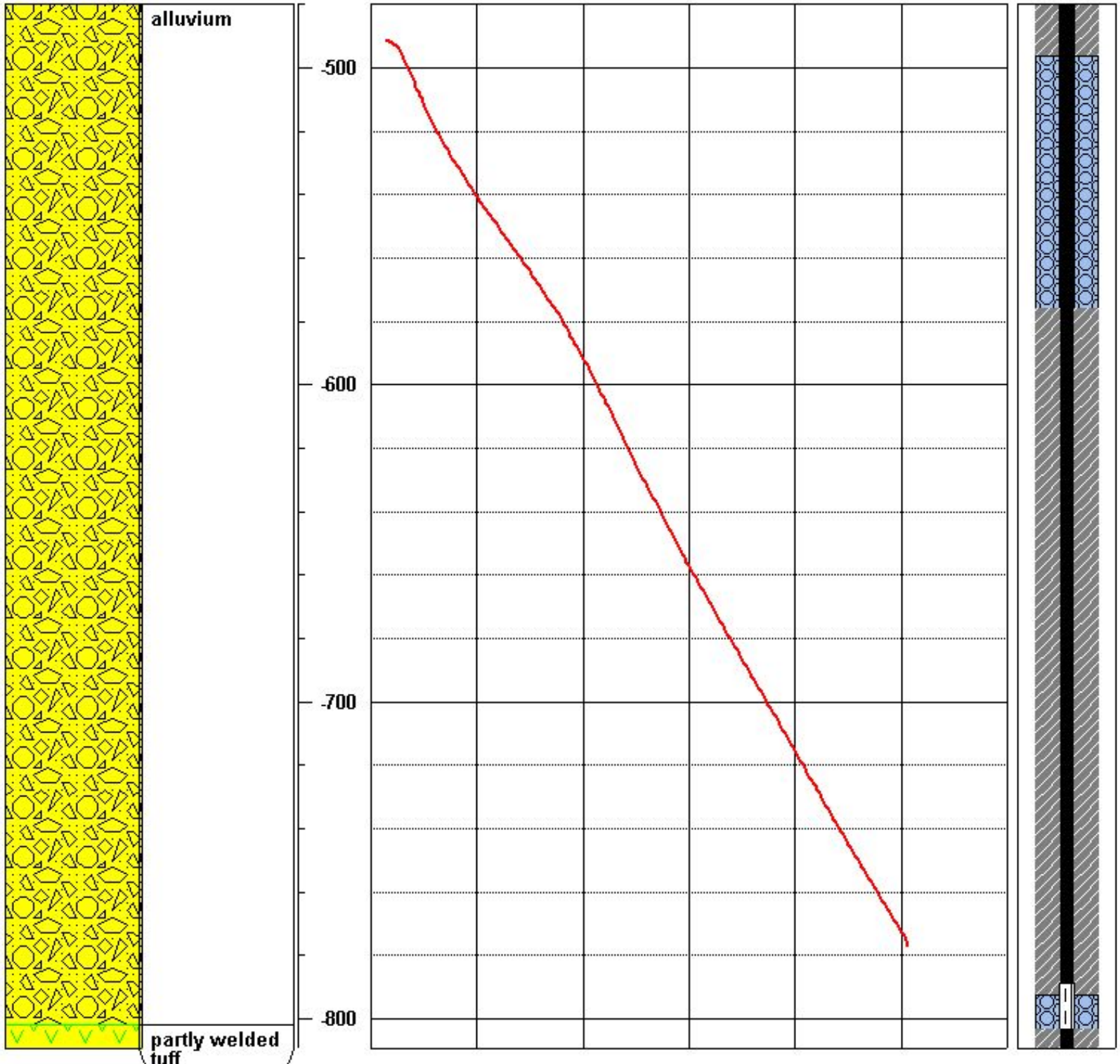

Figure 25. Temperature profile, lithology, and well construction for borehole ER-3-2 string \#2. 


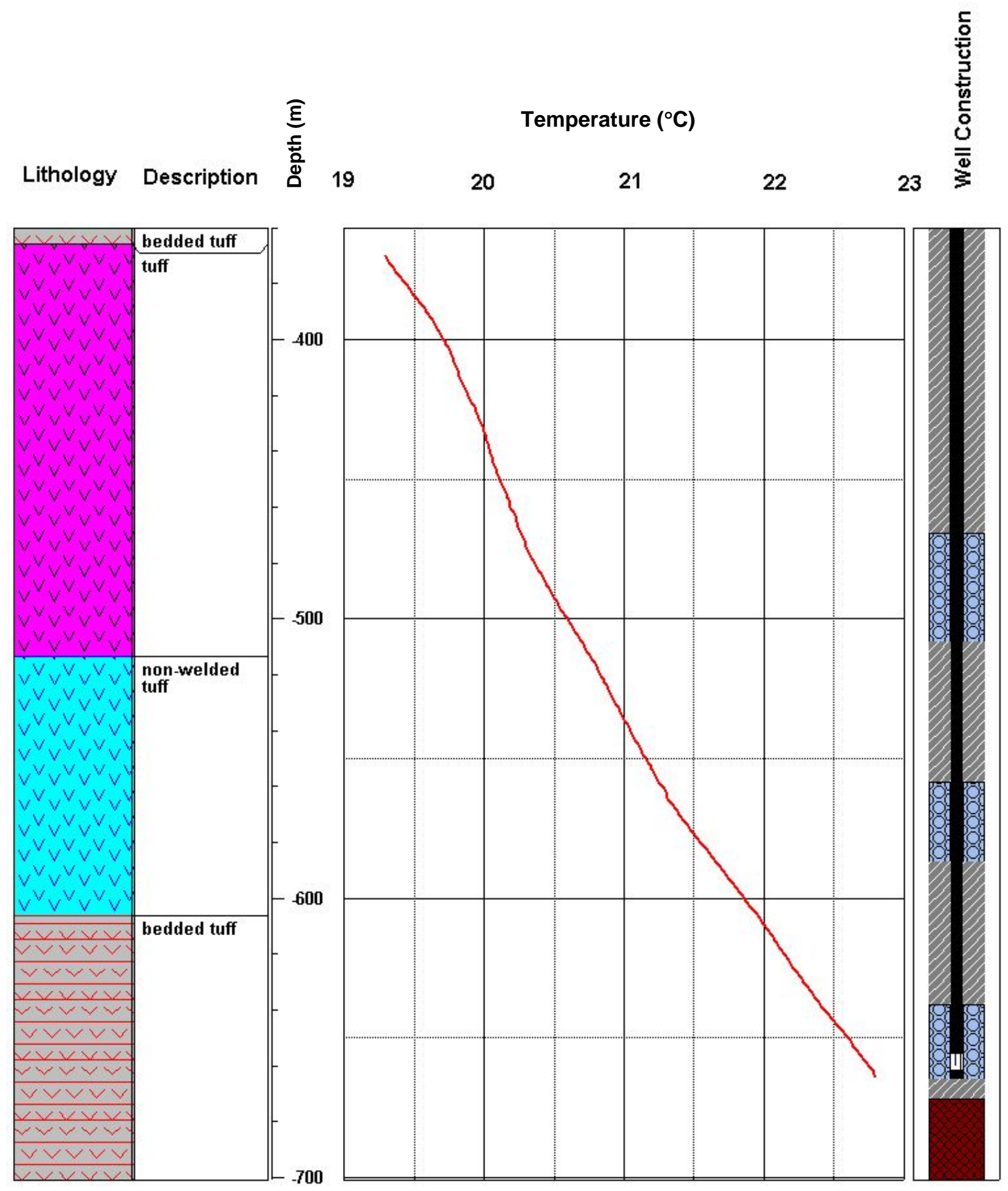

Figure 26. Temperature profile, lithology, and well construction for borehole UE-3e\#4 string \#1. 


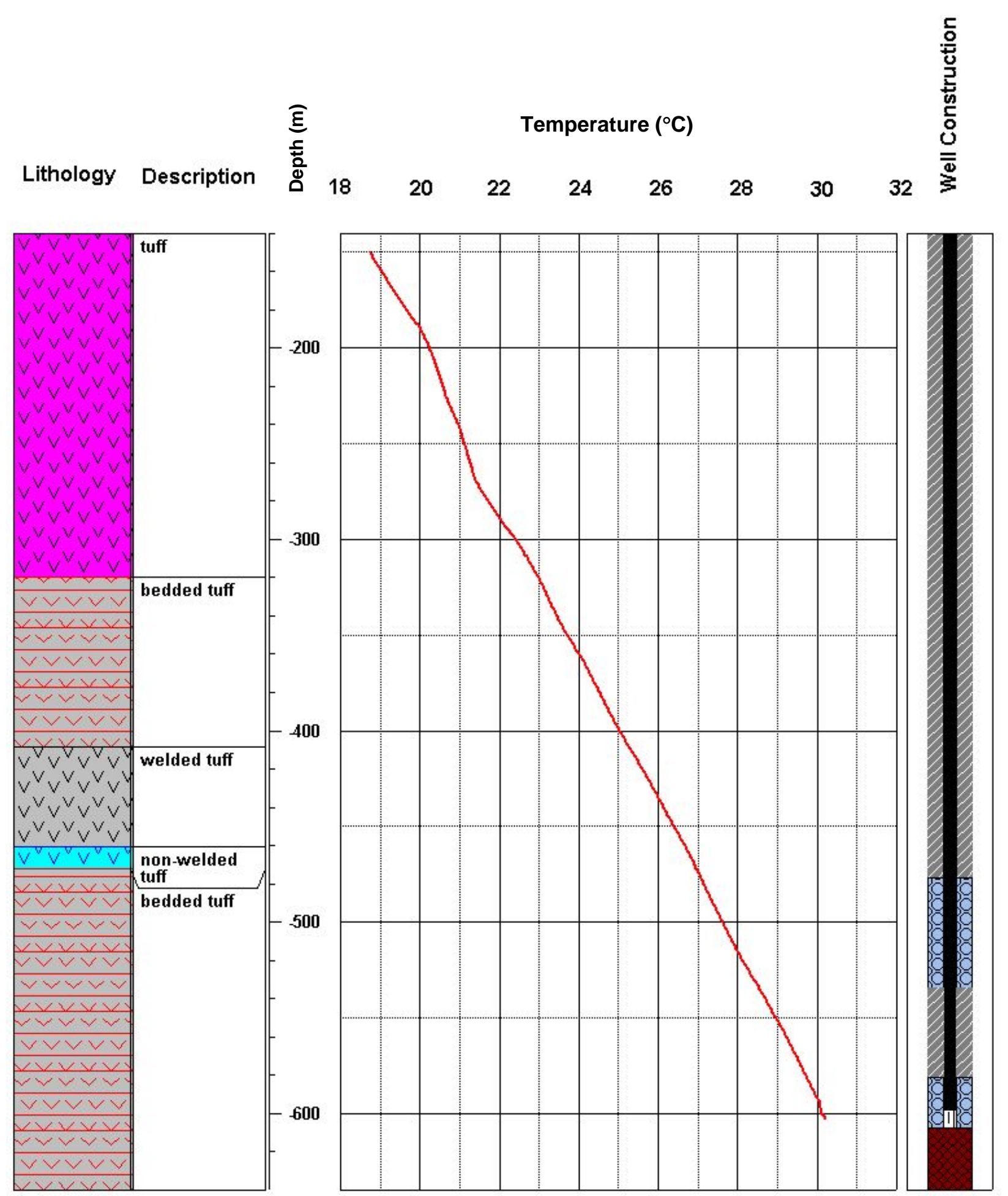

Figure 27. Temperature profile, lithology, and well construction for borehole UE-4t string \#1. 
On May 13, 2003, DRI obtained a temperature profile from the deep tubing string (\#1) at UE-4t using DRI's PHASe temperature probe. Using this profile, the average geothermal gradient over the logged interval from the top of the bedded tuff to the top of the slotted tubing is $0.0258{ }^{\circ} \mathrm{C} \mathrm{m}^{-1}$, and combined with a harmonic mean of $1.74 \mathrm{~W} \mathrm{~m}^{-1}{ }^{\circ} \mathrm{C}^{-1}$ (Sass et al., 1987) for the volcanic tuff units penetrated by the borehole results in a heat flow value of $44.9 \mathrm{~mW} \mathrm{~m}^{-2}$. UE-4t is located on the southern boundary of the subsidence crater formed by the U-4t underground nuclear test. The somewhat elevated heat flow, as well as the unusual change in gradient in the temperature profile observed at approximately $270 \mathrm{~m}$ below ground surface, may indicate that the temperature profile from UE-4t has been affected by the heat produced by the underground test conducted at U-4t.

\section{ER-19-1}

ER-19-1 (Figure 28) was completed on June 18, 1993, to a total depth of 1,095.8 m below ground surface. Three tubing strings were cemented in place within the borehole. The deepest tubing string (\#1) is $13.97 \mathrm{~cm}$ in diameter and contains two intervals of slotted tubing extending from 1,051.7 to 1,069.9 $\mathrm{m}$ and from 990.3 to 1,008.5 m below ground surface. Depth to static water level in tubing string \#1 is approximately $544 \mathrm{~m}$ below ground surface, resulting in approximately $446 \mathrm{~m}$ of fluid above the slotted interval within tubing string \#1. The saturated portion of the borehole above the slotted interval of tubing string \#1 penetrates various volcanic tuffs units.

On April 22, 2003, DRI obtained a temperature profile from the deeper tubing string in ER-19-1 using DRI's PHASe temperature probe. Changes in temperature gradient with depth appear to roughly correspond to changes in lithology of the units penetrated by the borehole. The average geothermal gradient over the logged interval above the top of the slotted tubing in the deeper tubing string was determined to be $0.017^{\circ} \mathrm{C} \mathrm{m}^{-1}$. The harmonic mean of the thermal conductivity of the volcanic units over the logged interval of $1.82 \mathrm{~W} \mathrm{~m}^{-1}{ }^{\circ} \mathrm{C}^{-1}$ (Sass et al., 1987) combined with the geothermal gradient determined from the temperature profile yields a heat flow value of $30.9 \mathrm{~mW} \mathrm{~m}^{-2}$.

\section{ER-5-3\#2}

ER-5-3\#2 (Figure 29) was completed in May 2000 to a total depth of 1,095.8 m below ground surface. The borehole was recompleted in March 2001, with 13.97-cm-diameter casing cemented in place within the borehole. The 13.97-cm-diameter casing contains intervals of slotted tubing extending from 451 to $529.4 \mathrm{~m}$ and 737.7 to $776.9 \mathrm{~m}$ below ground surface. Adjacent to the casing, a string of 7.3-cm-diameter tubing was placed to a depth of $673.9 \mathrm{~m}$. This tubing contains a slotted interval from 637 to $667.4 \mathrm{~m}$ below ground surface. Depth to static water level in the well is approximately $293 \mathrm{~m}$ below ground surface, resulting in approximately $344 \mathrm{~m}$ of fluid above the tubing slotted interval. Following hydrologic testing, a bridge plug was placed within the casing, effectively isolating the two casing slotted intervals. The saturated portion of the borehole above the slotted interval of tubing penetrates primarily alluvium sediments.

On April 22, 2003, DRI obtained a temperature profile from the tubing string adjacent to the casing in ER-5-3\#2 using DRI's PHASe temperature probe. The average geothermal gradient over the logged interval above the slotted tubing in the deeper tubing string was determined to be $0.0082{ }^{\circ} \mathrm{C} \mathrm{m}^{-1}$. The harmonic mean of the thermal conductivity of the volcanic and alluvial units 
over the logged interval of $1.2 \mathrm{~W} \mathrm{~m}^{-1}{ }^{\circ} \mathrm{C}^{-1}$ (Sass et al., 1987) combined with the geothermal gradient determined from the temperature profile yields a heat flow value of $9.8 \mathrm{~mW} \mathrm{~m}$.

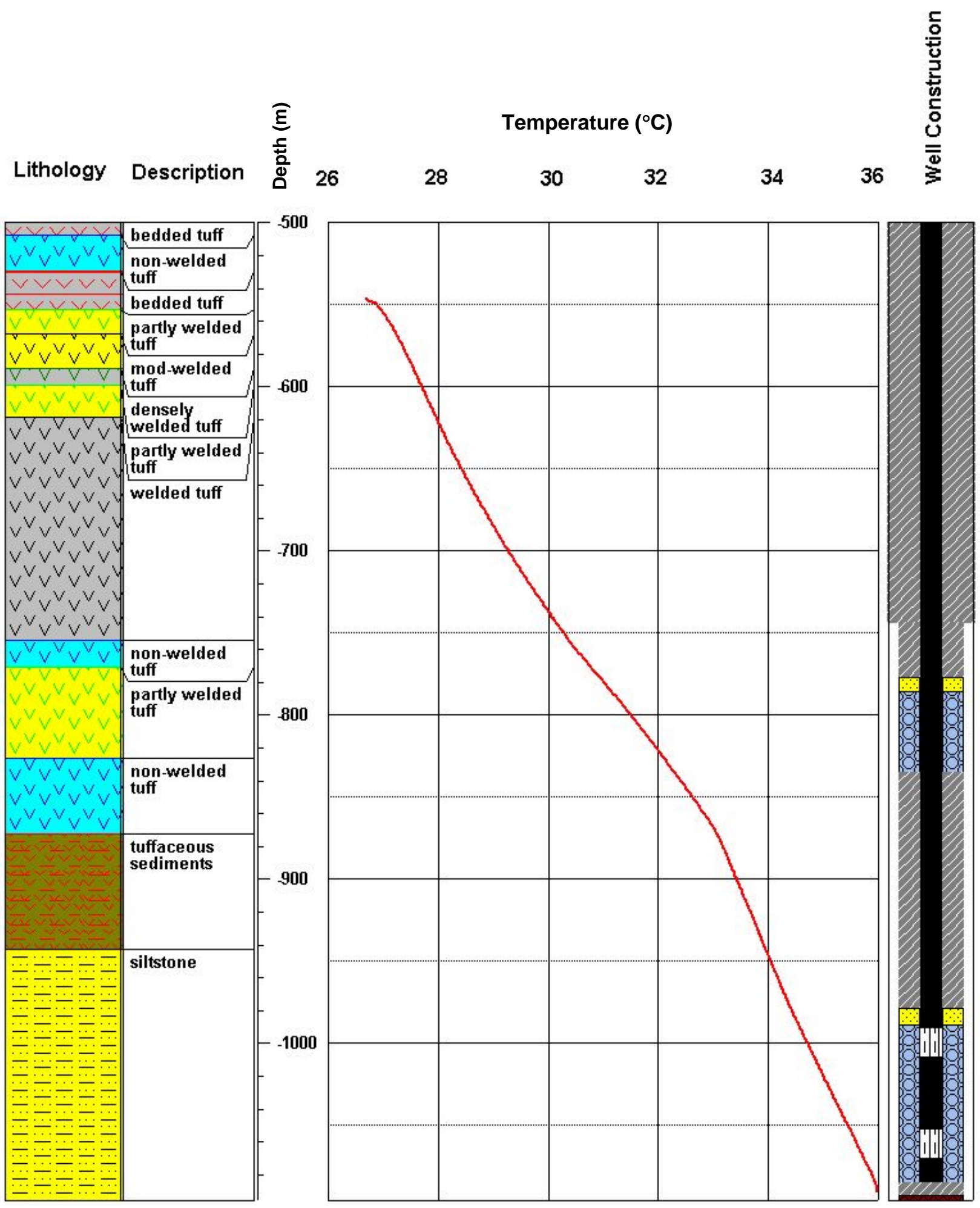

Figure 28. Temperature profile, lithology, and well construction for borehole ER-19-1 string \#1. 

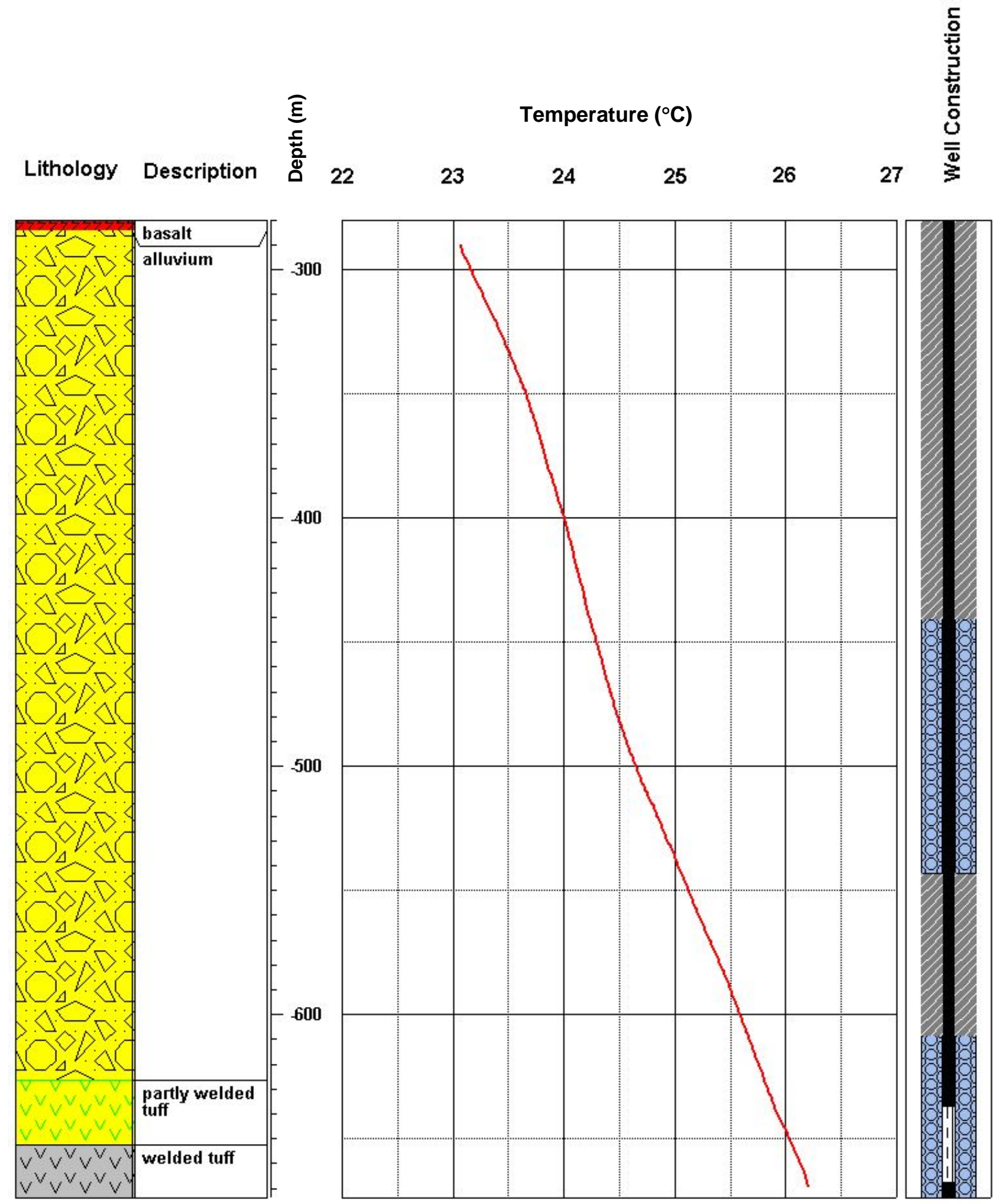

Figure 29. Temperature profile, lithology, and well construction for borehole ER-5-3 string \#2. 
Obvious breaks in the geothermal gradient are evident at $345 \mathrm{~m}$ and $480 \mathrm{~m}$ below ground surface. Although the lithologic log for ER-5-3\#2 describes this interval as undifferentiated alluvium, variations in sediment characteristics (different depositional intervals) may produce changes in lithology and thus gradient. Additionally, ER-5-3\#2 is located in extreme northern Frenchman Flat adjacent to normal faults present to the south of Frenchman Mountain where volcanic units are exposed at the surface. Local recharge (Laaczniak et al., 1996) may produce downward and lateral groundwater flow, resulting in the extremely low heat flow value of $9.8 \mathrm{~mW} \mathrm{~m}^{-2}$ determined at ER-5-3\#2.

\section{Water Well 2}

Water Well 2 (Figure 30) was completed in March 1962 to a total depth of 1,043 m below ground surface. The borehole was completed with 21.9-cm-diameter casing cemented in place within the borehole. Below the bottom of the casing at $781.2 \mathrm{~m}$, a 16.8 -cm-diameter perforated liner was hung to a depth of $823 \mathrm{~m}$ below ground surface. Depth to static water level in the well is approximately $626 \mathrm{~m}$ below ground surface, resulting in approximately $155 \mathrm{~m}$ of fluid above the bottom of the casing. The saturated portion of the borehole above the bottom of the casing penetrates tuffaceous sediments.

On April 17, 2003, DRI obtained a temperature profile from Water Well 2 using DRI's PHASe temperature probe. A least-squares regression over the linear portion of the temperature profile above the bottom of the casing yielded a geothermal gradient of $0.0247^{\circ} \mathrm{C} \mathrm{m}^{-1}$. Utilizing a thermal conductivity of $1.8 \mathrm{~W} \mathrm{~m}^{-1}{ }^{\circ} \mathrm{C}^{-1}$ (Johnston et al. ,1981) combined with the geothermal gradient determined from the temperature profile yields a heat flow value of $44.5 \mathrm{~mW} \mathrm{~m}^{-2}$.

In the temperature profile from Water Well 2, a dramatic change in gradient occurs at approximately $765 \mathrm{~m}$ below ground surface. This location is most likely the actual contact between the overlying tuff sediments and the Paleozoic dolomite penetrated by the borehole. Although the borehole below the casing is open and subject to possible vertical fluid movement within the borehole, the thermal gradient below the break in gradient is extremely linear $\left(\mathrm{R}^{2}=0.998\right)$, indicating a lack of vertical fluid movement. A least-squares best fit for the temperature profile through the Paleozoic unit yields a geothermal gradient of $0.0069{ }^{\circ} \mathrm{C} \mathrm{m}^{-1}$. This gradient combined with a thermal conductivity of $5.0 \mathrm{~W} \mathrm{~m}^{-1}{ }^{\circ} \mathrm{C}^{-1}$ (Sass et al., 1987) results in a heat flow value of $34.5 \mathrm{~mW} \mathrm{~m}^{-2}$. This difference in calculated heat flow between the carbonate and overlying tuffaceous sediments could be due to horizontal flow and vertical mixing within the carbonate aquifer, or more likely, error in estimation of the thermal conductivity of the tuffaceous sediments or carbonate aquifer, or both. An estimated thermal conductivity of $1.4 \mathrm{~W} \mathrm{~m}^{-1}{ }^{\circ} \mathrm{C}^{-1}$ (instead of 1.8) for the tuffaceous sediments would result in a heat flow value comparable to that determined for the carbonate unit.

\section{U-20 Water Well}

U-20 Water Well (Figure 31) was drilled to a total depth of $996.1 \mathrm{~m}$ in September 1982. The borehole was completed with 34-cm-diameter casing to a depth of $975 \mathrm{~m}$. This casing contains an interval of slotted casing from 692.2 to $925.1 \mathrm{~m}$ below ground surface. Depth to static water level in the well is approximately $620 \mathrm{~m}$ below ground surface, resulting in approximately $72 \mathrm{~m}$ of fluid above the bottom of the casing. The saturated portion of the borehole above the bottom of the casing penetrates lava and bedded tuff units. 


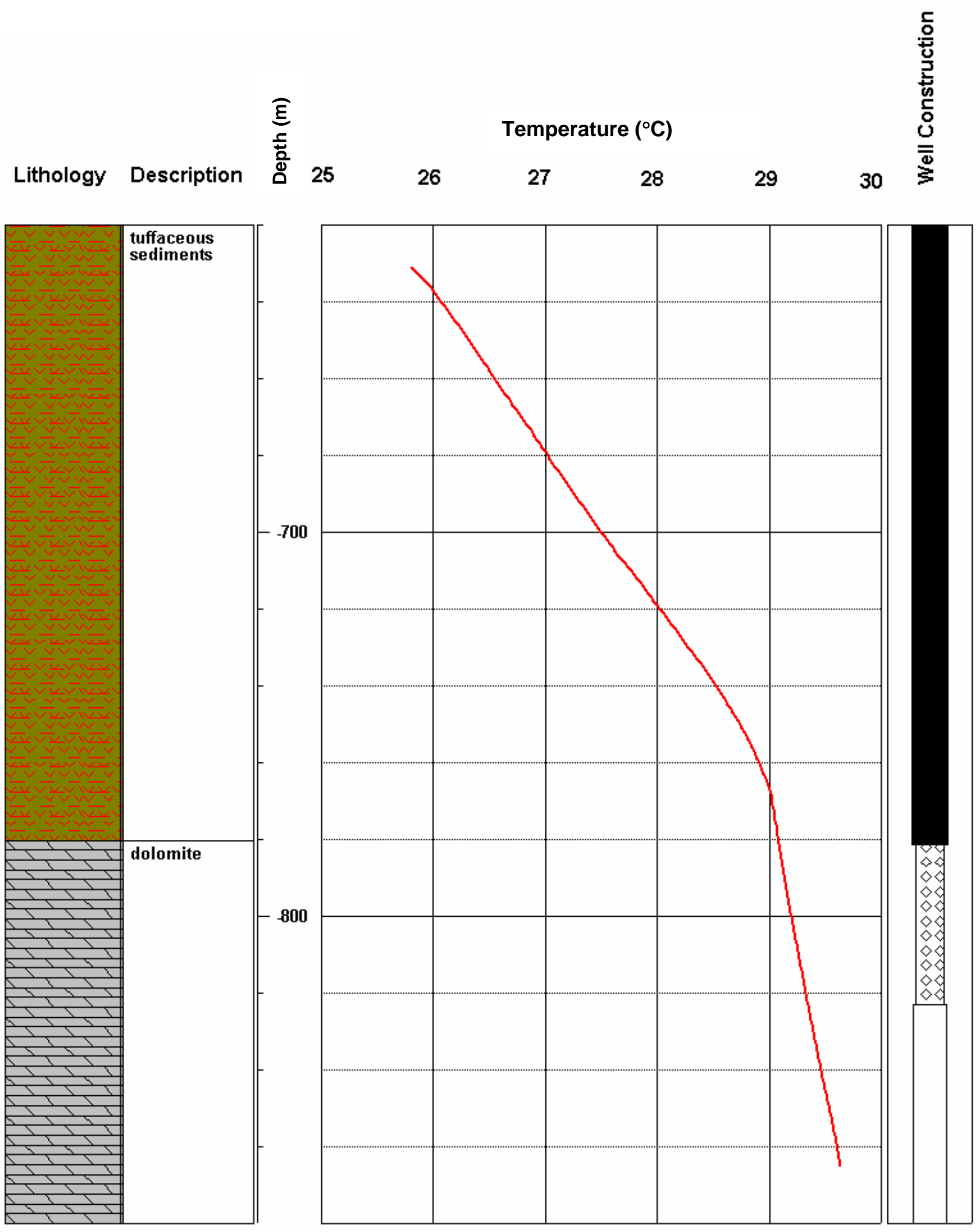

Figure 30. Temperature profile, lithology, and well construction for borehole Water Well 2. 


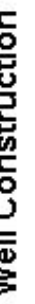

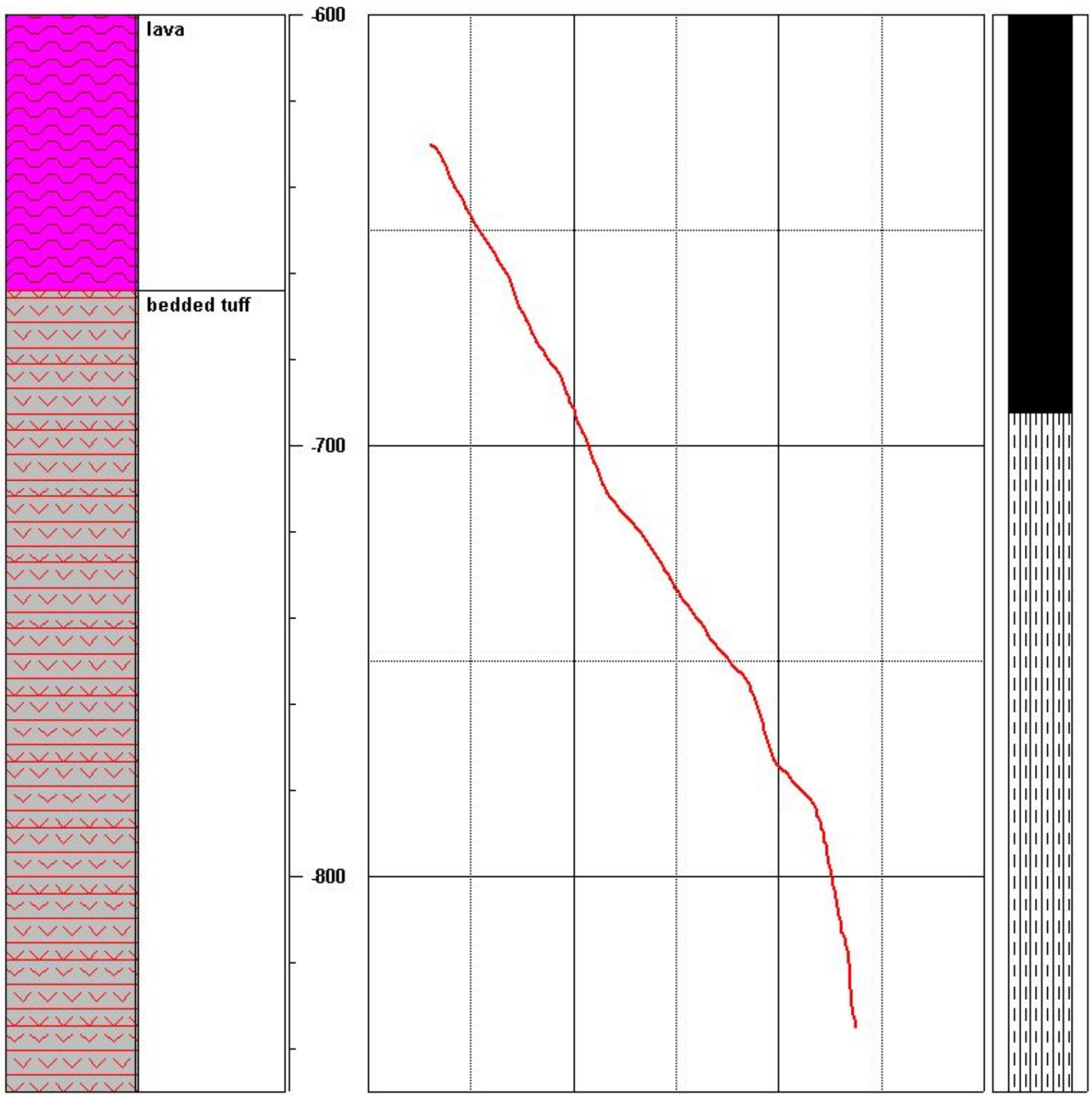

Figure 31. Temperature profile, lithology, and well construction for borehole U-20 Water Well. 
On April 30, 2003, DRI obtained a temperature profile from U-20 Water Well using DRI's PHASe temperature probe. An average of the geothermal gradient over the logged interval above the bottom of the casing was determined to be $0.0116{ }^{\circ} \mathrm{C} \mathrm{m}^{-1}$. Utilizing a thicknessweighted harmonic mean of $1.8 \mathrm{~W} \mathrm{~m}^{-1}{ }^{\circ} \mathrm{C}^{-1}$ for the lava and bedded tuff units (Sass et al., 1987) combined with the geothermal gradient determined from the temperature profile yields a heat flow value of $20.8 \mathrm{~mW} \mathrm{~m}^{-2}$.

The heat flow value of $20.8 \mathrm{~mW} \mathrm{~m}^{-2}$ for U-20 Water Well is considerably lower than would be expected for its location on Pahute Mesa at the NTS. This may be an effect of the well being used as a water supply well for many years prior to the 1992 moratorium on testing at the NTS. Fluid flow toward the borehole, with the associated mixing of the pore fluids may have lowered the apparent thermal conductivity of the units penetrated by the borehole. Or the low heat flow values could be indicative of horizontal flow, and the associated apparent lowering of heat flow values, in the lava unit penetrated by the well. Downward flow appears to be indicated within the interval of slotted casing by the concave upward and decreased thermal gradient observed in the temperature profile below $750 \mathrm{~m}$.

\section{UE-10j}

UE-10j (Figure 32) was drilled to a total depth of $725.4 \mathrm{~m}$ in May 1965. In May 1995, UE-10j was recompleted by deepening to a depth of $796.4 \mathrm{~m}$ below ground surface. The borehole was completed with a combination of 31.1-cm-diameter casing and packers to a depth of $772.4 \mathrm{~m}$. Because of the large washouts present in the borehole, packers were used to attempt to isolate various intervals of interest within the borehole. However, one interval within the well, from 704.4 to $718.4 \mathrm{~m}$ below ground surface, was cemented and may yield heat flow values representative of those in the formation outside the wellbore.

On March 4, 2003, DRI obtained a temperature profile from UE-10j using the PHASe temperature probe. A least-squares linear regression of the geothermal gradient over the cemented interval of the casing was determined to be $0.0066{ }^{\circ} \mathrm{C} \mathrm{m}^{-1}$. Using a thermal conductivity value of $5.0 \mathrm{~W} \mathrm{~m}^{-1}{ }^{\circ} \mathrm{C}^{-1}$ for the carbonate lithology (Sass et al., 1987) combined with the geothermal gradient determined from the temperature profile yields a heat flow value of $33.0 \mathrm{~mW} \mathrm{~m}^{-2}$. The intervals of near-vertical thermal gradient, especially near the bottom of the temperature profile, may indicate significant lateral groundwater flow within the Paleozoic aquifer penetrated by the borehole.

\section{ER-20-5\#1 string \#2}

ER-20-5\#1 (Figure 33) was drilled to a total depth of $860.5 \mathrm{~m}$ in November 1995. The borehole was completed with two strings of 7.3-cm-diameter tubing. Both strings of tubing contain slotted intervals located within the same gravel pack zone. The first tubing string contains a Moyno® pump and could not be temperature logged. The second string contains an interval of slotted casing from 705.6 to $723.5 \mathrm{~m}$ below ground surface. Depth to static water level in the well is approximately $626 \mathrm{~m}$ below ground surface, resulting in approximately $80 \mathrm{~m}$ of fluid above the top of the slotted tubing. The saturated portion of the borehole above the top of the slotted tubing penetrates units of bedded tuff and partly welded tuff. 


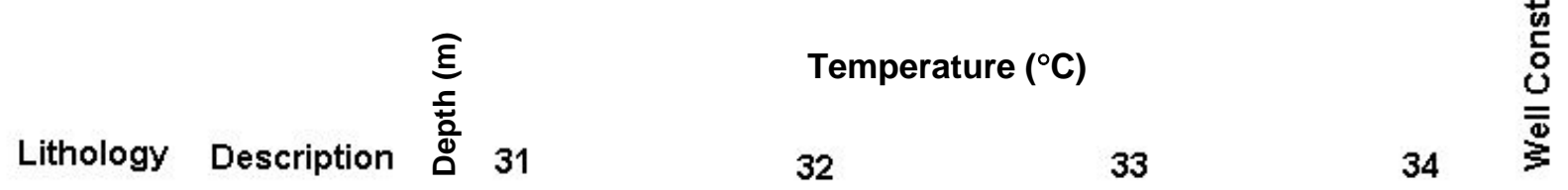

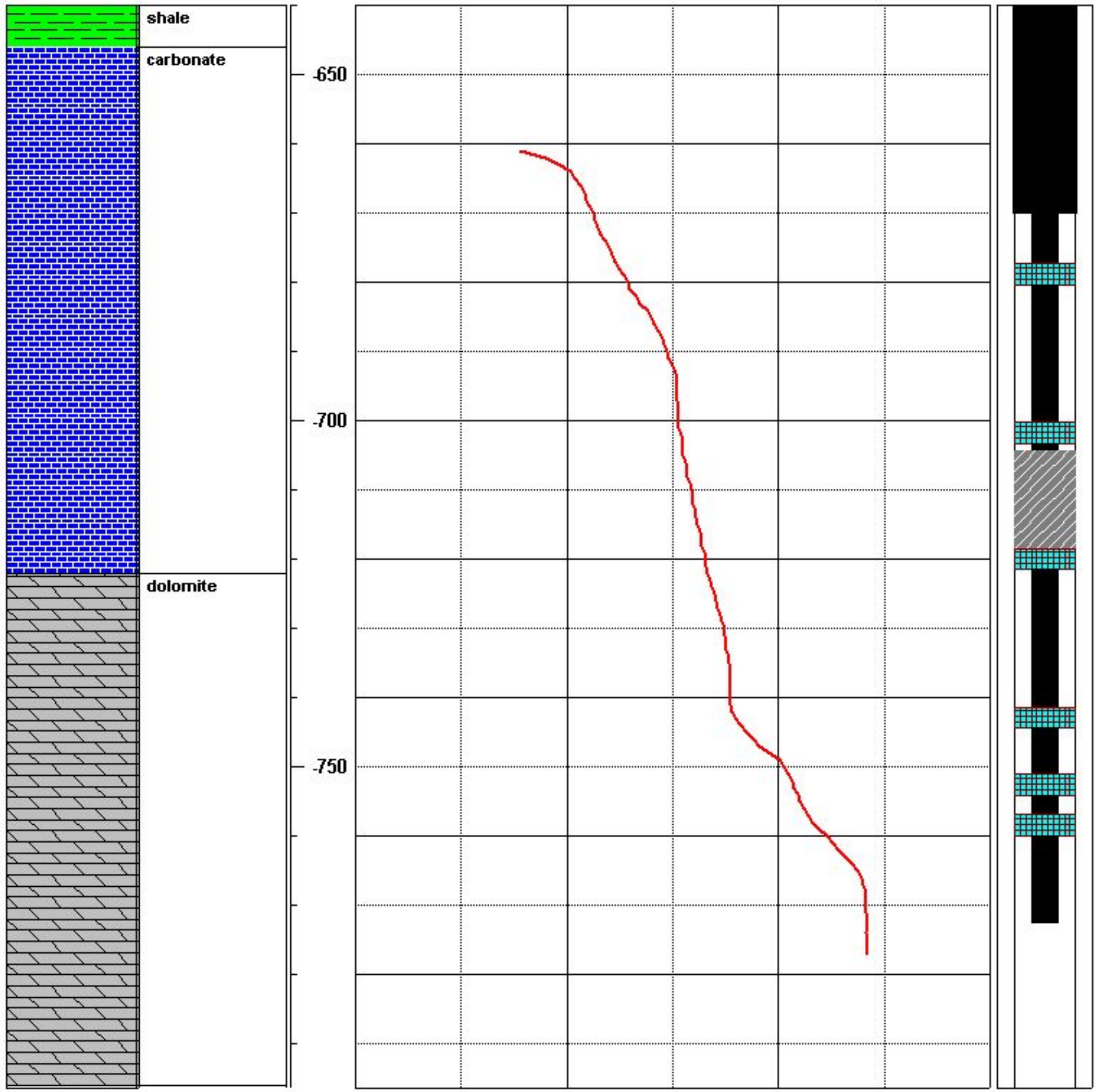

Figure 32. Temperature profile, lithology, and well construction for borehole UE-10j. 


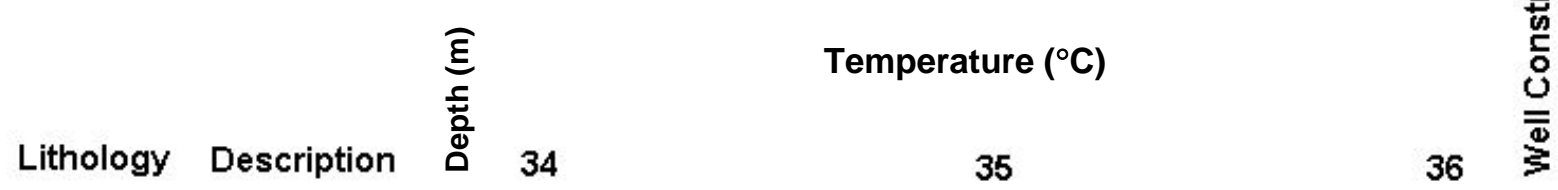

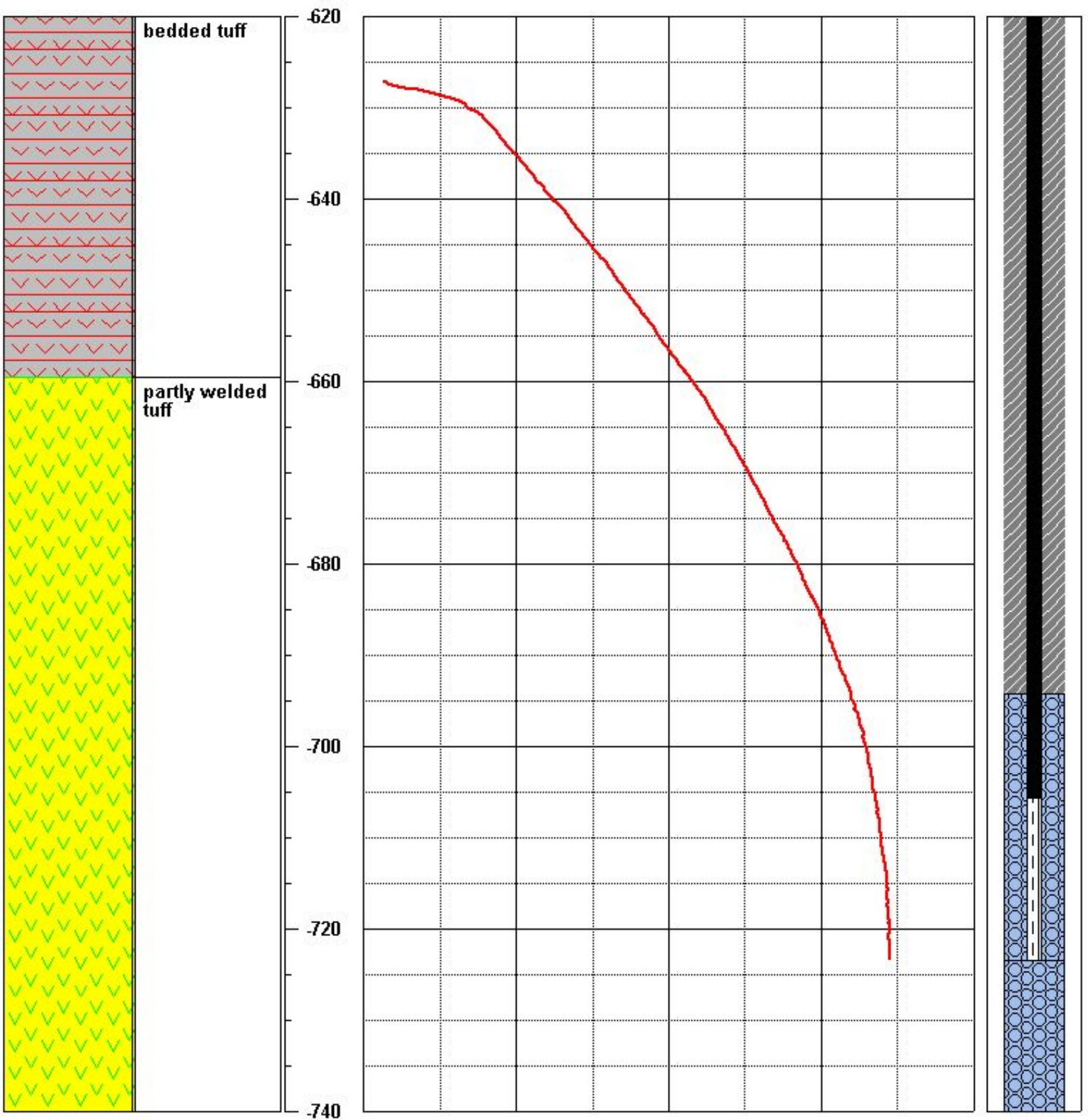

Figure 33. Temperature profile, lithology, and well construction for borehole ER-20-5\#1 string \#2. 
On May 12, 2003, DRI obtained a temperature profile from the second tubing string at ER-20-5\#1 using its PHASe temperature probe. The temperature profile through the bedded tuff units penetrated by the borehole appears fairly linear $\left(\mathrm{R}^{2}=0.999\right)$. A least-squares linear regression of the geothermal gradient over the bedded tuff interval was determined to be $0.0236{ }^{\circ} \mathrm{C} \mathrm{m}^{-1}$. Using a thermal conductivity value of $1.73 \mathrm{~W} \mathrm{~m}{ }^{-1}{ }^{\circ} \mathrm{C}^{-1}$ for the bedded tuff unit (Sass et al., 1987) combined with the geothermal gradient determined from the temperature profile yields a heat flow value of $40.8 \mathrm{~mW} \mathrm{~m}^{-2}$.

Below the bedded tuff, the geothermal gradient within the partly welded tuff gradually decreases until becoming virtually zero within the slotted interval. This gradual decrease in gradient likely reflects the presence of residual heat from a nearby underground nuclear test. This residual heat also likely affects the gradient measured within the bedded tuff unit resulting in a higher heat flow values than would normally be observed. However, given the low thermal and hydraulic conductivities of the bedded tuff unit, the measured heat flow may be somewhat realistic.

\section{ER-20-6\#1 string \#2, ER-20-6\#2 string \#2, and ER-20-6\#3 string \#2}

ER-20-6\#1 (Figure 34a), ER-20-6\#2 (Figure 34b), and ER-20-6\#3 (Figure 34c) were constructed in early 1996, for the BULLION Forced-gradient Experiment. ER-20-6\#1, ER-20-6\#2, and ER-20-6\#3 are located downgradient from the surface-ground-zero for the BULLION underground nuclear test conducted May 13, 1990, at distances of 165.8, 207.3, and $296 \mathrm{~m}$, respectively.

On April 30, 2003, temperature profiles were obtained from the boreholes using DRI's PHASe temperature logging tool. The depth to fluid was measured at approximately $621 \mathrm{~m}$ in all three boreholes. Depth to the top of the slotted interval in boreholes ER-20-6\#1, ER-20-6\#2, and ER-20-6\#3, are 776, 768, and 760, respectively, resulting in approximately 15, 147, and $139 \mathrm{~m}$ of fluid above the tops of the slotted intervals in the respective boreholes.

Due to the impact of the residual heat generated by the BULLION nuclear test, determination of heat flow values from the ER-20-6 well cluster temperature profiles is not possible. Advective transport of that heat can be noted at depths ranging from 675 to $680 \mathrm{~m}$ in ER-20-6\#1 and ER-20-6\#2, the approximate depth of burial for the BULLION test (Gillespie and Russell, 2003; DOE/NV--209). It does not appear that advective transport of heat from the BULLION test had reached ER-20-6\#3 at the time of logging. Although beyond the scope of this investigation, numerical modeling of the horizontal heat flow observed in the three profiles may yield substantial insight into the variations in the thermal conductivity of volcanic tuffs and thermal effects of groundwater flow. In addition, extremely small thermal gradients present across the slotted intervals suggest significant vertical flow within the boreholes or possibly lateral flow within the lava lithology penetrated by the boreholes.

\section{ER-OV-03c, ER-OV-06a, and ER-OV-03a2}

ER-OV-03c (Figure 35a), ER-OV-03a2 (Figure 36a), and ER-OV-06a (Figure 37a) are three of 12 monitoring wells installed at seven sites in and near Oasis Valley by the U.S. Geological Survey during August through October 1997. Completion of these monitoring wells consisted of 7.6-cm-diameter PVC pipe with stainless-steel wrapped screens. Coarse sand was used to gravel pack the screened intervals. Bentonite was used to seal the annular space between the PVC pipe and the borehole from above the gravel pack to above the water table. On April 15, 
2003, all three wells were temperature logged using DRI's PHASe temperature probe. Within the three boreholes, depth to fluid levels was measured as $65.4,48.7$, and $4.69 \mathrm{~m}$, respectively.
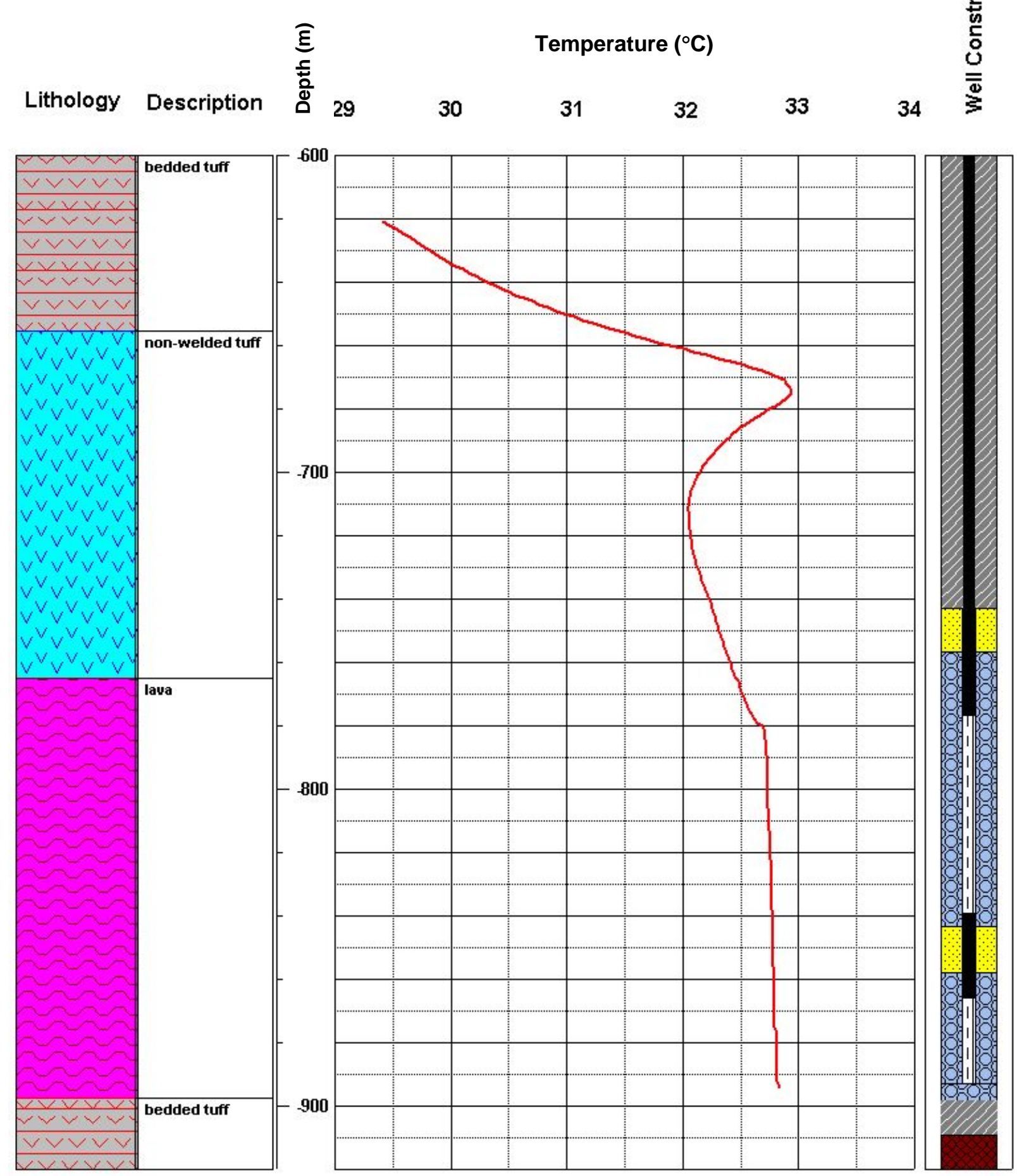

Figure 34a. Temperature profile, lithology, and well construction for borehole ER-20-6\#1 string \#2. 

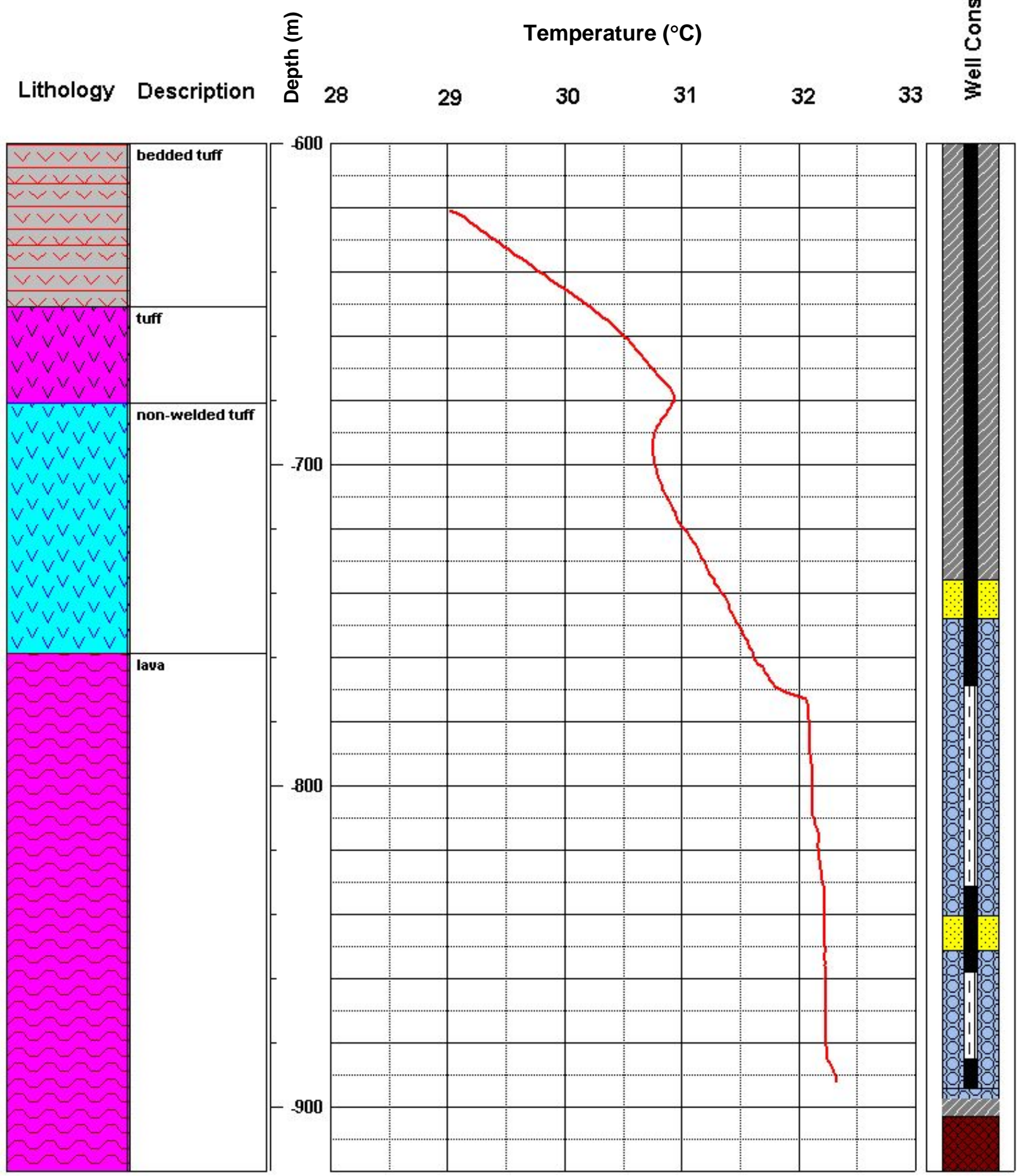

Figure 34b. Temperature profile, lithology, and well construction for borehole ER-20-6\#2 string \#2. 

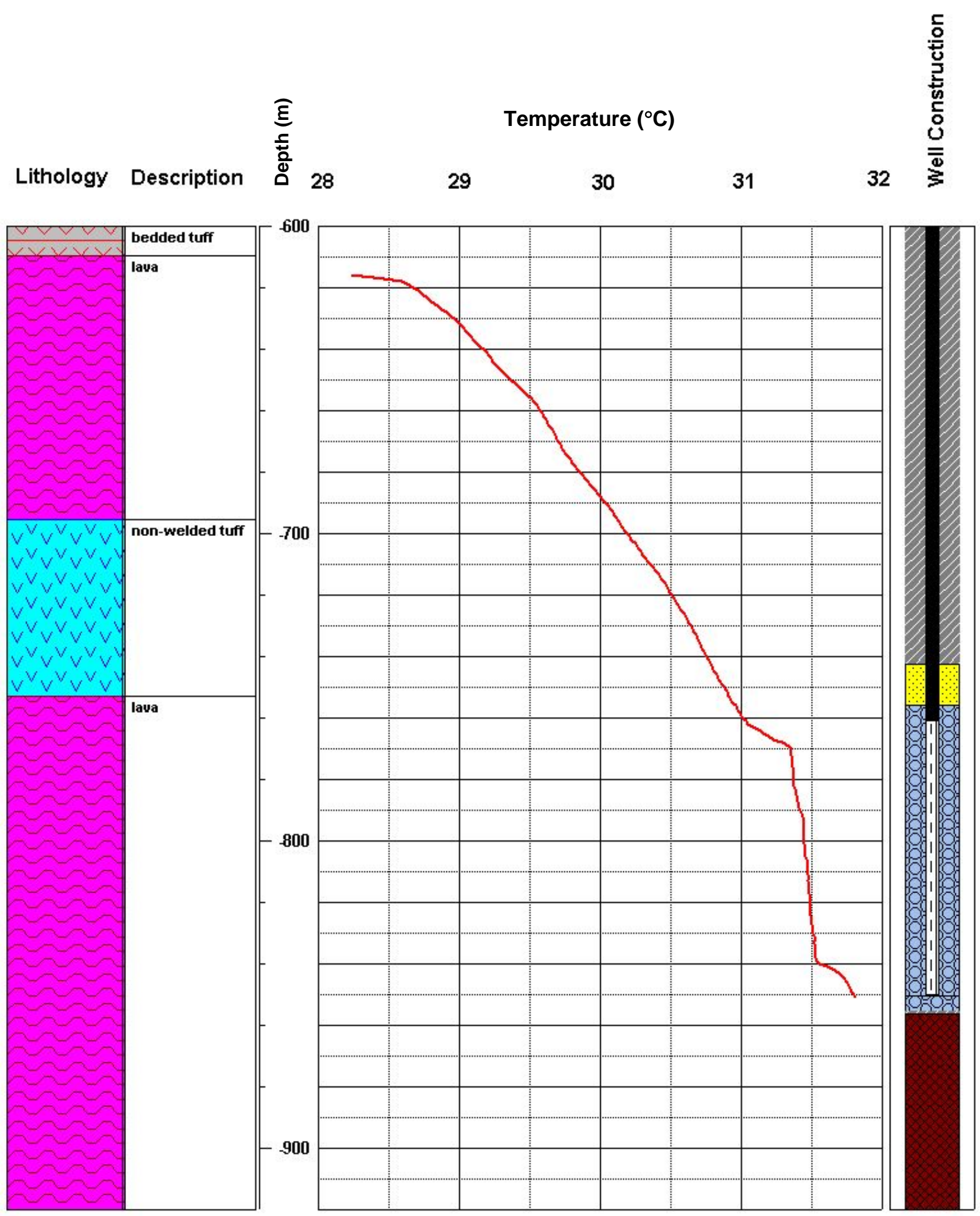

Figure 34c. Temperature profile, lithology, and well construction for borehole ER-20-6\#3 string \#2. 

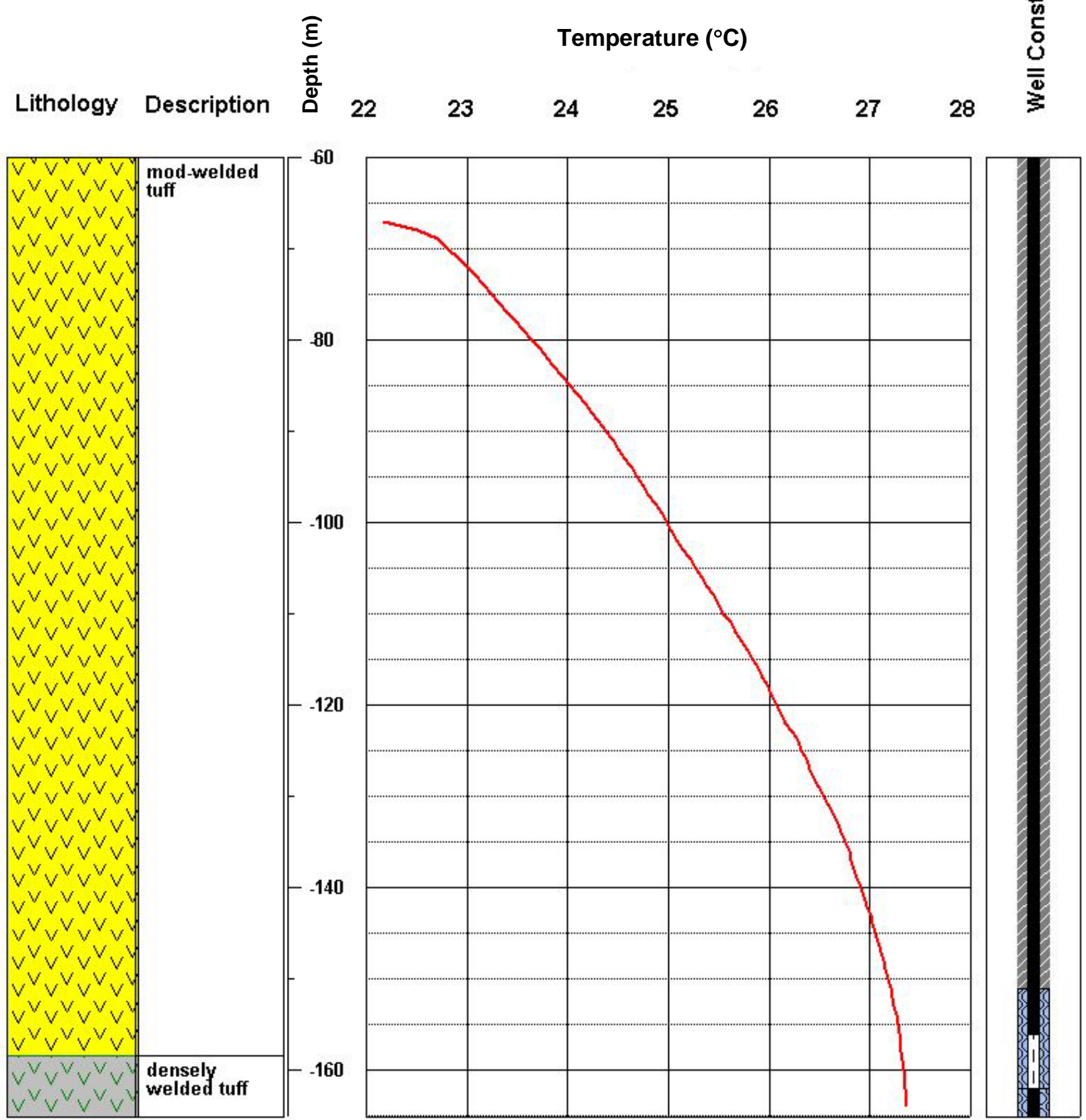

Figure 35a. Temperature profile, lithology, and well construction for borehole ER-OV-03c. 


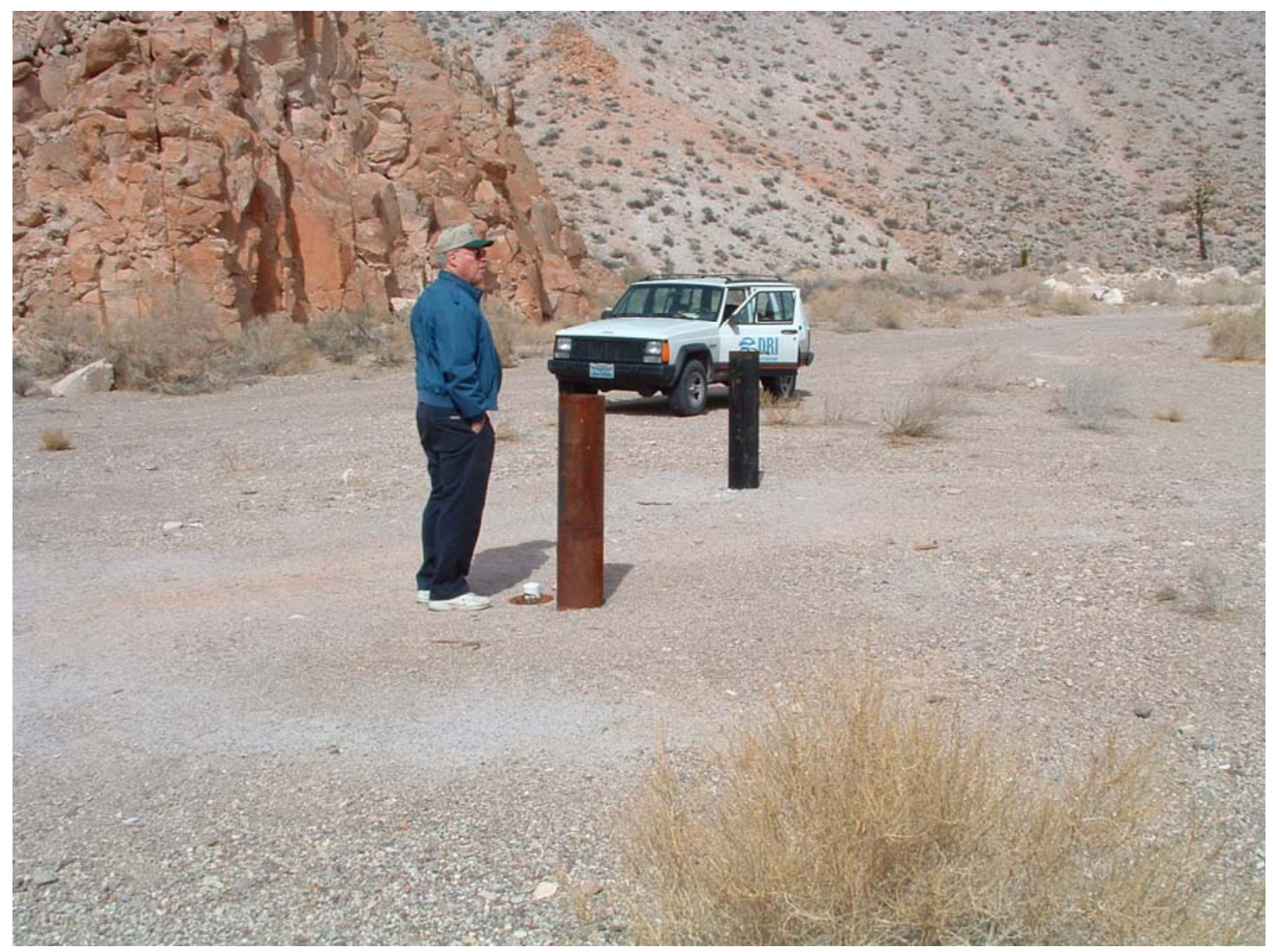

Figure 35b. Location of ER-OV-03c in narrow channel of Beatty Wash.

Temperature profiles from boreholes discussed previously in this investigation were obtained from depths extending several hundred meters or more below ground surface. All three of the ER-OV wells were drilled to a depth of less than $200 \mathrm{~m}$.

The temperature log from ER-OV-03c displays a curved profile from the water table to the bottom of the well. ER-OV-03c is located in a narrow channel of Beatty Wash (Figure 35b). The depth of the curvature displayed in the temperature profile from ER-OV-03c appears to indicate significant increase in apparent thermal conductivity with depth at this location. This increase in thermal conductivity could be the result of increased compaction of the tuff unit penetrated by the borehole or perhaps the effect of heat advection by vertical groundwater flow. Using a simple numerical model developed from the curve-matching technique devised by Bredehoeft and Papadopulos (1965) it was determined that a vertical flow rate of approximately $-0.16 \mathrm{~m} / \mathrm{yr}$ would produce the degree of curvature observed in the ER-OV-3c temperature profile. The nearly vertical gradient observed in the densely welded tuff at the bottom of the borehole may result from significant horizontal groundwater movement within the densely welded tuff. 

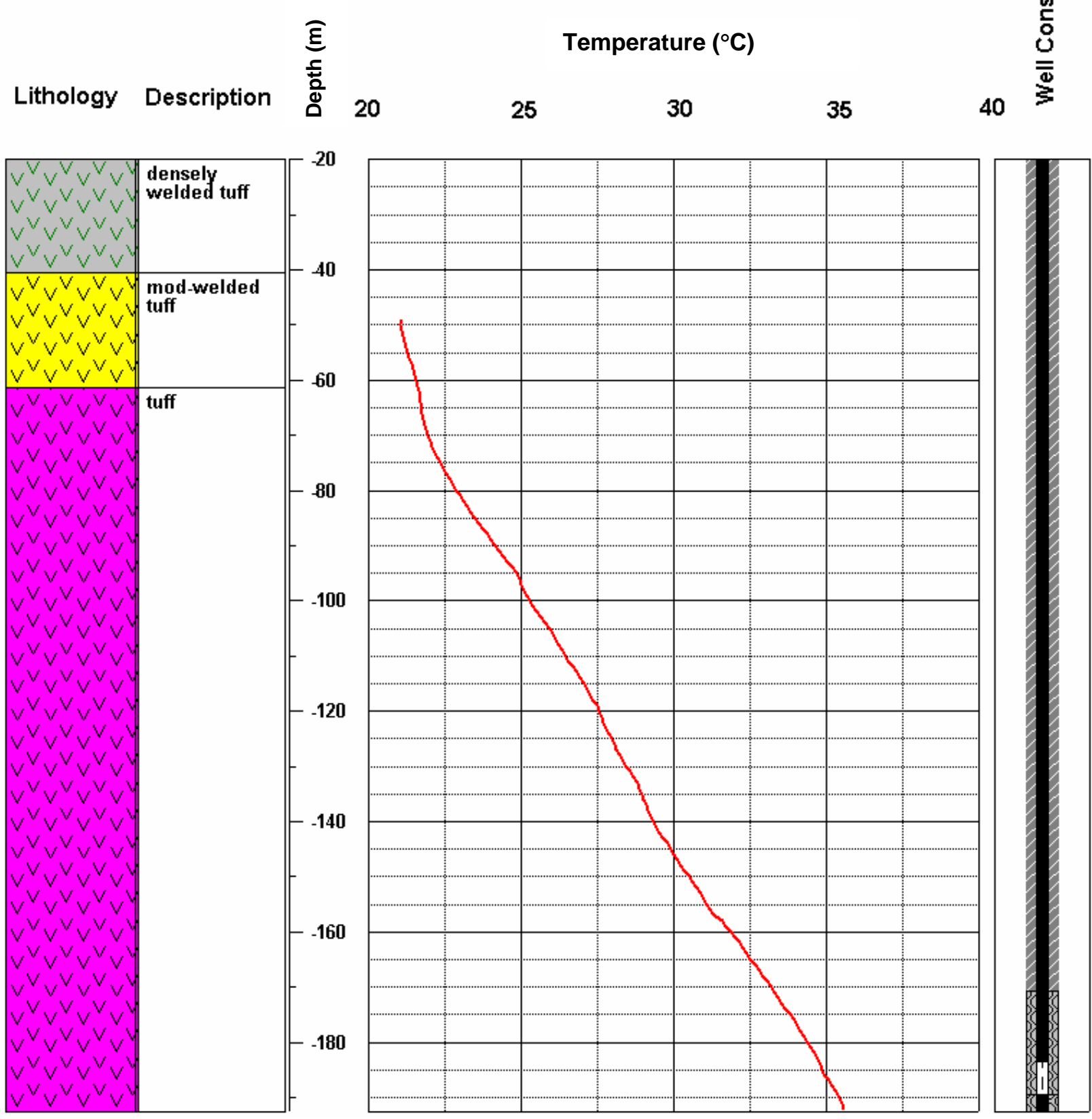

Figure 36a. Temperature profile, lithology, and well construction for borehole ER-OV-03a2. 


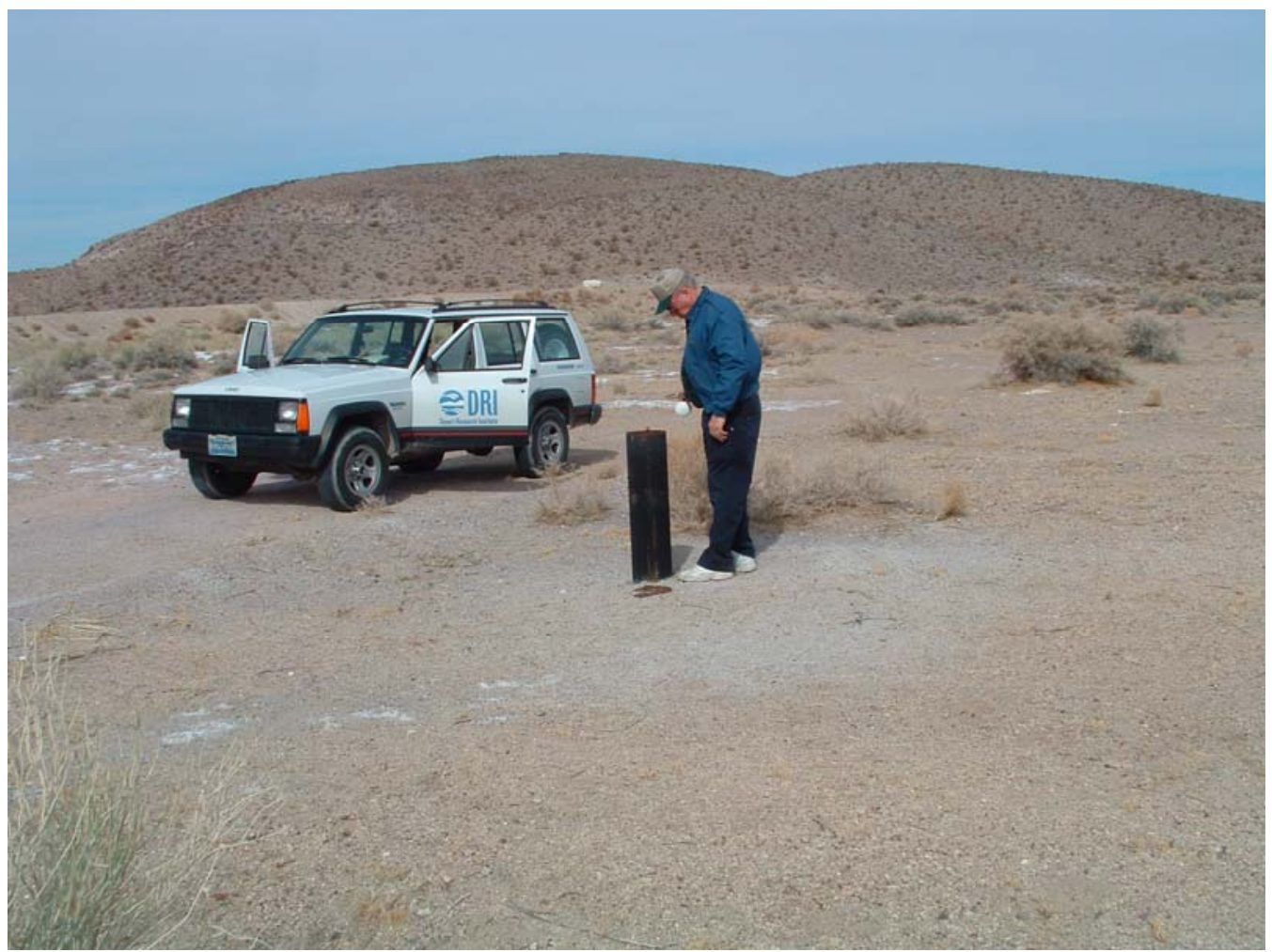

Figure 36b. Location of ER-OV-03a2 near Goss Spring (note evaporative salts on soil surface).

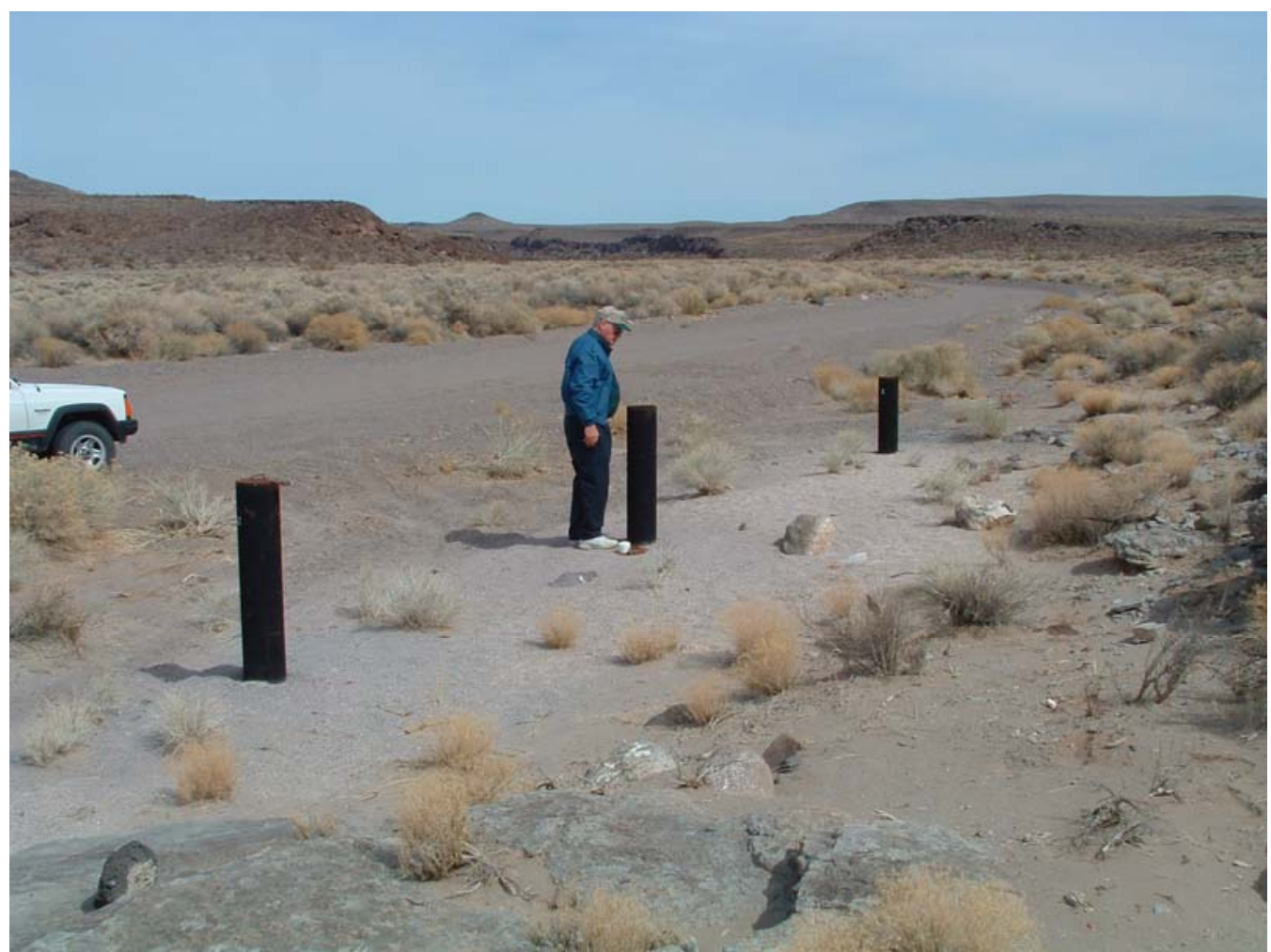

Figure 37a. Location of ER-OV-06a (note Thirsty Canyon in background). 

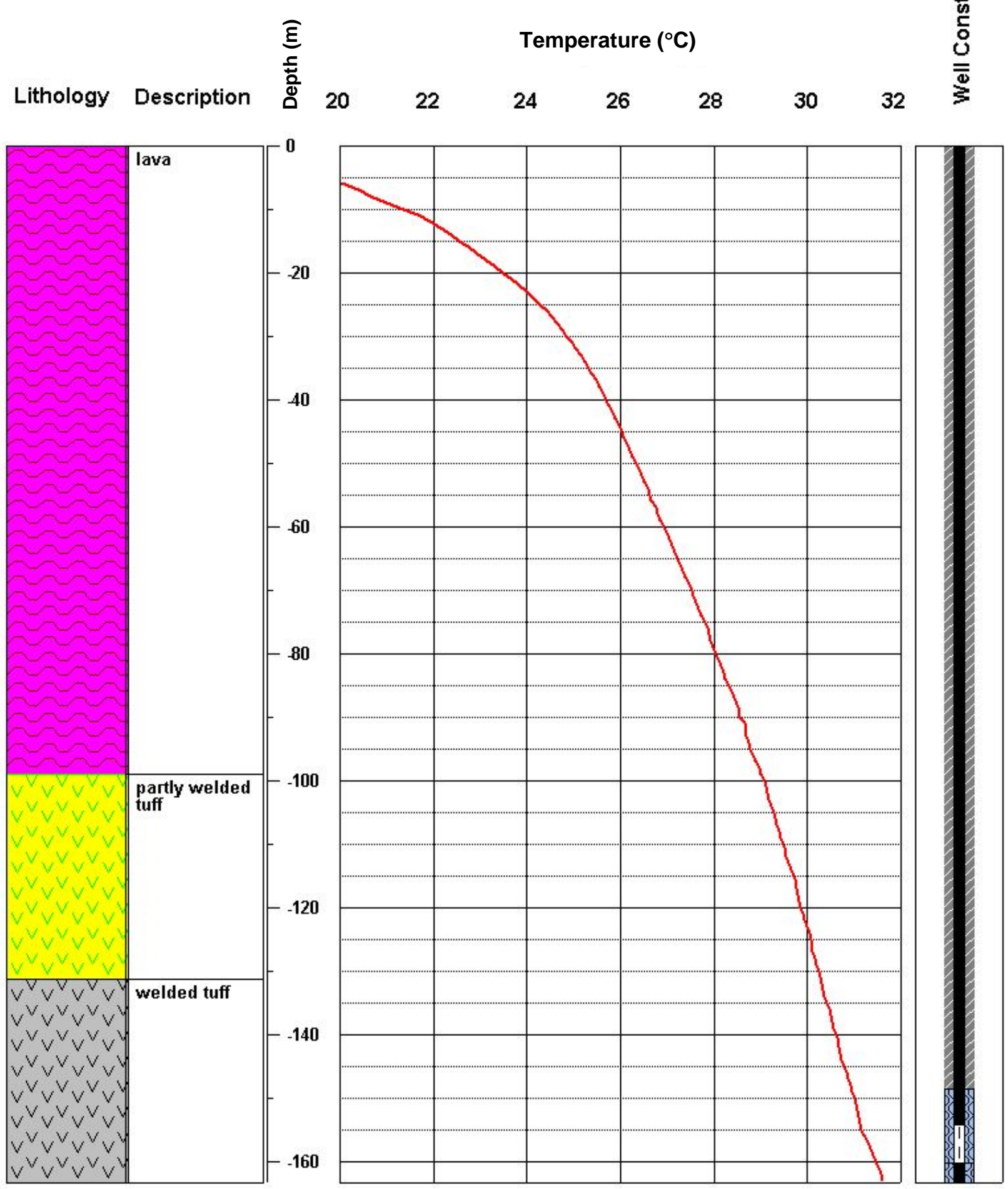

Figure 37b. Temperature profile, lithology, and well construction for borehole ER-OV-06a. 
The linear portion of the temperature profile from ER-OV-03a2 (Figure 36a) extends upward to approximately $70 \mathrm{~m}$. Above the break in gradient at about $70 \mathrm{~m}$, a steeper profile is present. This break from greater to smaller gradient is most likely due to a change in lithology. ER-OV-03a2 is located in close proximity to Goss Spring, where groundwater discharges at land surface (Figure 36b). Additionally, a least-squares regression of the linear portion of the temperature profile from approximately $70 \mathrm{~m}$ to total depth, at ER-OV-03a2, yields a geothermal gradient of $0.1121^{\circ} \mathrm{C} \mathrm{m}^{-1}$. Using a thermal conductivity value of $1.62 \mathrm{~W} \mathrm{~m}^{-1}{ }^{\circ} \mathrm{C}^{-1}$ for the tuff unit (Sass et al., 1987) combined with the geothermal gradient determined from the temperature profile yields a heat flow value of $181.6 \mathrm{~mW} \mathrm{~m}^{-2}$. This relatively high heat flow likely indicates the presence of significant upward fluid movement.

ER-OV-06a is located in a drainage channel south of Thirsty Canyon (Figure 37a). The depth to fluid level in the borehole was measured at $4.69 \mathrm{~m}$ below ground surface.

To interpret the near surface temperature profiles, it is necessary to understand the thermal regime of the shallow subsurface. The annual variation in ground surface temperature is propagated into the shallow subsurface as a sine wave whose amplitude decreases with depth and that is phase shifted by an amount that increases with depth. The depth to which this annual variation in temperature is propagated depends on the thermal properties of the subsurface material as well as the frequency and amplitude of the surface temperature variation. For the annual temperature pulse, in spring, one would expect shallow ground temperature to be less than those at depth; and conversely in fall, one would expect shallow ground temperature to be greater than those at depth. The advection of heat via fluid flow (and vapor flow in the unsaturated zone) can either enhance the propagation (downward flow) or attenuate the propagation (upward flow) of the annual temperature pulse. The maximum depth to which the annual variation in temperature is propagated is reflected as a curvature departure from the linear temperature gradient.

The depth of propagation of the annual temperature variation is readily apparent in the temperature profile above approximately $25 \mathrm{~m}$ below ground surface. The average geothermal gradient of the linear portion of the temperature profile from ER-OV-06a (Figure 37b), below the effect of the annual temperature pulse, is $0.0377^{\circ} \mathrm{C} \mathrm{m}^{-1}$. Using a thickness-weighted composite thermal conductivity value of $1.74 \mathrm{~W} \mathrm{~m}^{-1}{ }^{\circ} \mathrm{C}^{-1}$ for the volcanic units (Sass et al., 1987) penetrated by the borehole combined with the geothermal gradient determined from the temperature profile yields a heat flow value of $65.6 \mathrm{~mW} \mathrm{~m}^{-2}$. Although outside the scope of this report, since the annual temperature pulse is readily observable in the temperature profile from ER-OV-06a, it would be possible to record the yearly change in temperature with depth and determine the presence or absence of vertical groundwater flow in the vicinity of the borehole using numerical modeling techniques.

\section{ER-5-4\#2}

Although not actually part of this investigation, temperature profiles from ER-5-4\#2 (Figure 38) have been obtained by DRI, which, with the continued collection of data, may provide insight into thermal recovery of boreholes following construction. Following the construction and testing of ER-5-4\#2 in November 2002, an initial temperature profile was obtained on December 2, 2002. Three subsequent temperature profiles were obtained on January 4, and March 22, 2003, and May 6, 2004. 
The temperature profiles from ER-5-4\#2 indicate that the bottom hole temperature returns to thermal equilibrium fairly quickly. This would be expected since deeper portions of the borehole were disturbed for a shorter period of time. Also, as would be expected, the return to thermal equilibrium slows with time. With the addition of future data points, it should be possible to predict the final equilibrium profile for the borehole; however, from a purely empirical examination of the data, it appears that the original assumption of the author that approximately one year would be required for a well to return to thermal equilibrium is reasonably accurate for most situations.

Using the latest temperature profile the average geothermal gradient for ER-5-4\#2 is $0.0156{ }^{\circ} \mathrm{C} \mathrm{m}^{-1}$. Using a thickness-weighted composite thermal conductivity value of $1.42 \mathrm{~W} \mathrm{~m}^{-1}$ ${ }^{\circ} \mathrm{C}^{-1}$ for the alluvium and volcanic units (Sass et al., 1987) penetrated by the borehole combined with the geothermal gradient determined from the temperature profile yields a heat flow value of $22.2 \mathrm{~mW} \mathrm{~m}^{-2}$.

\section{UE-6d}

UE-6d (Figure 39) was drilled to a total depth of 1,187.5 $\mathrm{m}$ in May 1968. The borehole was completed with 19.4-cm-diameter casing to a depth of $647.7 \mathrm{~m}$ and cemented in place. Below this casing the borehole is open. Depth to static water level in the well is approximately $462.7 \mathrm{~m}$ below ground surface, resulting in approximately $185 \mathrm{~m}$ of fluid above the base of the casing within the borehole. The saturated portion of the borehole above the bottom of the casing penetrates alluvium.

On June 26, 2003, DRI obtained a temperature profile at UE-6d using its PHASe temperature probe. The history for this borehole reports a lost electrical logging tool in the borehole. A video log of UE-6d performed earlier by DRI revealed no obstruction to a depth of $850 \mathrm{~m}$ (the depth limit for DRI's video logging unit's wireline). To prevent entanglement of the temperature logging tool and any lost logging tools or wireline, which may be in the hole, the temperature profile was halted at a depth of approximately $850 \mathrm{~m}$. A least-squares linear regression of the geothermal gradient over the interval above the base of the casing was determined to be $0.0067^{\circ} \mathrm{C} \mathrm{m}^{-1}$. Using a thermal conductivity value of $1.2 \mathrm{~W} \mathrm{~m}^{-1} \mathrm{C}^{-1}$ for the alluvium combined with the geothermal gradient determined from the temperature profile yields a heat flow value of $8.0 \mathrm{~mW} \mathrm{~m}^{-2}$. The temperature profile above the base of the casing displays a slight concave upward curvature. This curvature maybe indicative of a slow gradual decrease in the thermal conductivity of the alluvium, or may indicate a slight downward fluid flow within the alluvium. A slight downward flow within the alluvium would also be supported by the extremely low heat flow estimated from the thermal profile.

ER-18-2 was completed in May 1999 to a total depth of $762 \mathrm{~m}$ below ground surface. The borehole was completed with casing cemented within the borehole to a depth of $652.7 \mathrm{~m}$; however, a sample pump on 7.3-cm-diameter tubing was left within the borehole with the top of the pump at approximately $453 \mathrm{~m}$ below ground surface. Depth to water level within the well is approximately $369.7 \mathrm{~m}$, resulting in about $83 \mathrm{~m}$ of saturated interval available for temperature logging. 

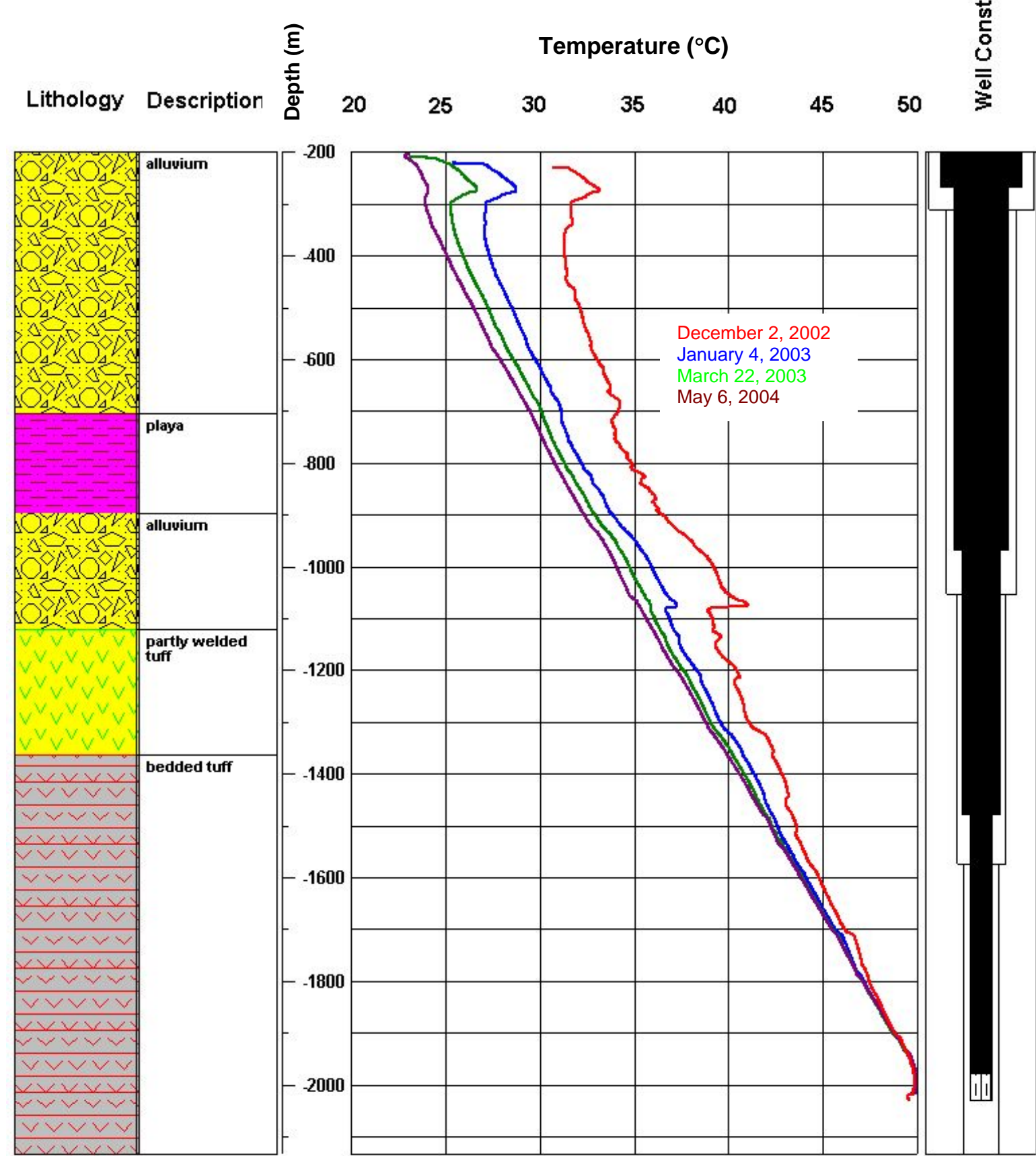

Figure 38. Temperature profiles, lithology, and well construction for borehole from ER-5-4\#2. 

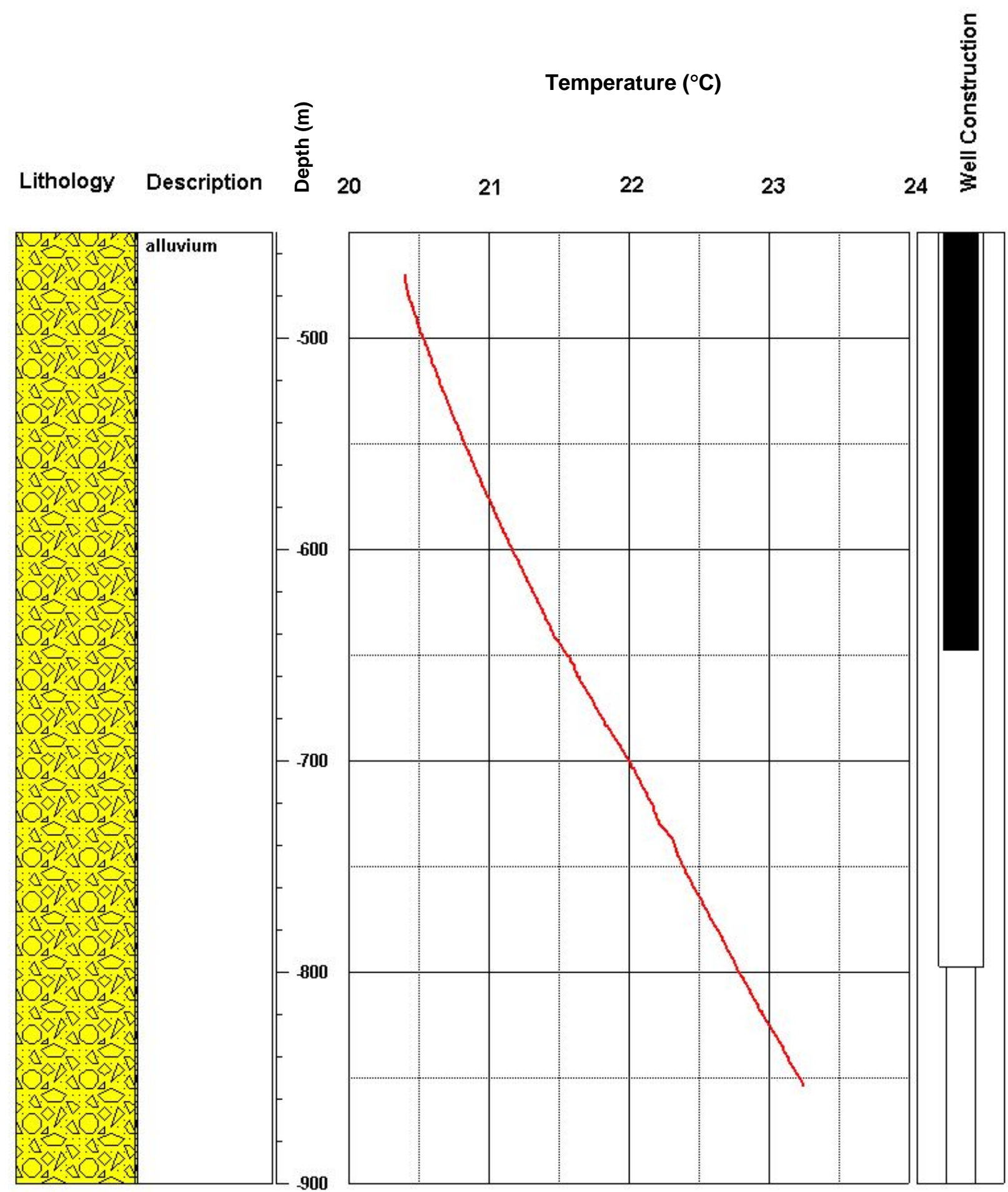

Figure 39. Temperature profile, lithology, and well construction for borehole UE-6d. 


\section{ER-18-2}

On May 24, 2004, DRI obtained a temperature profile from ER-18-2 using DRI's PHASe temperature logging tool (Figure 40). The average geothermal gradient of the temperature profile from ER-18-2 is $0.0329{ }^{\circ} \mathrm{C} \mathrm{m}^{-1}$. Using a thickness-weighted composite thermal conductivity value of $1.71 \mathrm{~W} \mathrm{~m}^{-1}{ }^{\circ} \mathrm{C}^{-1}$ for the volcanic units (Sass et al., 1987) penetrated by the borehole combined with the geothermal gradient determined from the temperature profile yields a heat flow value of $56.3 \mathrm{~mW} \mathrm{~m}^{-2}$. A significant deflection in the temperature profile is apparent from approximately 390 to $410 \mathrm{~m}$ below ground surface. This concave upward deflection may reflect a change in lithology, and thus thermal conductivity, not noted in the lithologic record for this borehole or may indicate the presence of vertical fluid flow. This fluid flow may occur outside the borehole inside the surrounding formation, or there may be flow within the cemented section of the borehole due to insufficient sealing of the cement in the annual space between the casing and the borehole.

\section{ER-12-2}

ER-12-2 (Figure 41) was completed to a total depth of 2,097.9 m in January 2003. The borehole was completed with 33.97-cm-diameter casing to a depth of $901.7 \mathrm{~m}$, below which 31.1-cm-diameter borehole was drilled to total depth. Following development and testing, a packer was run on 7.3-cm-diameter tubing and set at a depth of approximately 1,584 m below ground surface. Following completion, the fluid level has continued to slowly rise within the 7.3-cm-diameter tubing. At the time DRI obtained the temperature profiles, depth to fluid was measured at $56.5 \mathrm{~m}$ below ground surface.

Although obvious breaks in the temperature profile are apparent at approximately $500 \mathrm{~m}$ and 1,100 m, which appear to correlate to changes in lithology, the completion of this well only allows the relatively small section where the casing is cemented within the borehole (823 to $903 \mathrm{~m}$ ) to be used to calculate a geothermal gradient. A least-squares regression of the thermal gradient from ER-12-2 over this interval results in a gradient of $0.0179{ }^{\circ} \mathrm{C} \mathrm{m}^{-1}$. Combined with a estimated thermal conductivity of $4.5 \mathrm{~W} \mathrm{~m}^{-1}{ }^{\circ} \mathrm{C}^{-1}$ (Johnston et al., 1981) for the interbedded quartzite and argillite penetrated by the borehole yields a heat flow value of $80.5 \mathrm{~mW} \mathrm{~m}^{-2}$.

It must also be noted that for this borehole, hole deviation of between 5 and 6 degrees from vertical was present over the interval used to calculate the geothermal gradient. To examine the effect of borehole deviation, the measured temperature data were corrected to true vertical depth and plotted along with the measured temperature data (Figure 41). As can be seen in the temperature profiles, significant borehole deviation only occurred below approximately 1,100 m below ground surface (maximum deviation 54.98 degrees at 1,867 m below ground surface). Although it is evident that significant borehole deviation will result in erroneous measured temperature gradients, comparison of measured and depth-corrected temperature gradients over the interval from 823 to $903 \mathrm{~m}$ did not result in a significant difference. 


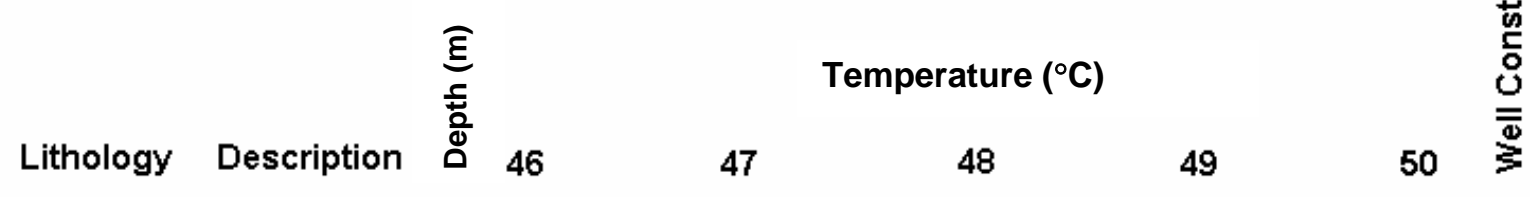

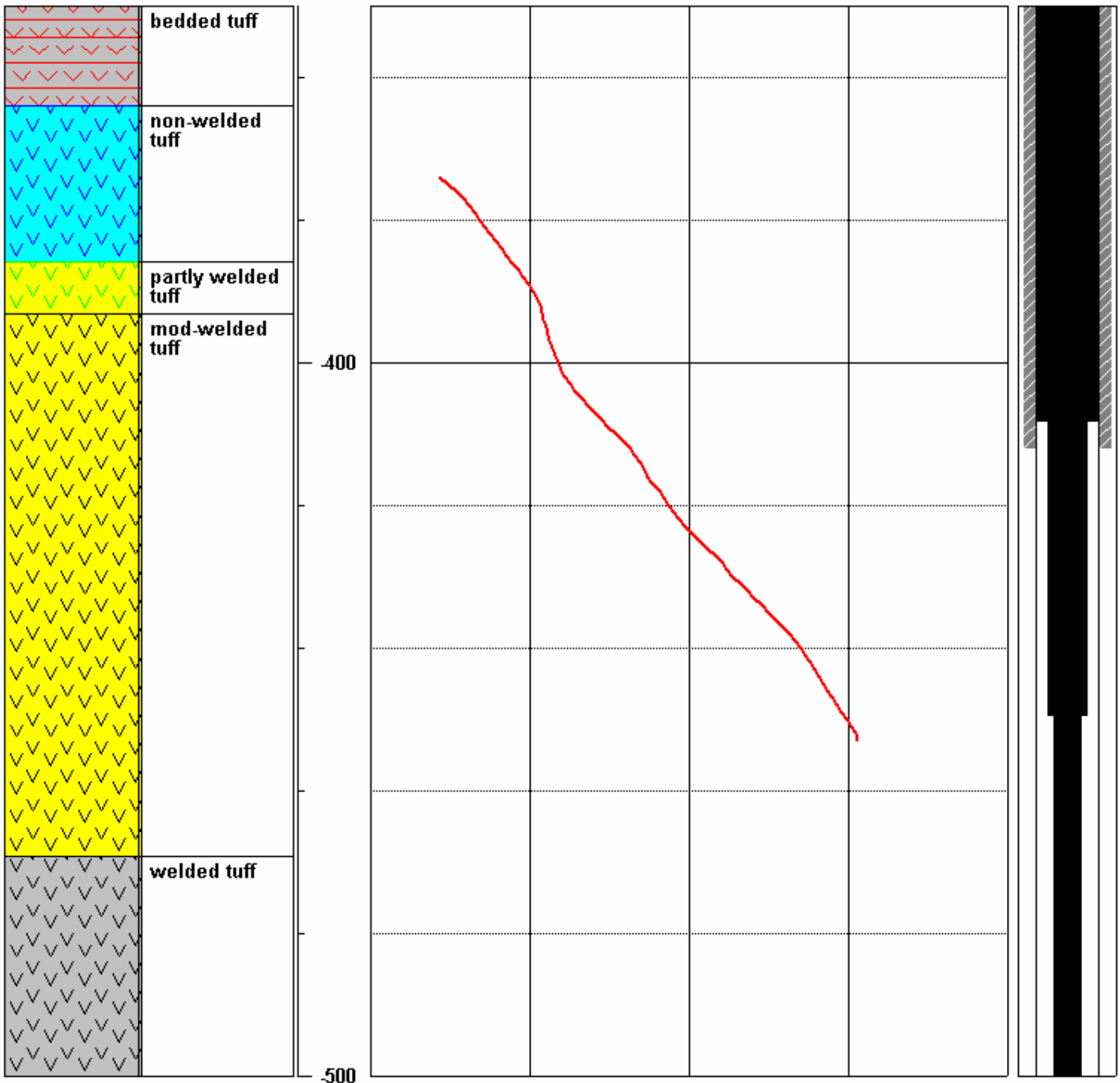

Figure 40. Temperature profile, lithology, and well construction for borehole ER-18-2. 


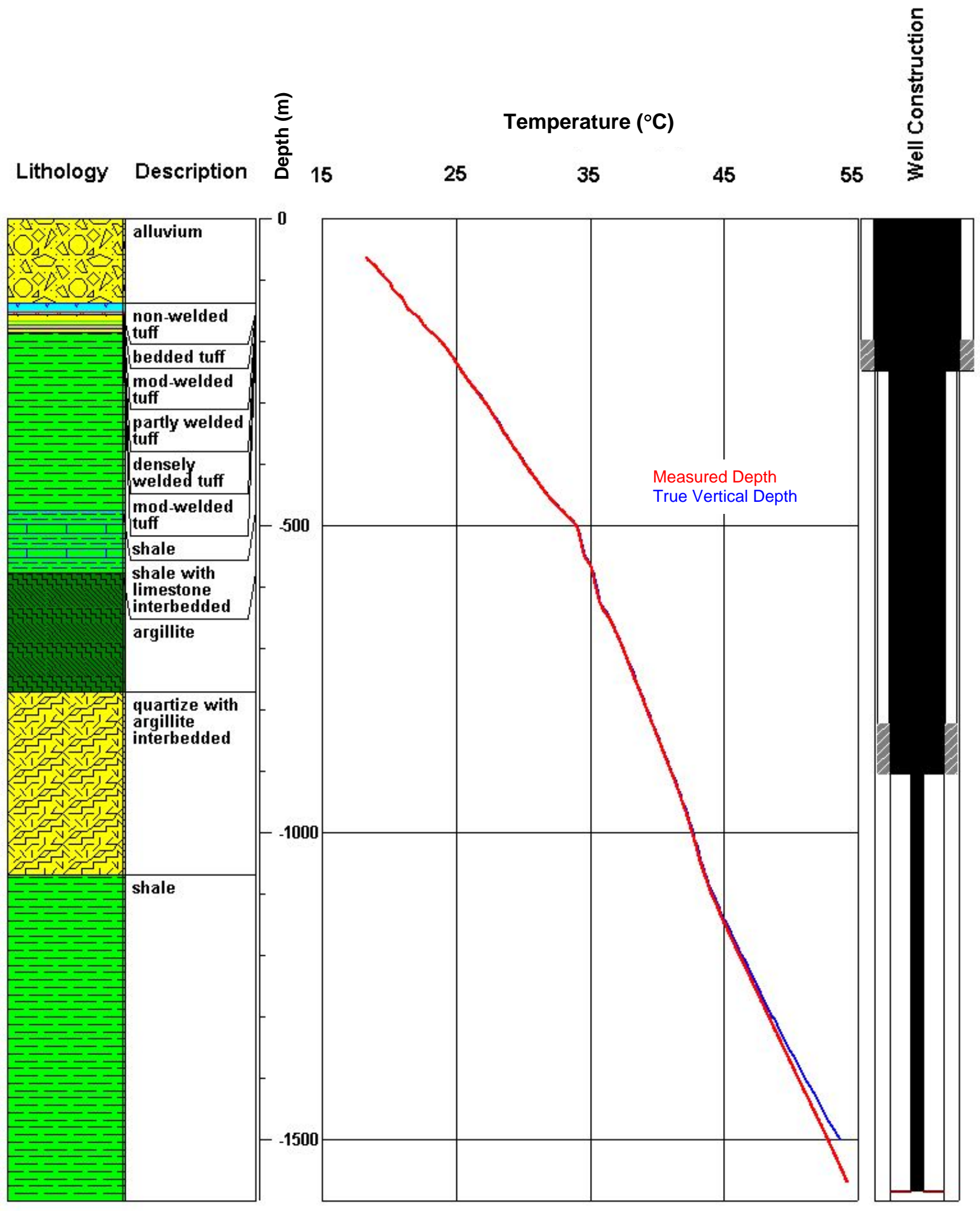

Figure 41. Temperature profile, lithology, and well construction for borehole ER-12-2. 


\section{ER-2-1}

ER-2-1 (Figure 42) was completed to a total depth of $792.5 \mathrm{~m}$ in March 2003. The borehole was completed using 19.4-cm-diameter casing. This casing contained a slotted interval from 760.6 to $779.4 \mathrm{~m}$ below ground surface. The casing was placed above fill within the borehole and gravel pack was then placed around and above the slotted interval. Above the gravel pack, cement was placed from $705 \mathrm{~m}$ to a depth of $663.5 \mathrm{~m}$ below ground surface. Depth to fluid level in the borehole was measured at $502.6 \mathrm{~m}$ below ground surface.

On April 27, 2004, DRI obtained a temperature profile from ER-2-1 using DRI's PHASe temperature logging tool. Due to the potential for annular flow impacting the temperature profile, as seen in the interval from 520 to $595 \mathrm{~m}$, only the portion of the borehole between 663.5 and $705 \mathrm{~m}$ below ground surface was used to determine a geothermal gradient. A least-squares regression of the thermal gradient from ER-2-1 over this interval results in a gradient of $0.0189{ }^{\circ} \mathrm{C} \mathrm{m}^{-1}$. Combined with a thermal conductivity of $1.73 \mathrm{~W} \mathrm{~m}^{-1}{ }^{\circ} \mathrm{C}^{-1}$ (Sass et al., 1987) for the bedded tuff penetrated by the borehole yields a heat flow value of $32.7 \mathrm{~mW} \mathrm{~m}^{-2}$.

\section{ER-6-1}

ER-6-1 (Figure 43) was originally drilled in 1992, to a depth of $648.9 \mathrm{~m}$ below ground surface. In November 1994, the borehole was deepened to $977.3 \mathrm{~m}$ by drilling a 13.97-cm-diameter core hole. During the initial drilling in 1992, 33.97-cm-diameter casing was cemented within the borehole to a depth of $547.1 \mathrm{~m}$ below ground surface.

On October 16, 2003, DRI obtained a thermal profile from ER-6-1 using DRI's PHASe temperature logging tool. A linear regression of the temperature profile through the bedded tuff unit located above the base of the casing within the borehole yields a geothermal gradient of $0.0308^{\circ} \mathrm{C} \mathrm{m}^{-1}$. Combined with a thermal conductivity of $1.73 \mathrm{~W} \mathrm{~m}^{-1}{ }^{\circ} \mathrm{C}^{-1}$ (Sass et al., 1987) for the bedded tuff penetrated by the borehole yields a heat flow value of $53.3 \mathrm{~mW} \mathrm{~m}^{-2}$. As noted in boreholes UE-1q and Water Well 2, there is a marked change in the gradient, due to the change in thermal conductivity between the overlying volcanic units and the underlying carbonate lithology.

\section{U-15K}

U-15k (Figure 44) was drilled as an exploration borehole within the Climax granite stock in 1979 to a total depth of $251.0 \mathrm{~m}$ below ground surface. Measured depth to fluid within the borehole was $230 \mathrm{~m}$ below ground surface. Although completed as an open borehole, hydraulic testing indicates U-15k to be located within a granite with extremely low hydraulic conductivity and thus should yield a geothermal gradient representative of actual formation temperatures. Also, although the hole history for U-15k indicates a total depth of $251.0 \mathrm{~m}$, during temperature logging, DRI measured the total depth of the borehole to be $260.5 \mathrm{~m}$ below ground surface.

On October 16, 2003, DRI obtained a thermal profile from U-15k using DRI's PHASe temperature logging tool. A linear regression of the temperature profile from U-15k yields a geothermal gradient of $0.0192{ }^{\circ} \mathrm{C} \mathrm{m}^{-1}$. The thermal conductivity of granite varies from 1.7 to $4.0 \mathrm{~W} \mathrm{~m}^{-1}{ }^{\circ} \mathrm{C}^{-1}$ (Johnston et al. 1981). These thermal conductivity extremes combined with the thermal gradient would yield heat flow values of 32.6 and $76.8 \mathrm{~mW} \mathrm{~m}^{-2}$ respectively. Using an average value for the thermal conductivity of the granite of $2.85 \mathrm{~W} \mathrm{~m}^{-1} \circ \mathrm{C}^{-1}$ would result in a heat flow value of $54.7 \mathrm{~mW} \mathrm{~m}^{-2}$. 


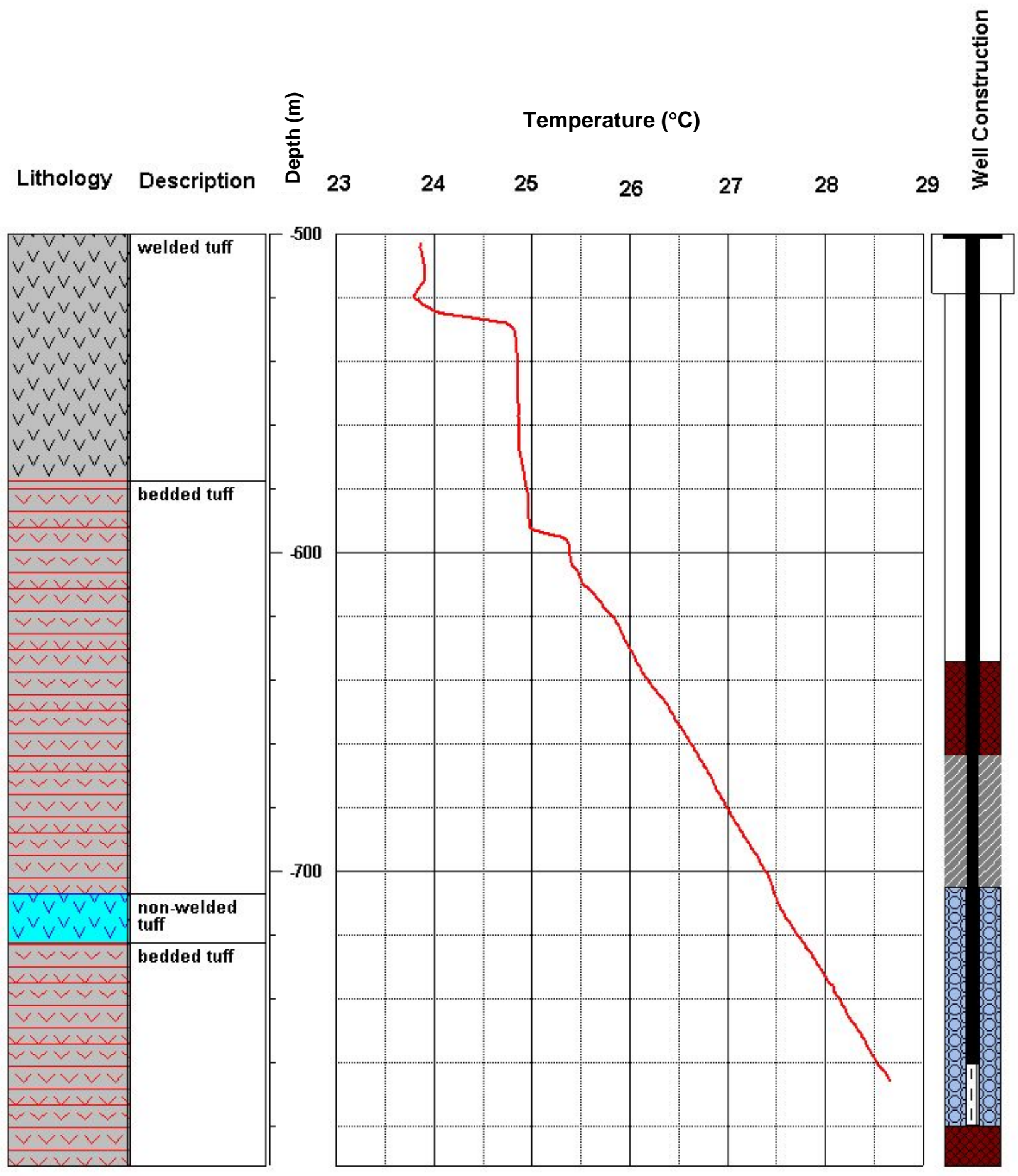

Figure 42. Temperature profile, lithology, and well construction for borehole ER-2-1. 


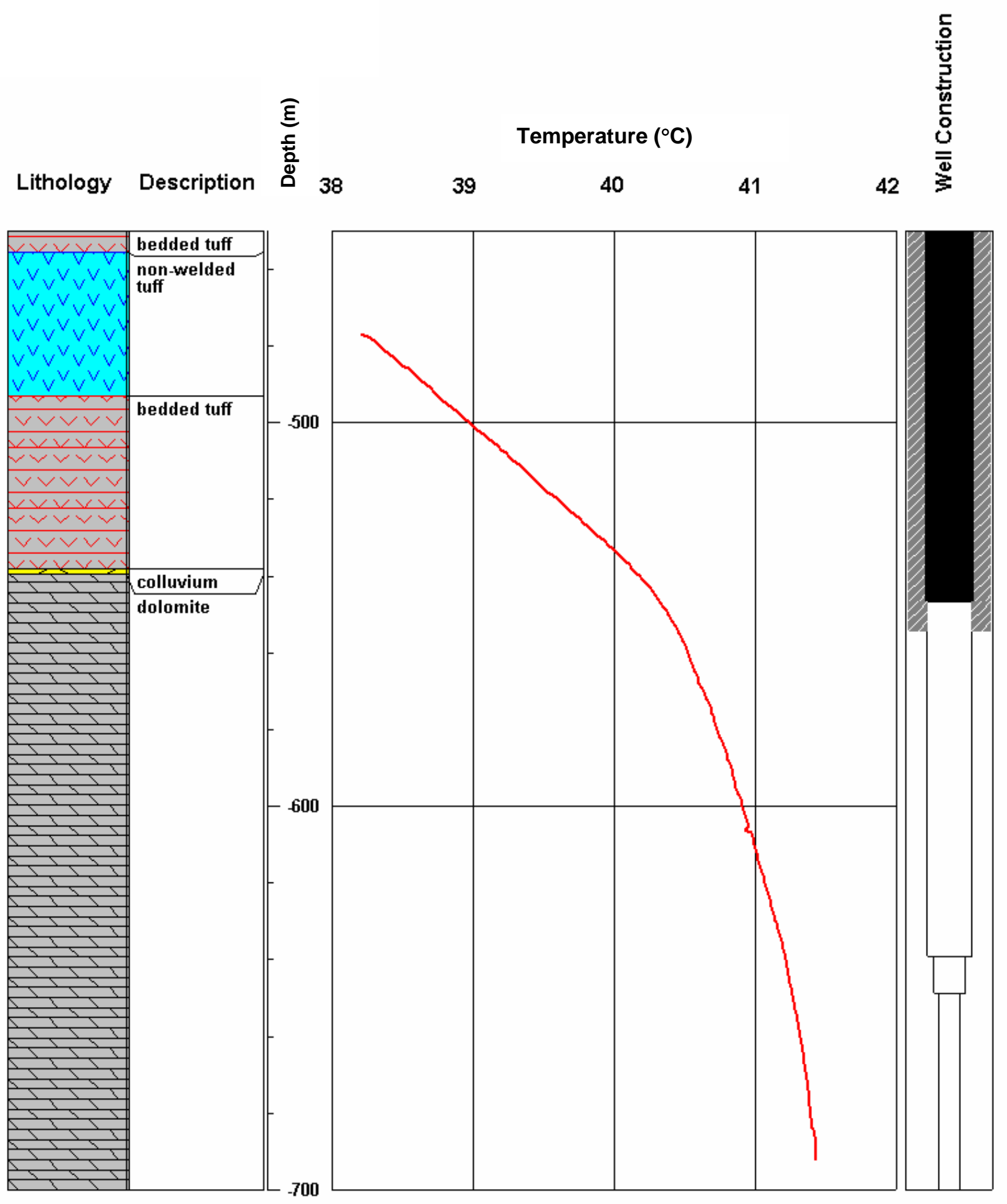

Figure 43. Temperature profile, lithology, and well construction for borehole ER-6-1. 

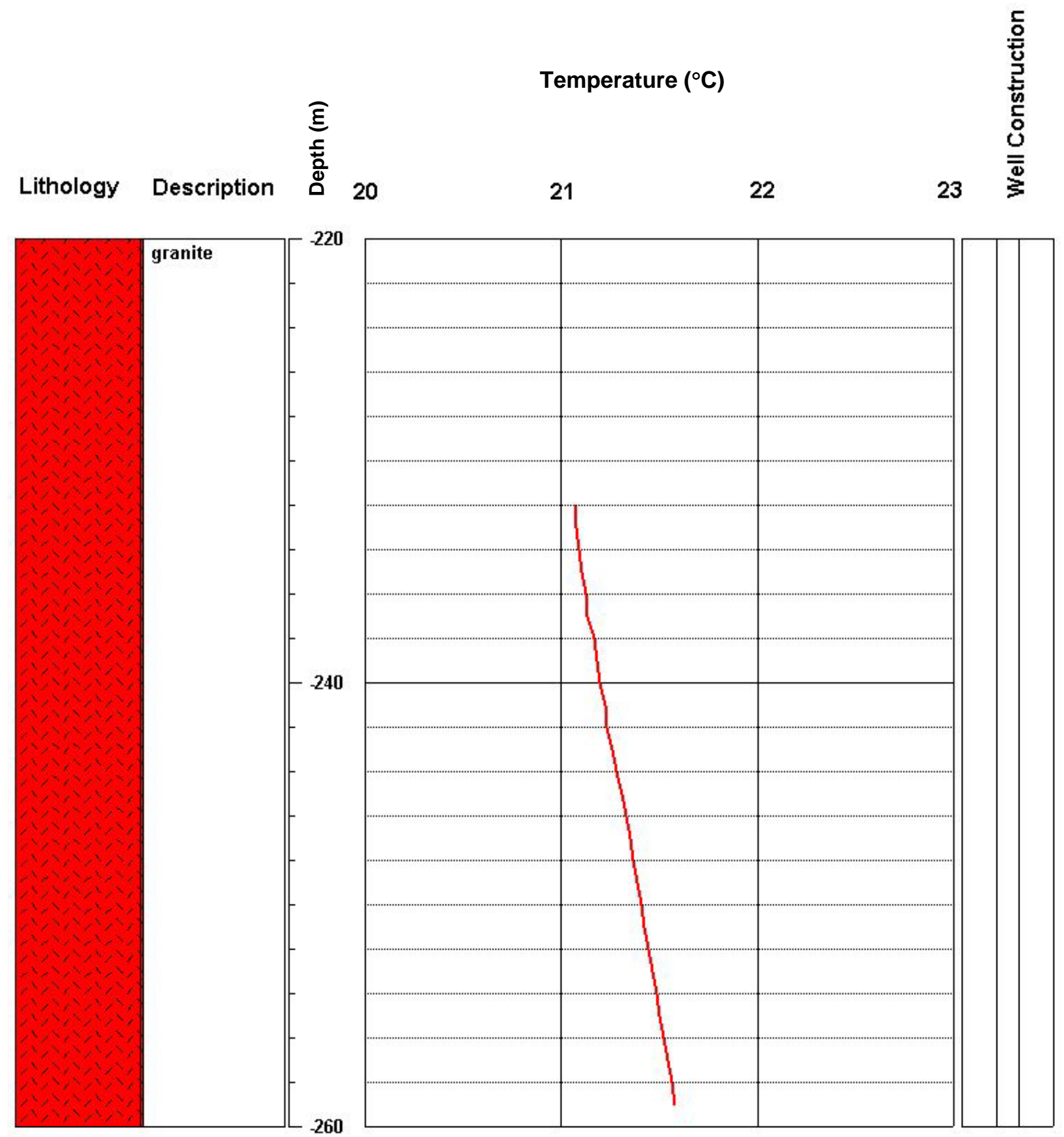

Figure 44. Temperature profile, lithology, and well construction for borehole U-15k. 


\section{TW-D}

TW-D (Figure 45) was drilled as a groundwater test hole in January 1961 to a total depth of 594.4 m below ground surface. During construction of TW-D, 32.4-cm-diameter casing was cemented within the borehole to a depth of $518.2 \mathrm{~m}$. Below this casing, a 27.3-cm-diameter liner was hung from $502.9 \mathrm{~m}$ to a depth of $579.1 \mathrm{~m}$. This liner contained a slotted interval from 540.1 to $573.6 \mathrm{~m}$. Depth to fluid within the borehole is $526 \mathrm{~m}$ below ground surface.

An initial temperature profile was obtained from TW-D by DRI using DRI's Chemtool on August 29, 1994. On April 22, 2004, DRI obtained a second temperature profile from TW-D using DRI's PHASe temperature logging tool (Figure 45). These temperature profiles were obtained entirely within a portion of the borehole where the liner is not cemented and is perforated, permitting fluid flow within the liner and in the annular space between the liner and the borehole and thus are not suitable for determining geothermal gradients. However, it is interesting to note that the two profiles, obtained approximately 10 years apart, are remarkably similar. A cross plot of the two profiles yields a slope of 1.188 with a correlation coefficient of 0.9661. Considering the temperature profiles are only approximately $52 \mathrm{~m}$ long and only vary by 0.5 degrees, the agreement between the two profiles is fairly good.

\section{ASH-B, LWS-A, and MSH-C}

ASH-B, LWS-A, and MSH-C are located southwest of the NTS and were drilled as mineral exploration boreholes by U.S. Borax. Following construction of the three 14.3-cm-diameter boreholes, the wells were completed by the DOE UGTA program as groundwater monitoring locations. Completion consisted of the installation of piezometer tubes with slotted intervals. The slotted intervals were gravel packed and the annular space above and between the piezometer tubes and the borehole cemented to the surface. LWS-A and MSH-C were completed in November 1994. ASH-B was completed in December 1994. The depths to fluid levels within the boreholes are 95.7, 38.5 , and -0.33 m for ASH-B, LWS-A, and MSH-C, respectively.

Following completion, initial temperature profiles were obtained by DRI on May 11, 1995, using DRI's 20-pulse-temperature tool. Subsequent temperature profiles were obtained on March 10, 2004, using DRI's PHASe temperature logging tool.

The temperature profiles from ASH-B (Figure 46) show the effect of lack of thermal equilibration in the initial temperature profile obtained approximately five months after completion of the borehole. As one would expect (and noted previously in the temperature profiles from ER-5-4\#2), there is very little difference in the temperature profile near the bottom of the borehole. The profile also indicates a zone at approximately 215 to $240 \mathrm{~m}$ below ground surface that appears to have been more transmissive, thus absorbing more drilling fluid and producing a cooler zone in the initial temperature profile.

Using the temperature profile obtained from ASH-B with DRI's PHASe logging tool, the average thermal gradient over the logged interval was determined to be $0.0256{ }^{\circ} \mathrm{C} \mathrm{m}^{-1}$. The harmonic mean of the thermal conductivity of the volcanic units over the logged interval of $1.36 \mathrm{~W} \mathrm{~m}^{-1}{ }^{\circ} \mathrm{C}^{-1}$ (Sass et al., 1987) combined with the geothermal gradient determined from the temperature profile yields a heat flow value of $34.7 \mathrm{~mW} \mathrm{~m}^{-2}$. 

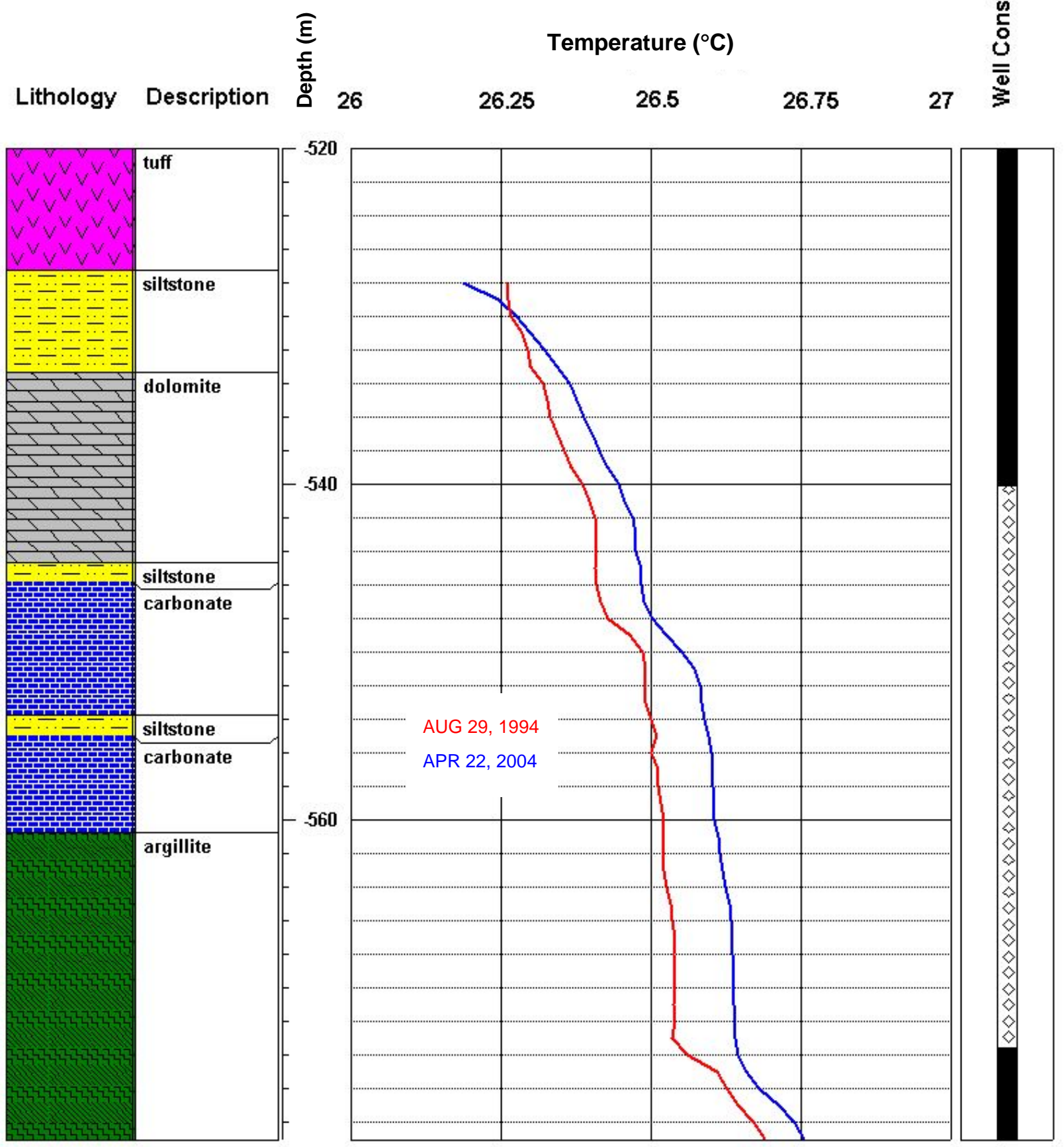

Figure 45. Temperature profile, lithology, and well construction for borehole TW-D. 

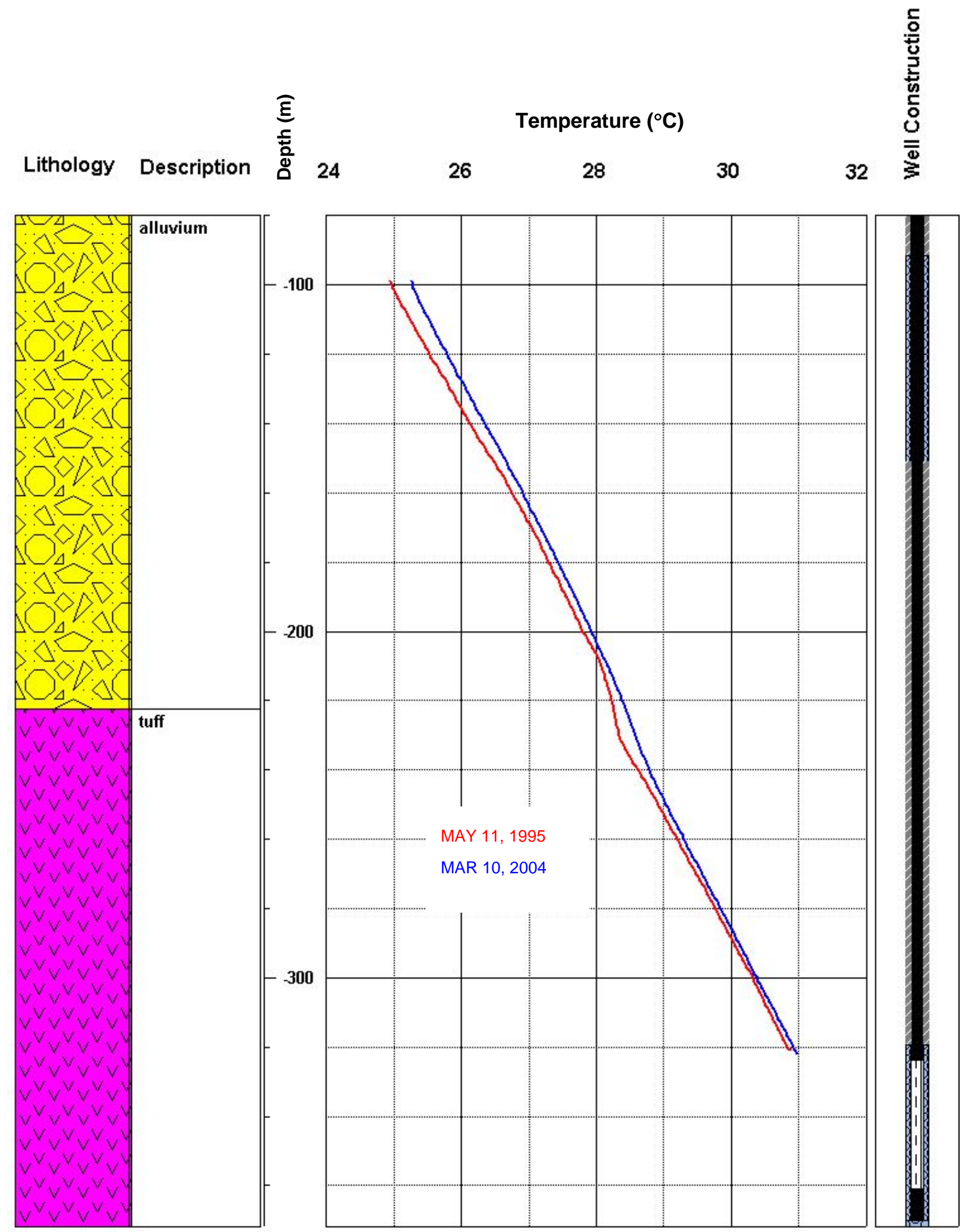

Figure 46. Temperature profiles, lithology, and well construction for borehole ASH-B. 
In the temperature profiles from LWS-A (Figure 47), the thermal equilibration of the borehole is virtually complete with only the upper approximately $100 \mathrm{~m}$ displaying a significant difference in temperature. A slight difference in temperature is also apparent in the lower portion of the sandstone unit located between approximately 300 to $385 \mathrm{~m}$ below ground surface. This zone may be more transmissive than the siltstones above and below and thus absorbed more drilling fluid during the construction of the borehole and required longer to equilibrate.

Using the temperature profile obtained from LWS-A with DRI's PHASe logging tool, the average thermal gradient over the logged interval was determined to be $0.0333^{\circ} \mathrm{C} \mathrm{m}^{-1}$. The harmonic mean of the thermal conductivity of the clastic units over the logged interval of $2.06 \mathrm{~W} \mathrm{~m}^{-1}{ }^{\circ} \mathrm{C}^{-1}$ (Wright and Louden, 1989) combined with the geothermal gradient determined from the temperature profile yields a heat flow value of $68.7 \mathrm{~mW} \mathrm{~m}^{-2}$.

The temperature profiles from MSH-C (Figure 48) appear virtually parallel with the exception of a slightly greater difference in temperature in the upper $100 \mathrm{~m}$. This is apparently due to an approximately $0.28{ }^{\circ} \mathrm{C}$ calibration error in the data from the 20-pulse temperature tool. The temperature profile from MSH-C is difficult to interpret. A least-squares regression over the portion of the temperature profile below the basalt unit results in a geothermal gradient of $0.0093{ }^{\circ} \mathrm{C} \mathrm{m}^{-1}$. Combined with a thermal conductivity of the alluvium of $1.2 \mathrm{~W} \mathrm{~m}^{-1}{ }^{\circ} \mathrm{C}^{-1}$ (Gillespie et al., 1995) results in a heat flow value of $11.2 \mathrm{~mW} \mathrm{~m}^{-2}$. Above the basalt unit the temperature gradient becomes negative above about $50 \mathrm{~m}$ below ground surface. This gradient reversal may be the result of cooler groundwater flowing through a shallow alluvium aquifer above the basalt unit. This shallow alluvium aquifer would be recharged by local precipitation upgradient in the western end of the Spring Mountains. Additionally, MSH-C is located only several kilometers upgradient from discharge areas in Ash Meadows. Groundwater flow with the associated mixing of pore fluids may have the effect of lowering the apparent thermal conductivity of the sediments producing the relatively low heat flow calculated for MSH-C.

\section{DISCUSSION OF CALCULATED HEAT FLUX VALUES}

\section{Comparison to Previous Studies}

Figures 49 and 50, and Table 5, show the location and heat flow values of the 41 boreholes investigated in this study. The only heat flow values calculated from boreholes common between this investigation and the investigation of Sass and Lachenbruch (1982) are boreholes PM-1 and U-15k.

Sass and Lachenbruch (1982) calculated a heat flow value of $42 \mathrm{~mW} \mathrm{~m}^{-2}$ (Table 1) for borehole PM-1; the current investigation calculated a heat flow value for PM-1 of $36.2 \mathrm{~mW} \mathrm{~m}^{-2}$. These heat flow values only differ by $5.8 \mathrm{~mW} \mathrm{~m}^{-2}$ and are in reasonably good agreement. However, as stated previously, thermal conductivity, due to compaction, increases with depth. If a shallower portion of the temperature profile from PM-1 had been analyzed, the calculated heat flow would have been greater. For deep temperature profiles, average thermal conductivities may not be adequate, and an allowance will have to be made to account for the increased thermal conductivity of various lithologies with depth. 

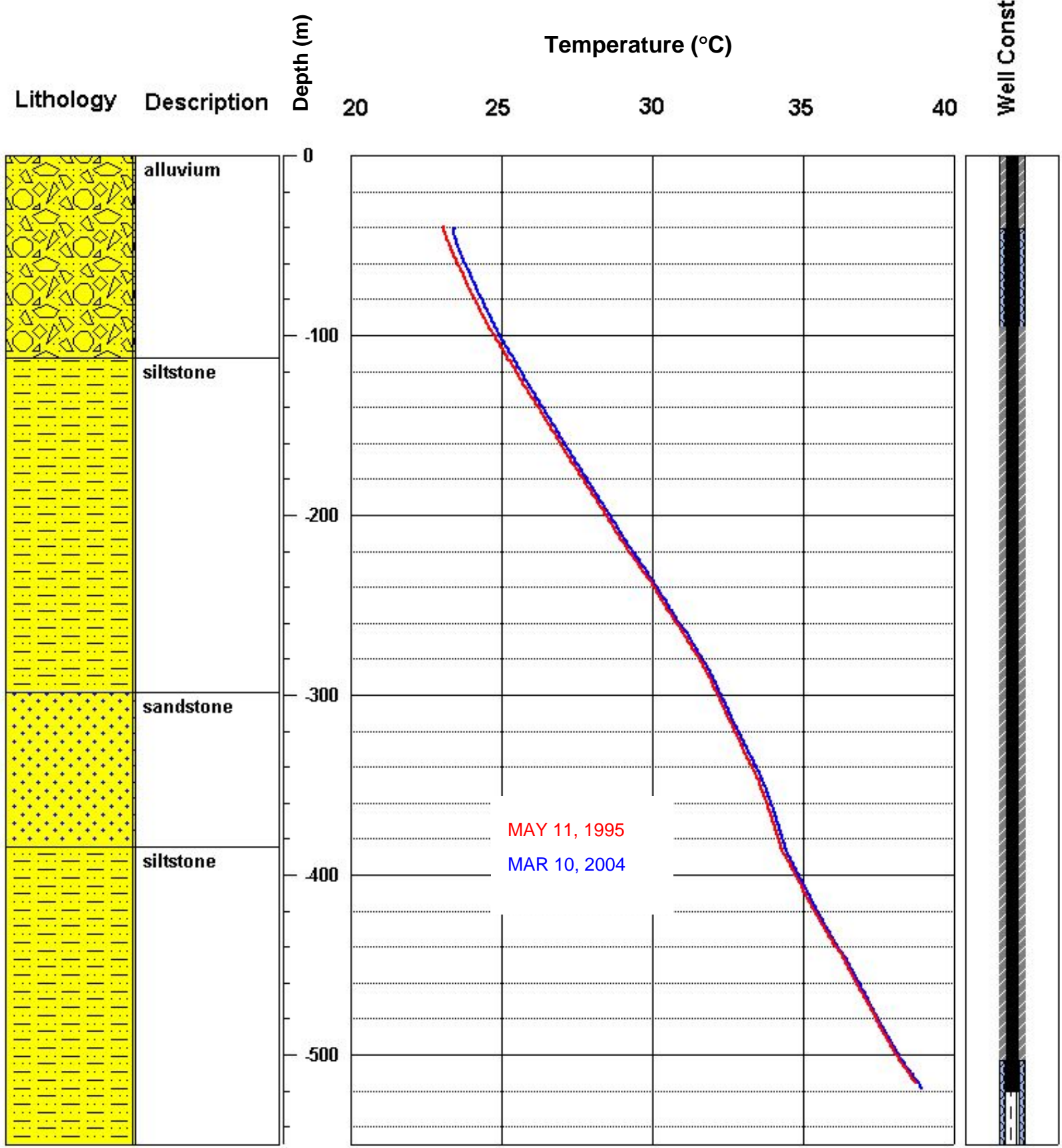

Figure 47. Temperature profiles, lithology, and well construction for borehole LWS-A. 

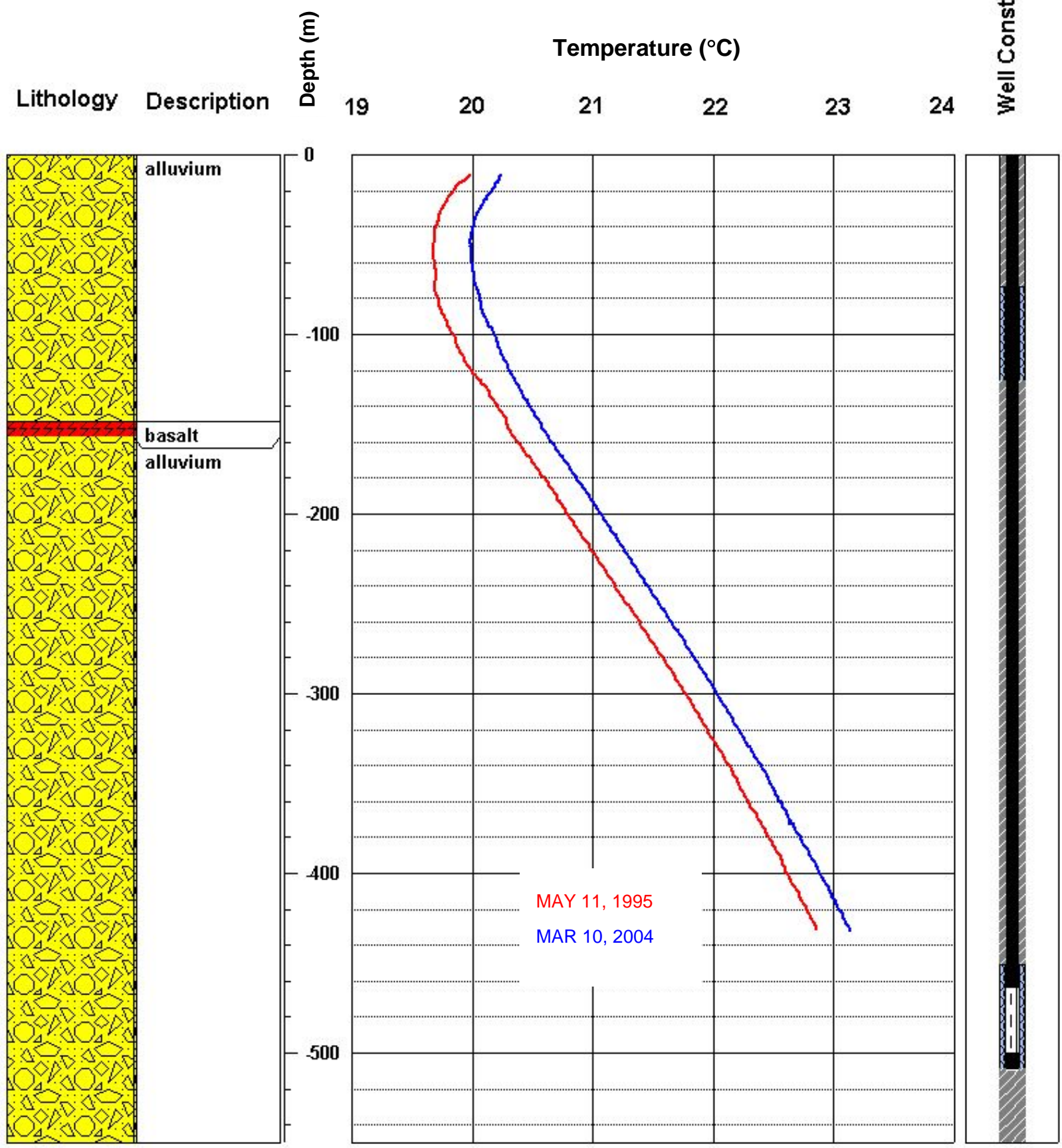

Figure 48. Temperature profiles, lithology, and well construction for borehole MSH-C. 


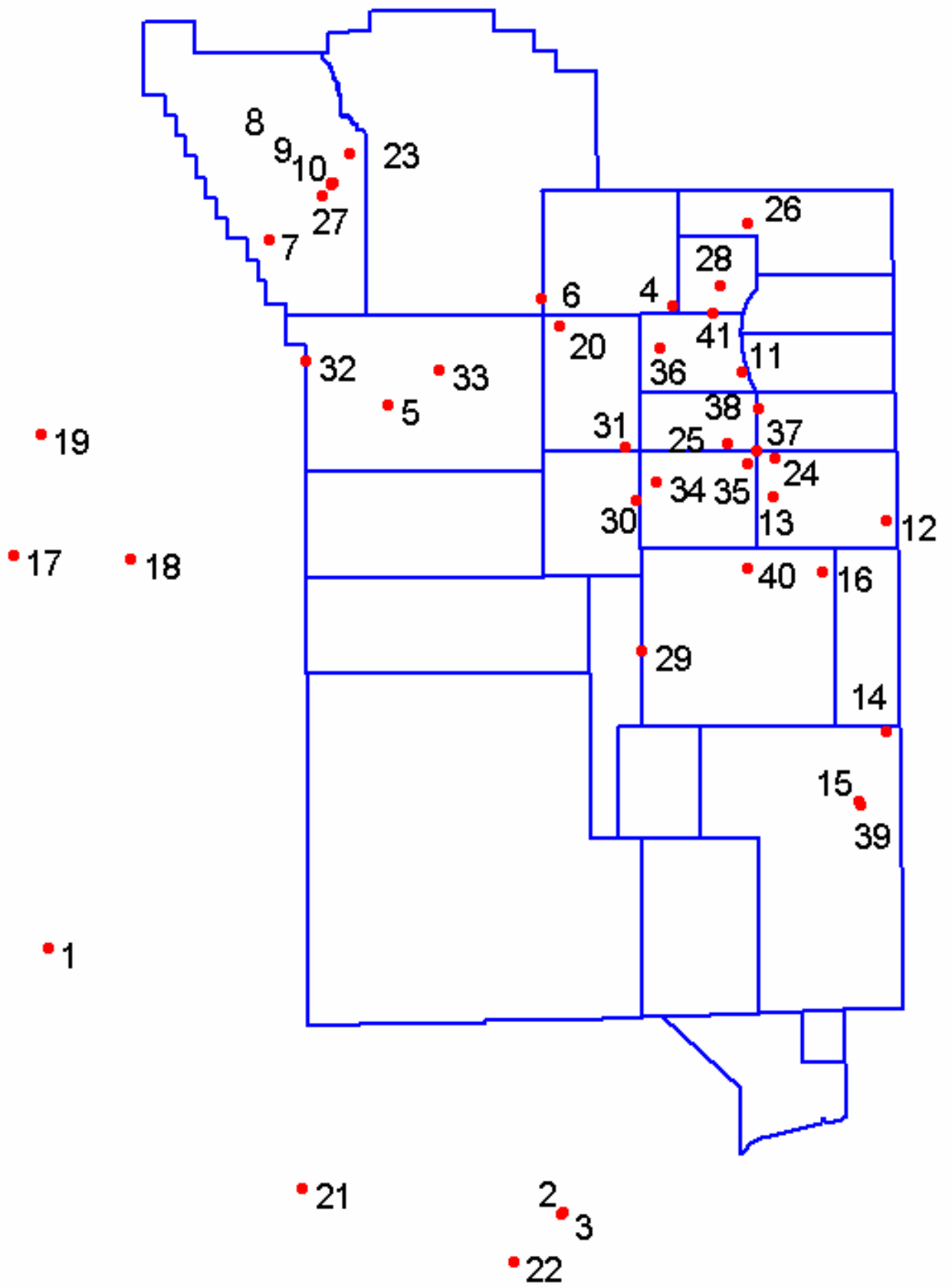

Figure 49. Location of boreholes investigated in this study. 


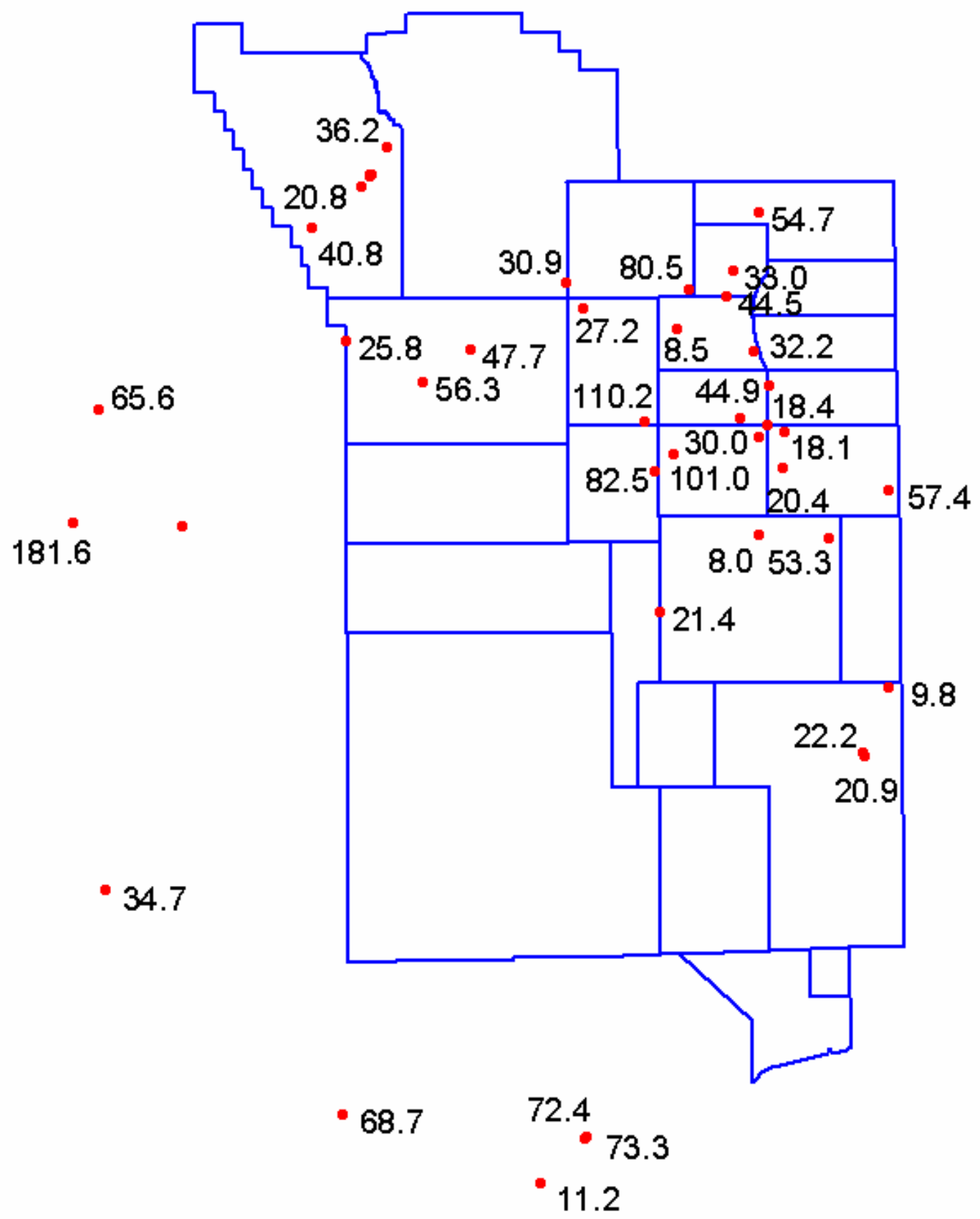

Figure 50. Heat flow values determined from wells investigated in this study. 
Table 5. Heat flow values $\left(\mathrm{mW} \mathrm{m}^{-2}\right)$ for boreholes investigated in this study.

\begin{tabular}{cccccc}
\hline Number & Name & Heat Flow & Number & Name & Heat Flow \\
\hline 1 & ASH-B & 34.7 & 21 & LWS-A & 68.7 \\
2 & ATH1 & 73.3 & 22 & MSH-C & 11.2 \\
3 & ATH2 & 72.4 & 23 & PM-1 & 36.2 \\
4 & ER-12-2 & 80.5 & 24 & TW-7 & 18.1 \\
5 & ER-18-2 & 56.3 & 25 & TW-D & n/a \\
6 & ER-19-1 & 30.9 & 26 & U-15k & 54.7 \\
7 & ER-20-5\#1 & 40.8 & 27 & U-20 Water Well & 20.8 \\
8 & ER-20-6\#1 & n/a & 28 & UE-10j & 33 \\
9 & ER-20-6\#2 & n/a & 29 & UE-14b & 21.4 \\
10 & ER-20-6\#3 & n/a & 30 & UE-16f & 82.5 \\
11 & ER-2-1 & 32.2 & 31 & UE-17a & 110.2 \\
12 & ER-3-1-2 & 57.4 & 32 & UE-18r & 25.8 \\
13 & ER-3-2-2 & 20.4 & 33 & UE-18t & 47.7 \\
14 & ER-5-3\#2 & 9.8 & 34 & UE-1l & 101 \\
15 & ER-5-4\#2 & 22.2 & 35 & UE-1q & 30 \\
16 & ER-6-1 & 53.3 & 36 & UE-2ce & 8.5 \\
17 & ER-OV-03a2 & 181.6 & 37 & UE-3e\#4 & 18.4 \\
18 & ER-OV-03c & n/a & 38 & UE-4t-2 & 44.9 \\
19 & ER-OV-06a & 65.6 & 39 & UE-5n & 20.9 \\
20 & HTH-1 & 27.2 & 40 & UE-6d & 8 \\
& & & 41 & Water Well 2 & 44.5 \\
\hline
\end{tabular}

Sass and Lachenbruch (1982) calculated a heat flow value of $56 \mathrm{~mW} \mathrm{~m}^{-2}$ (Table 1) for borehole U-15k; the current investigation estimated a heat flow value for U-15k of $54.7 \mathrm{~mW} \mathrm{~m}^{-2}$. These heat flow values for U-15k are in excellent agreement. U-15k is drilled within an extremely tight granite where fluid flow within the borehole would not be expected to affect the temperature profile from the borehole.

\section{Heat Flow in the Carbonate Aquifer}

In this study, heat flow values were obtained in the Paleozoic carbonate aquifer in six boreholes, ATH1, ATH2, UE-1q, UE-2ce, Water Well 2, and UE-10j. In UE-1q, heat flow values in the carbonate aquifer and overlying volcanic tuff aquitard were remarkably similar, approximately $30 \mathrm{~mW} \mathrm{~m}^{-2}$, indicating the absence of advection of heat by groundwater flow within the aquifer. Water Well 2 displayed the same sharp break in gradient between the carbonate aquifer and the overlying tuffaceous sediment. Within the tuffaceous sediment, the heat flow value was determined to be $44.5 \mathrm{~mW} \mathrm{~m}^{-2}$. The thermal gradient below the break in gradient is extremely linear, indicating a lack of vertical fluid movement. Using the geothermal gradient across the carbonate interval penetrated by the borehole, a heat flow value of $34.5 \mathrm{~mW} \mathrm{~m}^{-2}$ was calculated for the carbonate aquifer. (This heat flow is comparable to that calculated for UE-10j at $33.5 \mathrm{~mW} \mathrm{~m}^{-2}$, located about 2,200 $\mathrm{m}$ to the northeast of Water Well 2.) The lower heat flow within the carbonate interval at Water Well 2, compared to the overlying tuffs, may be due to vertical fluid movement within the borehole, or due to an error in the estimation of thermal conductivity for the tuff or carbonate units. It may also be possible that horizontal flow, with the associated advection and mixing of heat energy, is present in the 
carbonate aquifer, effectively lowering the apparent thermal conductivity of the carbonate aquifer in both Water Well 2 and UE-10j.

In boreholes ATH1 and ATH2, the average heat flow in the overlying alluvium and tuff units was determined to be approximately $73 \mathrm{~mW} \mathrm{~m}^{-2}$; however, within the carbonate aquifer, the calculated heat flow values, given the vertical to slightly negative thermal gradients, would have been near zero $\mathrm{mW} \mathrm{m}^{-2}$. The most likely explanation for the extremely low apparent heat flow values in the carbonate aquifer at ATH1 and ATH2 is the presence of significant horizontal flow within the aquifer, with mixing and dispersion of heat produced by the groundwater movement acting to effectively increase the thermal conductivity of the carbonate unit. The negative thermal gradient seen in borehole ATH2 may be the result of significant advective heat transport due to groundwater flow actually reducing the temperature of the carbonate units penetrated by the wellbore. This concept appears to be supported by the difference in average temperatures measured within the carbonate units within the two boreholes, where the average temperature within the carbonate units in borehole ATH1 is about $1.5^{\circ} \mathrm{C}$ warmer than within the carbonate units in borehole ATH2.

The heat flow value calculated for the carbonate aquifer at UE-2ce was also extremely low $\left(8.5 \mathrm{~mW} \mathrm{~m}^{-2}\right)$, indicating the presence of groundwater flow within the carbonate aquifer penetrated by the borehole.

\section{Heat Flow and Low Thermal Conductivity Lithologies}

Anomalously high heat flow values were estimated in boreholes UE-1l (Figure 17), UE-16f (Figure 18), UE-17a (Figure 19), and ER-12-2 (Figure 41). The first three of these boreholes are located in the vicinity of Syncline Ridge on the western edge of Yucca Flat and penetrate argillites and quartzites. Unlike vast portions of the NTS, the Syncline Ridge area does not contain volcanic rocks and there is very little alluvium. A likely explanation for the high heat flow values estimated in the area around Syncline Ridge is that heat flow is refracted away from areas covered with lower thermal conductivity alluvium and volcanic units and channeled towards the area near Syncline Ridge, where higher thermal conductivity quartzites, argillites, and carbonate units overlie basement rocks. ER-12-2 also penetrates primarily quartzites, argillites, and carbonate units, which overlie basement rocks. The next highest heat flow value from a borehole on the NTS was measured at ER-3-1 on the extreme east side of the NTS. ER-3-1 is located in an area with only approximately $275 \mathrm{~m}$ of alluvium and tuff units overlying Paleozoic lithologies. Figure 51 illustrates this distribution of heat flow in and around Yucca Flat. Heat flow values determined from boreholes UE-2ce, UE-10j, and UE-4t were omitted from Figure 51 because they were likely affected by groundwater flow or nearby nuclear testing and do not represent accurate heat flow values.

\section{Spatial Variability of Heat Flow Values}

The heat flow values calculated for boreholes located on Pahute and Buckboard mesas varied greatly. ER-18-2, UE-18t, ER-20-5\#2, and PM-1 were determined to be 56.3, 47.7, 40.8, and 36.2, respectively. However, U-20 Water Well and UE-18r yielded values of 20.8 and 25.8, respectively. As noted earlier, the low heat flow value determined for U-20 Water Well may be an effect of the use of the well for water supply, or indicative of horizontal flow within the lava lithology, or possibly annular flow behind the cased portion of the borehole. The temperature 


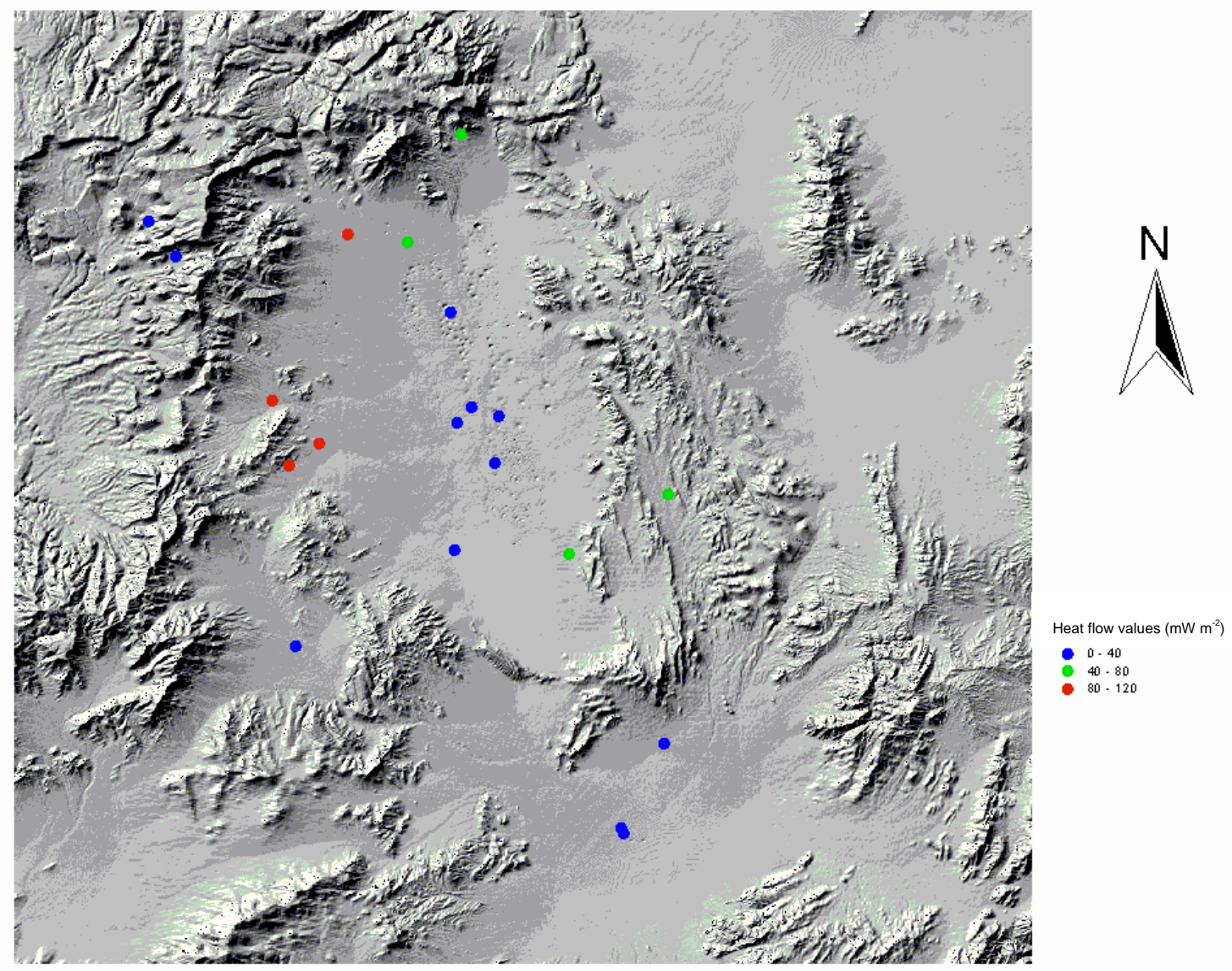

Figure 51. Heat flow values in and around Yucca Flat at the NTS.

profile present in UE-18r below the casing indicated significant downward fluid movement within the borehole. If downward flow were present within the volcanic units in this portion of the NTS, this would explain the somewhat lower heat flow values estimated at UE-18r as compared to PM-1, ER-20-5\#2, ER-18-2, and UE-18t.

The two boreholes located southwest of Rainier Mesa, HTH-1 and ER-19-1, yielded similar heat flow values of 27.2 and $30.9 \mathrm{~mW} \mathrm{~m}^{-2}$, respectively,

The lowest heat flows, which did not appear to be affected by groundwater flow, were estimated in boreholes UE-6d, TW-7, UE-3e\#4, ER-3-2, UE-14b, UE-5n, ER-5-3\#2 and $E^{-5} 5-4 \# 2$, with values of 8.0, 18.1, 18.4, 20.4, 21.4, 20.9, 9.8, and $22.2 \mathrm{~mW} \mathrm{~m}^{-2}$, respectively. The low heat flow value calculated for borehole UE-5n is easily explained by the borehole's location in central Frenchman Flat. The depth to the carbonate aquifer beneath Frenchman Flat in the vicinity of UE-5n is estimated to be greater than approximately 2,000 m below ground surface (IT Corp., 2001). The thick section of low thermal conductivity tuffs and alluvium overlying the carbonate aquifer would tend to deflect heat away from the center of Frenchman Flat and towards the edges of the basin. TW-7 and UE-3e\#4, although located only 2,240 m and $1,283 \mathrm{~m}$, respectively, east-northeast of UE-1q, displayed heat flow values of 19.6 and $19.4 \mathrm{~mW} \mathrm{~m}^{-2}$, respectively, while the heat flow value at UE-1q was calculated to be 
approximately $30 \mathrm{~mW} \mathrm{~m}^{-2}$. Phelps and McKee (1999) examined gravity data to determine the surface elevation of the carbonate aquifer in Yucca Flat. Their results indicated that approximately 800-m-thicker sections of tuffs and alluvium overly the carbonate aquifer in the vicinity of TW-7, UE-3e\#4, and ER-3-2 relative to the location of UE-1q. UE-6d is located in western Yucca Flat, where thick sections of alluvial (1,161 m at UE-6d) and volcanic units would be expected. UE-14b, with a heat flow value of $22.3 \mathrm{~mW} \mathrm{~m}^{-2}$, is also located in an area of relatively thick alluvial and volcanic sections.

One of the lowest heat flow values for boreholes in the investigation was ER-5-3\#2, with a calculated heat flow value of $9.8 \mathrm{~mW} \mathrm{~m}^{-2}$. Several factors may contribute to the low heat flow determined for ER-5-3\#2. Over 1,400 m of low thermal conductivity alluvial and volcanic lithologies overlie the Paleozoic units penetrated by ER-5-3\#2. Additionally, groundwater flow in the alluvial aquifer (with the associated mixing and lowering of the apparent thermal conductivity) may have the effect of reducing the measured geothermal gradient, producing a low heat flow value. Additionally, ER-5-3\#2 is located near Nye Canyon in the north-east portion of Frenchman Flat and downward fluid movement through recharge could possibly also have the effect of lowering the apparent heat flow at ER-5-3\#2.

Temperature profiles from the ER-OV boreholes located in Oasis Valley west of the NTS are interesting because they present an opportunity to observe a shallow groundwater temperature regime. Examination of the temperature profile from ER-OV-06a yielded heat flow data that qualitatively indicates discharge from the shallow aquifer in Oasis Valley. With additional data, such as a record of temperature variation with depth for a period of a year or more, it should be possible to quantify the vertical groundwater flux rate at this location. Using a simple numerical model, a vertical groundwater flow rate of approximately $-0.16 \mathrm{~m} / \mathrm{yr}$ was determined from the degree of curvature observed in the temperature profile obtained from ER-OV-3c.

\section{SUMMARY}

In this investigation, 145 previously recorded temperature logs from 63 boreholes on or near the NTS were examined. Thirteen of these temperature logs were determined to be suitable for the determination of heat flow values. Additionally, 36 new temperature profiles were obtained in the field, either to validate existing temperature profiles, or to provide additional temperature profiles for heat flow determination. Of these, 23 boreholes were found to have temperature profiles suitable for the determination of additional heat flow values from one or more intervals within the boreholes. Comparison of the previously existing and relogged temperature profiles, in general, displayed excellent correlations, and demonstrated the usefulness and reliability of existing temperature profiles from the NTS. Heat flow values for intervals contained within the 36 boreholes from which values could be determined ranged from a low of $8.0 \mathrm{~mW} \mathrm{~m}^{-2}$ to a high of $181.6 \mathrm{~mW} \mathrm{~m}^{-2}$.

Vertical variations in heat flow values, within individual boreholes, were readily explained by the advection of heat by groundwater flow. Horizontal consistencies and variations in heat flow values between various boreholes were dependent upon the geologic setting of the borehole, and the effect of vertical fluid movement.

Temperature profiles are extremely easy and inexpensive to obtain. Considerable hydrologic information can be determined from the examination of a single temperature profile; 
however, if sufficient spatially distributed heat flow values are obtained, a heat transport model of the NTS could be used to reduce the uncertainty of nonisothermal hydrologic models.

\section{REFERENCES}

Auld, M.J., 1948. Temperature gradients for convection in well models. Journal of Applied Physics 19:218.

Beck, A.E., 1992. Inferring past climate change from subsurface temperature profiles: Some problems and methods. Palaeogeogr. Palaeoclimatol. Palaeoecol. (Global Planet. Change Sect.) 98:73-80.

Beltrami, H. and A.E. Taylor, 1995. Records of climatic change in the Canadian Arctic: Towards calibrating oxygen isotope data with geothermal data. Global and Planetary Change 11:127138.

Birch, F., 1947. Temperature and heat flow in a well near Colorado Springs, Am. J. Sci. 245:733753.

Bredehoeft, J.D. and I.S. Papadopulos. 1965. Rates of vertical groundwater movement estimated from earth's thermal profile. Water Resources Research 1:325-328.

Bullard, E.C., 1939. Heat flow in South Africa. Proc. R. Soc. London A173(995):474-502.

Chapman, D.S., M.D. Clement and C.W. Mase, 1981. Thermal regime of the Escalante Desert, Utah, with an analysis of the Newcastle Geothermal System. J. Geophys. Res. 86(B12):11,735-11,746.

Chisholm, T. J. and D.S. Chapman, 1992. Climate change inferred from borehole temperatures: An example from western Utah. J. Geophys. Res. 97:14155-14176.

Deming, D. and R.A. Borel, 1995. Evidence for climatic warming in north-central Oklahoma from analysis of borehole temperatures. J. Geophys. Res. 100:22,017-22,032.

DeVries, D.A., 1963. Thermal properties of soils. In van Wijk, W.R. (ed.), Physics of Plant Envirnonment. North-Holland, Amsterdam.

Diment, W.H., 1967. Thermal regime of a large diameter borehole: Instability of the water column and comparison of air- and water-filled conditions. Geophysics 32(4):720-726.

Fridrich, C.J., W.W. Dudley and J.S. Stuckless, 1994. Hydrogeologic analysis of the saturatedzone ground-water system, under Yucca Mountain, Nevada, Journal of Hydrology 154:133168.

Gillespie, D., S. Hokett and C. Russell. 1995. Estimation of moisture flux rates in nuclear subsidence craters using the annual temperature pulse. Presentation at Geological Society of America Conference - 1995, New Orleans, Louisiana.

Gillespie, D., 2002. Temperature Data Evaluation. Desert Research Institute Publication No. 45194, DOE/NV/13609-22.

Gillespie, D. and C. Russell. 2003. Temperature Profiles and Hydrologic Implications from the Nevada Test Site Area. Presentation at American Geophysical Union Conference - 2003, San Francisco, California.

Gretener, P.E., 1967. On the thermal instability of large diameter wells - an observational report. Geophysics 32(4):727-738. 
Hales, A.L., 1937. Convection currents in geysers. Monthly Notices of the Royal Astronomical Society, Geophysics Supplement, 4:122-131.

Huang, S., H.N. Pollack and P.Y. Shen, 2000. Temperature trends over the past five centuries reconstructed from borehole temperatures. Nature 403:756-758.

Hunt, J.M., M.D. Lewan and R.J. Hennet, 1991. Modeling oil generation with time-temperature index graphs based on the Arrhenius equation. AAPG Bulletin 75(4):795-807.

IT Corporation, 2001. Addendum to the Frenchman Flat Hydrogeologic Investigation Wells Drilling and Completion Criteria, Revision No.: 1, ITLV/13052-094-REV. 1-ADD.

Johnston, G.H., B. Ladanyi, N.R. Morgenstern and E. Penner, 1981. Engineering Characteristics of Frozen and Thawing Soils. Permafrost Engineering Design and Construction. Edited by Johnston, G.H. John Wiley \& Sons.

Lazniak, R. J., J. C. Cole, D. A. Sawyer and D. A. Trudeau, 1996. Summary of Hydrologic Controls on Groundwater Flow at the Nevada Test Site, Nye County, Nevada. U. S. Geological Survey - Water Resources Investigations Report 96-4109. 59 p.

Lachenbruch, A.H., M.L. Sorey, R.E. Lewis and J.H. Sass, 1976. The near-surface hydrothermal regime of Long Valley Caldera. J. Geophys. Res. 81:763-768.

Lopatin, N.V., 1976. The influence of temperature and geologic time on the catagenetic processes of coalification and petroleum and gas formation. In Isseledovaniya Organicheskogo Veshchestva Sovremennykh i Iskopayemykh Osakdov (Study of Organic Matter in Recent and Old Sediments), pp.361-6. Moscow: Nauka Press.

Lowrie, A., R. Hamiter, M.A. Fogarty, T. Orsi and I. Lerche, 1996. Thermal and timetemperature index (TTI) patterns during geologic evolution of North and central Gulf of Mexico. In AAPG Bulletin, 80(9), Abstracts of Meeting: AAPG Gulf Coast Association of Geological Societies, San Antonio, Texas, United States, October 2-4, 1996, p.1508. Tulsa, Oklahoma: American Association of Petroleum Geologists.

Lyles, B.F., W.A. McKay, J.B. Chapman and S.W. Tyler, 1991. Hydrogeologic Characterization of Wells HTH-1, UE18r, UE6e, and HTH-3, Nevada Test Site, Desert Research Institute Publication No. 45087, DOE/NV/10845-08.

Phelps G.A. and E.H. McKee, 1999. High-angle faults in the basement of Yucca Flat, Nevada Test Site, Nevada, based on analysis of a constrained gravity inversion surface: U.S. Geological Survey Open-File Report 99-383, 11 p.

Pollack, H.N., 1993. Climate change inferred from borehole temperatures. Palaeogeogr. Palaeoclimatol. Palaeoecol. (Global Planet. Change Sect.) 99:173-179.

Pollack, H.N., S.J. Hurter and J.R. Johnson, 1993. Heat flow from the Earth's interior: Analysis of the global data set. Reviews of Geophysics 31(3):267-280.

Pottorff, E.J., S.J. Erikson and M.E. Campana, 1987. Hydrologic Utility of Borehole Temperatures in Areas 19 and 20, Pahute Mesa, Nevada Test Site. Desert Research Institute Publication \#45060.

Ramey, H.J., 1962. Wellbore heat transmission. Journal of Petroleum Technology 14:427-435. 
Reiter, M., A.J. Mansure and C. Shearer, 1979. Geothermal characteristics of the Rio Grande Rift within the southern Rocky Mountain complex, In Rio Grande Rift: Tectonics and Magnetism, R.E. Reicker (ed.), pp. 253-267, AGU, Washington, D.C.

Sass, J.H., A.H. Lachenbruch and C.W. Mase, 1980. Analysis of thermal data from drill holes UE25a-3 and UE25a-1, Calico Hills and Yucca Mountain, Nevada Test Site. U.S. Geological Survey Open-File Report 80-826, 25 p.

Sass, J.H. and A.H. Lachenbruch, 1982. Preliminary interpretation of thermal data from the Nevada Test Site. U.S. Geological Survey Open-File Report 82-973, 30 p.

Sass, J.H., A.H. Lachenbruch, W.W. Dudley, S.S. Priest and R.J. Munroe, 1987. Temperature, thermal conductivity, and heat flow near Yucca Mountain, Nevada: Some tectonic and hydrologic implications. U.S. Geological Survey Open-File Report, 87-649, 118 p.

Smith, L. and D.S. Chapman, 1983. On the thermal effects of groundwater flow. 1. Regional scale systems, J. Geophys. Res. 88(B1):593-608.

Urban, T.T., W.H. Diment and M. Nathenson, 1978. East Mesa geothermal anomaly, Imperial County, California: Significance of temperature in a deep drill hole near thermal equilibrium. In Geothermal Energy: A Novelty Becomes Resource (Transactions of Meeting, Hilo, Hawaii, July 25-27), vol. 2(2), ed. J. Combs, pp. 667-670. Davis, California: Geothermal Resource Council.

Van Orstrand, C.E, 1934. Temperature gradients, In Problems of Petroleum Geology, pp. 9891021. American Association of Petroleum Geologists, Tulsa, Okla.

Whiteford, P., 1993. Evaluation of past climate using borehole temperature measurements. Weather and Climate 13:3-8.

Wisian, K.W., D.D. Blackwell, S. Bellani, J.A. Henfling, R.A. Normann, P.C. Lysne, A. Forster and J. Schrotter, 1998. Field comparison of conventional and new technology temperature logging systems. Geothermics 27(2):131-141.

Woodbury, A.D. and L. Smith, 1985. On the thermal effects of three-dimensional groundwater flow. J. Geophys. Res. 90(B1):795-767.

Wright, J.A. and K.E. Louden, 1989. CRC Handbook of Sea Floor Heat Flow. CRC Press, Inc., Boca Raton, FL, p. 197. 


\section{DISTRIBUTION}

Bob Bangerter

Environmental Restoration Division

Nevada Site Office

National Nuclear Security Administration

U.S. Department of Energy

P.O. Box 98518

Las Vegas, NV 89193-8518

Naomi Becker

Los Alamos National Laboratory

P.O. 1663, EES-6, MSF-665

Los Alamos, NM 87545

Jeff Daniels

Lawrence Livermore National Laboratory

P.O. Box 808 M/S J514 CST-7

Livermore, CA 94551

Barbara Deshler

Stoller-Navarro Joint Venture

7710 W. Cheyenne Avenue

Las Vegas, NV 89129

Bruce Hurley

Hydrology Program Manager

Environment, Safety \& Health Division

Nevada Site Office

National Nuclear Security Administration

U.S. Department of Energy

P.O. Box 98518

Las Vegas, NV 89193-8518

Marjory Jones

Division of Hydrologic Sciences

Desert Research Institute

2215 Ragio Parkway

Reno, NV 89512-1095

John McCord

Stoller-Navarro Joint Venture

7710 W. Cheyenne Avenue

Las Vegas, NV 89129

Ken Ortego

Bechtel Nevada

P.O. Box 98521

Las Vegas, NV 89193-8521
Gayle Pawloski

Lawrence Livermore National Laboratory

P.O. Box 808 L-221

Livermore, CA 94551

Tim Rose

Lawrence Livermore National Laboratory

P.O. Box 808, M/S L-231

Livermore, CA 94551

Chuck Russell

Division of Hydrologic Sciences

Desert Research Institute

755 E. Flamingo Road

Las Vegas, NV 89119-7363

Peter Sanders

Environmental Restoration Division

Nevada Site Office

National Nuclear Security Administration

U.S. Department of Energy

P.O. Box 98518

Las Vegas, NV 89193-8518

David Shafer

Division of Hydrologic Sciences

Desert Research Institute

755 E. Flamingo Road

Las Vegas, NV 89119-7363

Bonnie Thompson

Water Resources, Nevada District

U.S. Geological Survey

160 N. Stephanie Street

Henderson, NV 89074

Martha Youngblood, Contracting Officer

Acquisition Department

Office of Business Services

NNSA Service Center

U.S. Department of Energy

P.O. Box 5400

Albuquerque, NM 87185-5400

Nevada State Library and Archives

State Publications

100 North Stewart Street

Carson City, NV 89701-4285 
Archives

Getchell Library

University of Nevada, Reno

DeLaMare Library/262

University of Nevada, Reno

Document Section, Library

University of Nevada, Las Vegas

4505 Maryland Parkway

Las Vegas, NV 89154

Stoller-Navarro Joint Venture

P.O. Box 93838

Bldg. B-1, M/S 439

Las Vegas, NV 89193-3838

ATTN: Toni Miller, M/S 439

Library

Southern Nevada Science Center

Desert Research Institute

755 E. Flaming Road

Las Vegas, NV 89119-7363
Public Reading Facility

c/o Nuclear Testing Archive

Nevada Site Office

National Nuclear Security Administration

U.S. Department of Energy

P.O. Box 98521, M/S 400

Las Vegas, NV 89193-8521

Technical Library

Nevada Site Office

National Nuclear Security Administration

U.S. Department of Energy

P.O. Box 98518

Las Vegas, NV 89193-8518

Office of Scientific and Technical Information

U.S. Department of Energy

P.O. Box 62

Oak Ridge, TN 37831-9939

(electronic copy 